\title{
SCENARIO DEVELOPMENT TO SUPPORT STRATEGIC PLANNING IN THE SOUTH AFRICAN TABLE GRAPE INDUSTRY
}

\author{
By
}

\section{SIFISO NTOMBELA}

Thesis presented in partial fulfilment of the requirements for the degree of Master of Science in Agriculture (Agricultural Economics) at the Stellenbosch University

Department of Agricultural Economics

Faculty of AgriSciences

Supervisor: Prof Theo Kleynhans

March 2010 


\section{DECLARATION}

By submitting this thesis electronically, I declare that the entirety of the work contained therein is my own, original work, that I am the authorship owner thereof (unless to the extent explicitly otherwise stated) and that I have not previously in its entirety or in part submitted it for obtaining any qualification.

March 2010

Copyright $@ 2010$ Stellenbosch University

All rights reserved 


\section{SUMMARY}

The South African table grape industry has evolved significantly in the last two decades. Ever improving supply chain technologies, post-harvest technology innovation, and more efficient production inputs have all stimulated the production of table grapes in all five South African production regions. While the industry in general is well developed, from the late 1990s the competitiveness status of the South African table grape industry has been negative as far as international competitiveness is rated. Prior to this, from 1961 to 1998, the industry had recorded positive trends in competitiveness. The recent decline, from as early as the 2000 s, in the competitiveness of the industry can be attributed to rising competition from alternate Southern Hemisphere suppliers, increasing production costs and export costs, as well as inadequate market diversification.

As a result of its negative competitiveness status, the table grape industry wants to diversify its export markets in order to improve and protect the industry's position in the global table grape markets. The objective of this study is to investigate the viability of specific export market diversification scenarios. The aim is to evaluate the potential impact on the table grape industry if export volumes were to be relocated from traditional to emerging markets, and the potential risk if the industry were to maintain the current market distribution. The study developed a deterministic farm-level model based on accounting principles as a tool for simulating and analysing the impact of changes in markets on the financial viability of farms under different scenarios. A scenario development process is adopted in this study as it offers the possibility of integrating various kinds of data in a consistent manner, and it can represent the views and expectations of several stakeholders simultaneously.

Three scenarios were developed: (i) Scenario 1 presents the continuation of current market distributions (i.e. $85 \%$ of South African exports are marketed in Europe and another $15 \%$ are distributed to other global markets); (ii) Scenario 2A depicts a situation where export volumes are slowly redistributed to emerging markets; and (iii) Scenario 2B presents a situation where export volumes are rapidly redistributed to emerging markets. The targets for both Scenarios 2A and 2B are to market $60 \%$ of South African exports to Europe and $40 \%$ to other global markets. Scenarios $2 \mathrm{~A}$ and $2 \mathrm{~B}$ are driven by similar factors, including improving industry information, globalisation, increasing competition, and table grape prices. 
An analysis of factors shaping the table grape export sector shows that the industry can no longer afford to send large export quantities predominantly to its traditional markets, due to increasing competition and diminishing market prices. Furthermore, the analysis shows that continuing with the current market diversification will have a negative impact on the industry, as farm returns, employment and farm units will decline under this scenario. The results suggest that the industry would be better off if export volumes were redistributed away from Europe to other markets. 


\section{OPSOMMING}

Gedurende die laaste twee dekades het die Suid Afrikaanse Tafeldruif Industrie met rasse skrede vooruitgegaan. Dit kan grootliks toegeskryf word aan verbeterde tegnologiese ontwikkeling en innovasie in die voorsieningsketting en na-oes tegnologie arenas, asook aan meer doeltreffende produksie insette wat produksie toenames in al vyf die Suid Afrikaanse produksie areas gestimuleer het. Alhoewel die industrie relatief goed ontwikkeld was sedert sy ontstaan, was die kompeterende status daarvan meestal negatief sedert die 1990's, gemeet aan internasionale kompetisie. Daar was egter tussen 1961 en 1998 ook positiewe mededinging tendense. Die onlangse verlaagde vlakke van mededingendheid van die industrie (veral sedert die vroeë 2000's) kan toegeskryf word aan verhoogde kompetisie vanaf ander Suidelike Halfrond verskaffers, verhoogde produksie- en uitvoerkoste, asook aan onvoldoende mark diversifisering.

As gevolg van die negatiewe mededingendheid status, wil die tafeldruif industrie sy uitvoer markte diversifiseer om te verseker dat die industrie sy posisie in die globale tafeldruif mark kan beskerm. Die doel van hierdie studie is dus om die lewensvatbaarheid van spesifieke uitvoer mark diversifisering scenario's te ondersoek. Daarmee saam is die potensiële impak op die industrie ook bepaal vir (a) ' $n$ hoë persentasie uitvoer volumes wat verskuif vanaf tradisionele markte na ontluikende market, of (b) wat die risiko sal wees indien die huidige markverspreiding vlakke behou word. Die studie ontwikkel ' $n$ deterministiese plaasvlak model, gebaseer op rekeningkundige beginsels, om as hulpmiddel te dien vir die simulering en analise van die impak van verandering van teikenmarkte op die fnansiële lewensvatbaarheid van plase onder verskillende omstandighede. ' $\mathrm{n}$ Scenario intwikkelings proses word in hierdie studie aangeneem aangesien dit toelaat vir die integrasie van verskillende tipes data op ' $n$ eenvormige wyse, terwyl dit ook die sieninge en verwagtinge van verskeie rolspelers terselfdertyd kan verteenwoordig.

Drie scenario's word ontwikkel naamlik (i) Scenario 1: Dit verteenwoordig die huidige mark verspreiding (85\% van Suid Afrikaanse uitvoere word in Europa bemark terwyl 15\% versprei word na ander globale markte); (ii) Scenario 2A: Hier word die situasie uitgebeeld indien uitvoer volumes stadig herverdeel word na ontluikende markte; en (iii) Scenario 2B: Hier word die situasie uitgebeeld indien uitvoer volumes vinnig herverdeel word na ontluikende markte. 
Die teikens vir beide Scenario 2A en 2B is om 60\% van die Suid Afrikaanse uitvoere in Europa te bemark en $40 \%$ in ander globale markte. Beide scenario's word deur dieselfde faktore gestu wat onder andere verbeterde industrie inligting, globalisering, verhoogde kompetisie en produk pryse insluit.

' $n$ Ontleding van die vormende faktore van die tafeldruif uitvoer sektor toon dat die industrie nie langer kan bekostig om hoë uitvoer volumes na die tradisionele markte te stuur nie, as gevolg van sterker kompetisie en krimpende markpryse. Die ontleding toon ook verder dat, indien voortgegaan word met die huidige mark diversifiserings model, die industrie negatief beïnvloed sal word in terme van verlaagde plaas inkomste, werkverskaffing en die aantal boerdery eenhede. Die uitslae dui dus daarop dat die industrie beter daaraan toe sal wees indien die huidige uitvoer volumes herverdeel kan word na ander (nie-Europese) markte. 


\section{ACKNOWLEDGEMENTS}

First and foremost, I would like to thank God Almighty for his love and grace, for without him none of this will be possible.

I would like to use this opportunity to acknowledge and express my appreciation to the following people who made valuable contributions to the completion of this thesis.

Prof T Kleynhans, thank you for guidance, time and wisdom you have given me throughout the preparation of this thesis. It was a privilege to have you as my study leader.

Elaine Alexander, thank you for the wisdom and leadership you have given me since I joined SATI. Thank you for the valuable insight you have taught me in all aspects of life.

Willem Hoffmann, thank you for the guidance and support in developing the models.

Pieter Raath, thank you for academic support and encouraging me to study viticulture (table grapes) as well as your willingness to help.

SATI team, thank you for your endless motivational support that you have given me at every stage of this thesis.

SATI executive management, for funding of this study and liberty to use industry data.

Table grape exporters and producers, for support during gathering of study data.

Tshego Oshupeng, a special thank for encouragement, interest and love.

My parents, family members and friends, for your support, guidance, love and all the sacrifices they made, that mean the world to me. I therefore dedicate this study to my aunt Samukelisiwe Ntombela Nzama. 


\section{Table of Contents}

\section{CHAPTER 1 \\ INTRODUCTION}

1.1. Introduction 1

1.2. History of South African export industry 2

1.3. The rise of other suppliers to Europe 3

1.4. The emerging need for market diversification 4

1.5. Study objectives and expected outcomes 6

1.6. Thesis structure 8

\section{CHAPTER 2}

\section{LITERATURE REVIEW}

2.1. Introduction 9

2.2. Three schools of strategic management thinking 9

2.2.1. The Rationalistic Paradigm 9

2.2.2. The Evolutionary Paradigm 10

$\begin{array}{ll}\text { 2.2.3. The Processual Paradigm } & 10\end{array}$

2.3. Definition of scenario 11

2.4. Origin of scenarios 12

$\begin{array}{ll}\text { 2.5. Evolution of scenarios } & 12\end{array}$

2.6. Nature and principles of scenarios 13

$\begin{array}{ll}\text { 2.7. Types of scenarios } & 14\end{array}$

2.8. Functions of scenarios $\quad 15$

2.9. Scenario development process 17

$\begin{array}{ll}\text { 2.10. Criteria for the evaluation of scenarios } & 20\end{array}$

2.11.Pitfalls of scenario development 21

2.12. Scenario development in agricultural sector 23

2.13. Scenario development in South African agricultural sector 27

2.14.Conclusions 29 


\section{CHAPTER 3}

BACKGROUND INFORMATION ON FARM MODELLING AND SIMULATION

3.1. Introduction 30

3.2. Definition of modeling and simulation $\quad 30$

$\begin{array}{ll}3.3 \text { The process of simulation } & 30\end{array}$

3.4. Farm simulation model: types and purpose of modeling 31

3.5. Farm simulation model: approaches of simulation 32

3.5.1. The normative approach $\quad 32$

3.5.2. The positive approach 33

3.6. Conclusions 34

\section{CHAPTER 4 \\ METHODOLOGY}

4.1. Introduction 35

4.2. Study method 36

4.3. Models used to determine farm profitability 39

4.3.1. Farm-level model $\quad 39$

4.3.1.1. Description of typical farms used in the models 39

4.3.1.2. Type of data used and data collection process $\quad 40$

4.3.1.3. Assumptions in the farm-level model 41

4.3.1.4. Simulation process and structure of the farm-level model 43

4.3.2. Sector model 44

4.4. Conclusions 45

\section{CHAPTER 5}

\section{BACKGROUND INFORMATION IN THE TABLE GRAPE INDUSTRY}

5.1. Introduction 46

5.2. Description of South African production regions 47

5.3. The competitiveness status of the South African Agribusiness sector and the table grape industry $\quad 52$

5.3.1. Defining competitiveness 53

5.3.2. Measures of competitiveness 53

5.3.3. Competitiveness status of the South African Agribusiness sector $\quad 54$

5.3.4. Competitiveness status of the South African table grape industry 56 
5.4. Required changes to remain competitive global supplier 57

5.4.1. Sustainable viticulture practice 58

5.4.2. Improved food safety and quality standards $\quad 59$

$\begin{array}{ll}\text { 5.4.3. Research development } & 60\end{array}$

$\begin{array}{ll}\text { 5.5. Conclusions } & 60\end{array}$

\section{CHAPTER 6}

DESCRIPTION OF THE SELECTED MARKETS

$\begin{array}{lll}\text { 6.1. Introduction } & 61\end{array}$

6.2. Description of Europe market 61

6.2.1 European population and economic growth 62

6.2.2 Production and consumption in Europe $\quad 63$

6.2.3 Market barriers and challenges in European markets 65

6.2.4 Europe as trade partner to South Africa 67

6.2.4.1. Significance of Europe markets to South Africa 67

6.2.4.2. Intervention needed to improve competitiveness in Europe $\quad 68$

6.3. Description of the China market $\quad 69$

6.3.1 Overview of the Chinese market 69

$\begin{array}{ll}\text { 6.3.2 Competition and consumer preferences } & 70\end{array}$

6.3.3 Distribution channels and logistical constrains 72

6.3.4 Market barriers in Chinese market $\quad 72$

6.3.5 China as trade partner to South Africa 7

6.3.5.1. Significance of China market to South Africa 73

6.3.5.2. How China market differs from Europe market 74

6.4. Description of India market 75

6.4.1. Overview of the Indian horticulture sector 75

$\begin{array}{ll}\text { 6.4.2. Consumption and consumer preferences } & 77\end{array}$

6.4.3. Distribution channels and logistical constrains 78

$\begin{array}{ll}\text { 6.4.4. Other market barriers } & 78\end{array}$

6.4.5. India as trade partner to South Africa 79

6.4.5.1. Significance of India markets to South Africa 79

6.4.5.2. How India market differs from Europe market 80

$\begin{array}{ll}\text { 6.5. Conclusions } & 80\end{array}$ 


\section{CHAPTER 7}

NUMERICAL ESTIMATIONS AND SCENARIO OUTLINES

$\begin{array}{ll}\text { 7.1. Introduction } & 88\end{array}$

7.2. Scenario 1: Continuation of current situation 88

7.2.1. Sector model results under Scenario $1 \quad 89$

7.2.2. Farm-level model results under Scenario $1 \quad 90$

7.2.3. Implications in South African table grape industry 91

7.3. Scenario 2A: Slowly focusing on emerging markets 92

7.3.1. Sector model results under Scenario 2A 94

7.3.2. Farm-level model results under Scenario 2A 95

7.3.3. Implications in South African table grape industry 97

7.4. Scenario 2B:Rapidly focusing on emerging markets 97

7.4.1. Sector model results under Scenario 2B 99

7.4.2. Farm-level model results under Scenario 2B 100

7.4.3. Implications in South African table grape industry 101

$\begin{array}{ll}\text { 7.5. Summary } & 101\end{array}$

7.5.1. Sector model results: comparison of all three scenarios 101

7.5.2. Farm-level model results: comparison of thee scenarios 102

$\begin{array}{ll}\text { 7.6. Conclusions } & 106\end{array}$

CHAPTER 8

SUMMARY, CONCLUSSIONS AND RECOMANDATIONS

8.1. Summary 107

$\begin{array}{ll}\text { 8.2. Conclusions } & 110\end{array}$

$\begin{array}{ll}\text { 8.3. Recommendations } & 110\end{array}$

$\begin{array}{lr}\text { REFFERENCES } & 112\end{array}$

ANNEXURE A Attached

ANNEXURE B Attached

ANNEXURE C Attached

ANNEXURE D Attached 


\section{List of Figures}

Figure 1 South African grape exports: $1950-2010$

$\begin{array}{lll}\text { Figure } 2 \text { Eight steps of scenario development process } 20 & 20\end{array}$

$\begin{array}{lll}\text { Figure } 3 & \text { Forecasting, scenario and hope diagram } & 23\end{array}$

Figure 4 The order of implementation of simulating economic problems 33

$\begin{array}{lll}\text { Figure } 5 & \text { The basic matrix } & 40\end{array}$

Figure $6 \quad$ Structure of sector model for table grape industry 47

$\begin{array}{lll}\text { Figure } 7 & \text { Areas under Orange River region } & 51\end{array}$

Figure 8 Areas under Berg River region 52

Figure 9 Areas under Hex River region 53

Figure 10 Areas under Northern Province region 54

Figure 11 Areas under Olifants River region 55

Figure 12 An inverted $U$ shaped relationship between environmental degradation and per capita income: KUZNETS Curve 66

Figure 13 Table grape export market diversification outlook and industry price growth under Scenario 1

Figure 14 Realized export price growth for Western cape and Northern region farms under Scenario 1

Figure 15 Table grape export market diversification outlook and industry price growth under Scenario $2 \mathrm{~A}$

Figure 16 Realized export price growth for Western cape and Northern region farms under Scenario $2 \mathrm{~A}$

Figure 17 Table grape export market diversification outlook and industry price growth under Scenario 2B

Figure 18 Realized export price growth for Western Cape and Northern region farms under Scenario 2B

Figure 19 Industry export volumes and price growth under all scenarios 
Figure 20 Production strategies to produce high quality export grapes

Figure 21 Effect of replacement process in Western Cape farm under all scenarios 104

Figure 22 Effect of replacement process in Northern region farm under all scenarios

\section{List of Tables}

Table 1 Marco economic indicators for China, India and Europe 5

$\begin{array}{lll}\text { Table } 2 \text { Summary of the main functions of scenarios } & 16\end{array}$

Table 3 EU-15: macroeconomic indicators $\quad 61$

Table 4 Table grape consumption in Europe $\quad 62$

Table 5 Imports of table grapes by Europe 63

Table 6 South African table grape export to Europe 68

Table $7 \quad$ Chinese table grape production, consumption and import trends 71

$\begin{array}{lll}\text { Table } 8 & \text { Indian table grape area planted and production } & 77\end{array}$

Table 9 Market drivers and market characteristics of EU, China and India 84

Table 10 Farm-level results for Western Cape and Northern region farms under all scenarios 


\section{CHAPTER 1 \\ INTRODUCTION}

\subsection{Introduction}

From the inception of South African table grape exporting in 1886, when the first South African table grapes were exported to the United Kingdom, table grape exports to this market and the rest of Europe have developed into a large industry. The South African table grape industry is more than 120 years old today and currently exports just over 50 million cartons $(4.5 \mathrm{~kg})$ of table grapes per season to global markets (SATI, 2009). Over the last two decades, South Africa has managed to diversify only $15 \%$ of their total exports away from the UK and Continental Europe. The reason for this inadequate market diversity is that South Africa was colonised by Europeans, and together they have established a good trading partnership governed by the Trade, Development and Co-operation Agreement (TDCA). A second factor is the lack of understanding of emerging Eastern markets, which are economically, psychologically, environmentally and socially different from the traditional markets. Therefore, gaining an improved understanding of these differences will be a key tool in enhancing the producers' capacity to supply these markets successfully.

The constantly weakening exchange rate (strengthening of the euro and the pound against the rand) also adds to the reasons why South Africa prefers European markets. A South African exporter not only receives high returns when selling to European markets, but is also perceived as the preferred supplier of quality grapes (the country is now regarded as the preferred country of origin for quality and tasty grapes (SATI, 2009)). The other factor that encourages South African exports to the EU is that European markets are well developed and characterised by modern infrastructures, allowing rapid mobility of products within the EU markets. The European markets are also geographically closer to South Africa, making it easier to export perishable products at controlled temperatures. The short shipping times from South Africa to Europe have proven to be a strong comparative advantage for South Africa when compared to other southern hemisphere countries (Adriaen et al., 2004: 197). 


\subsection{History of South African export industry}

As is clear from the graph in Figure 1 below, growth in the export of South African table grapes was slow up to the late 1970s. The faster growth was triggered by the UK joining the European Economic Community (now known as the European Union or EU) and new markets becoming available to South Africa as a result. Exports increased steadily through to the early 1990s. The significant growth in production and export from the 1990s up to 2009 was driven by a number of factors, including (i) the growth of production of seedless varieties in the northern regions of South Africa, (ii) the deregulation of the industry in 1997 and (iii) arguably most importantly, access to more markets for the new South Africa with the expansion of democracy.

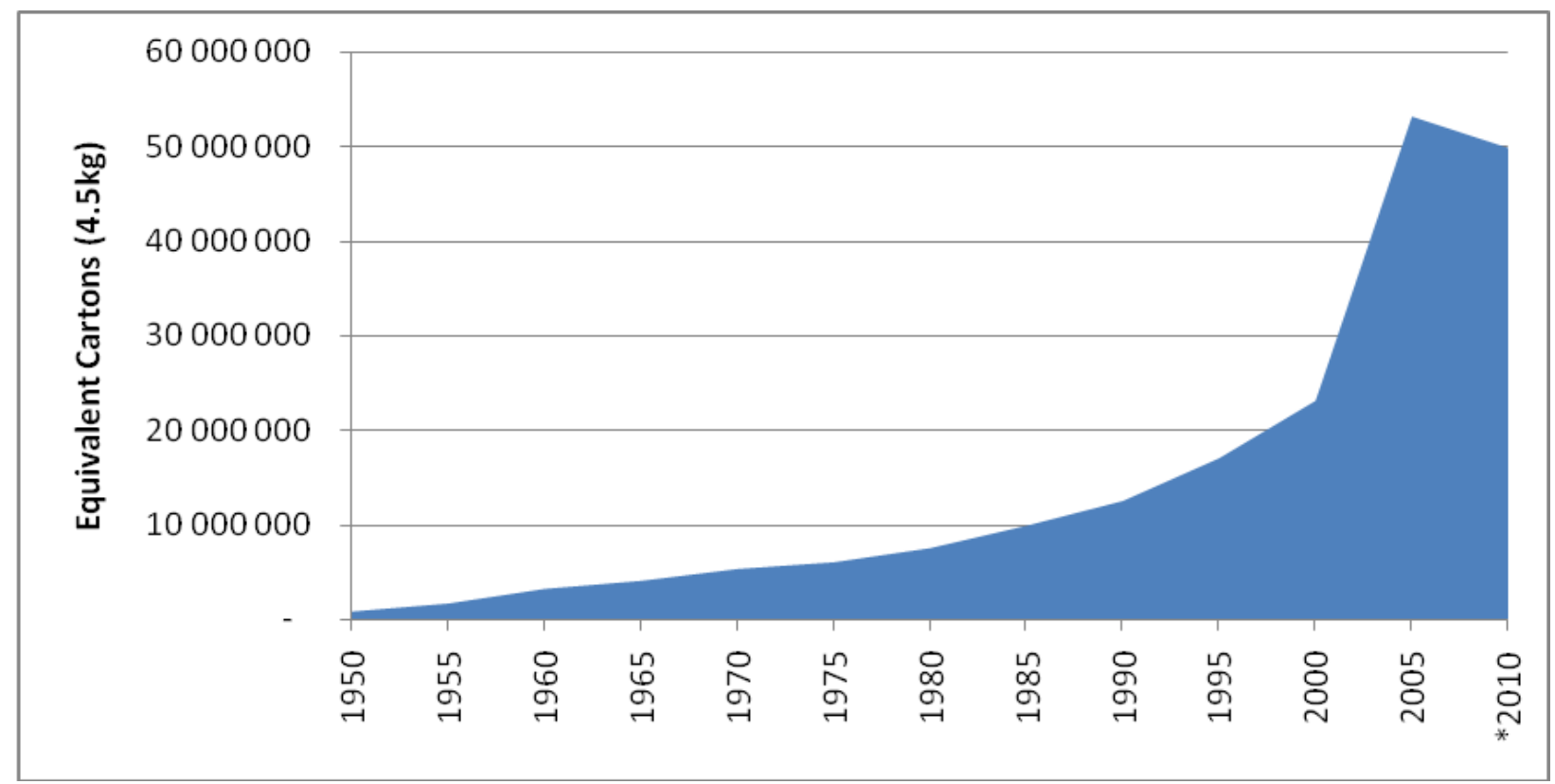

Figure 1: South African table grape export trend: 1950-2010

*Note: $1950-2009$ is actual data and $* 2010$ is estimated data

Source: (PPECB \& SATI: 2009)

Since around 2005 there has been a consolidation of production as a result of marginal profitability, largely due to the growth of production in South Africa and other southern hemisphere countries (i.e. Chile, Peru, Argentina, Namibia and Brazil), without the necessary market development and diversification. With consolidation has come much more of a marketdriven orientation and subsequent stability in the industry. The opening of new markets and the growth of consumption in the Far East and the Middle East may well trigger new growth in South African table grape production and export, as was observed in the 1980s. 


\subsection{The rise of other suppliers to Europe}

Ever improving supply chain technologies, the emergence of new viticulture techniques, postharvest technology innovation, more effective production inputs and new cultivars have all stimulated the production of table grapes in South Africa and other southern hemisphere countries over the last decade. As a result of the growth in production, the European markets have started to accommodate exports from other southern hemisphere countries such as Brazil, Namibia, Peru, Argentina and Chile. The harvesting time in these countries overlaps with the South African harvesting time; consequently, they compete directly with South African produce in northern hemisphere markets.

The Bureau for Food and Agricultural Policy (BFAP) ${ }^{1}$ has studied the impact of increasing volumes of exports from other southern hemisphere countries to European markets. In the report they released in February 2008, The Outlook for the South African Table Grape Industry, they showed that export volumes from Chile and South Africa, the largest and second-largest exporters of table grapes in the southern hemisphere, increased respectively by $4 \%$ and $6 \%$ per annum between 2000 and 2006 (BFAP, 2008: 3). Exports by Peru, New Zealand, Namibia and Brazil increased on average by $35 \%, 33 \%, 30 \%$ and $24 \%$ respectively from a low base over the same period (BFAP, 2008: 3). The BFAP results show that there will be an additional 68 million cartons in the export markets by 2012 (BFAP, 2008: 4). Southern hemisphere export volume has increased from 630000 tons in 1996 to over 1.2 million tons in 2008. The volume projection for 2014 is 1.35 million tons (SHAFFE, 2008). It should be pointed out that not all export volumes from the southern hemisphere are exported to Europe, although Europe makes up a large proportion of the global market.. The increase in volume caused the average price received for South African table grape exports to decline by 8\% each year from year 2000 to 2006 (Frudata, 2008 and BFAP, 2008: 4). This suggests that the export price will continue to drop unless a strategy of greater market diversification is pursued.

\footnotetext{
${ }^{1}$ BFAP, the Bureau for Food and Agricultural Policy, is a non-profit research organisation based at the Universities of Pretoria and Stellenbosch and the Western Cape Department of Agriculture. The primary aim of the BFAP is to offer high-level strategic and market analysis to all role players in the food and agribusiness sector in South Africa.
} 


\subsection{The emerging need for market diversification}

Over the past five years, South African producers have been confronted with production costs rising faster than export table grape prices. The weaker export price is caused by high competition in the traditional markets. South African producers face not only tough price competition in Europe, but also markets are constantly changing, now characterised by strict phytosanitary requirements. The traditional markets have put in place various kinds of non-tariff barriers, such as strict safety and handling standards, anti-dumping policies, and recently, barriers based on concerns over global warming. These factors are perceived as push factors that should motivate South African exporters and producers to start exploring alternative markets for their products.

There are pull factors that are increasingly encouraging South Africans to allocate some of their export volume to other markets (i.e. the Far East, the Middle East and Africa) away from Europe. The booming economy in the Far East countries and the large consumer market characterised by consumers with relatively high disposable income and spending ability are the main factors that should encourage South Africans to devote their focus to these developing markets. The Middle East is displaying growing opportunities for South Africa; this market has a limited consumer market size but importers from the Middle East are willing to pay higher prices than some of the European markets (e.g. Eastern European markets). Africa has also shown noticeable potential over the last three years, but logistical constraints, underdeveloped infrastructure and political instability cast a shadow on the growth potential of African countries.

The consumption of table grapes has increased significantly in many Asian countries over the last ten years. In the 1990s, China was the fifth largest consumer of table grapes in world rankings, and in 2006, China moved up to become the largest consumer of table grapes, consuming 3.8 million tons per annum (USDA, 2006: 4). The consumption of table grapes has declined slightly in Europe. The EU-25 was the largest consumer of table grapes in the early 2000s and is now ranked the second-largest consumer of table grapes, with 2.2 million tons consumed per annum (USDA, 2006: 5). The Asian markets are less protected by strict phytosanitary standards than European markets (TTM, 2005: 12). The other crucial advantage of Far East and Middle East markets is that they operate on a guaranteed price agreement (Fixed Price), while the European market is a consignment price market (Minimum Guaranteed Price). 
This means that before an exporter ships table grapes to the Far East or Middle East, a guaranteed price has already been set. The risk of receiving a lower price than was initially expected is minimal if the supply chain is managed properly.

Some global economic organisations such as OECD, the World Economic Forum, Global Insight and others, claim that the 'global economic map' is shifting and moving from the Western part of the planet towards the East. The main drivers of the economic map that have been identified include the open export base economy of China, from the early 2000s; the booming Indian economy, driven by its steel export sector and textile and automotive industries; and the improving infrastructure and economic growth in Middle East countries. The evolution of the formal retail sector in many Asian countries has also played a significant role in improving the social and economic environment in Asia. The free trade agreements and regional treaties such as the Brazil, Russia, India and China agreement (BRIC) and other bilateral agreements also seem to be good drivers of economic growth in Asia, allowing international participants in the Eastern economies. Table 1, shows some macroeconomic indicators that can be used to show the potential of China and India when measured in terms of economic growth and size of the consumer market.

Forecasts show that GDP growth will continue to grow above $7 \%$ in China and above $8 \%$ in India at least up to 2012. The table below also shows a trend of high consumer spending ability in these two countries. The consumer spending ability is projected to be $7.9 \%$ and $6.7 \%$ by 2012 for China and India respectively. Population growth is anticipated to continue for both countries (Global Insight, 2008). 
Table 1: Macroeconomic indicators for China, India and Europe

\begin{tabular}{|c|c|c|c|c|c|c|c|c|c|c|}
\hline & Unit & Country & 2005 & 2006 & 2007 & 2008 & 2009 & 2010 & 2011 & 2012 \\
\hline \multirow{3}{*}{ Population Growth } & Million & China & 1312 & 1325 & 1332 & 1343 & 1348 & 1351 & 1359 & 1368 \\
\hline & Million & India & 1134 & 1152 & 1176 & 1198 & 1211 & 1220 & 1249 & 1262 \\
\hline & Million & EU-15 & 384 & 386 & 387 & 387 & 388 & 388 & 389 & 389 \\
\hline \multirow{3}{*}{ Real GDP Growth } & $\%$ & China & 10.4 & 11.6 & 11.9 & 10.2 & 9.0 & 8.6 & 8.0 & 7.3 \\
\hline & $\%$ & India & 9.2 & 9.7 & 9.0 & 7.5 & 8.2 & 8.6 & 8.4 & 8.2 \\
\hline & $\%$ & EU-15 & 2.52 & 2.72 & 2.14 & 2.09 & 2.27 & 2.06 & 1.95 & 1.98 \\
\hline \multirow{2}{*}{$\begin{array}{ll}\text { Real Consumer } \\
\text { Spending }\end{array}$} & $\%$ & China & 8.0 & 7.6 & 7.2 & 7.4 & 7.5 & 7.7 & 7.9 & 7.9 \\
\hline & $\%$ & India & 8.7 & 7.1 & 8.3 & 5.7 & 5.9 & 6.7 & 8.2 & 6.7 \\
\hline \multirow{2}{*}{$\begin{array}{l}\text { Nominal GDP per } \\
\text { Capita }\end{array}$} & USD & China & 1710 & 2022 & 2483 & 3458 & 4069 & 4886 & 5666 & 6397 \\
\hline & USD & India & 716 & 794 & 975 & 1084 & 1202 & 1374 & 1545 & 1711 \\
\hline
\end{tabular}

Source: Global Insight, 2008

\subsection{Study objectives and expected outcomes}

The new table grape industry strategy reveals that SATI wants to expand its exports to Eastern markets. The new strategy aims to diversify the industry's current market risk profile in order to improve and protect its position in the global table grape markets (SATI, 2008: 7). The aim of this study is to investigate the viability of specific export market diversification scenarios. The general objective is to develop a deterministic farm-level model of a typical table grape farm in the Western Cape and Northern regions of the country. The farm-level model is developed based on accounting principles and operates as a tool for simulating and analysing the impact of changes in markets on the financial viability of the farms under different scenarios.

There are three export market diversification scenarios that were developed in this study. (i) Scenario 1 depicts the current market diversification, namely $85 \%$ of South African exports marketed in Europe and 15\% marketed in Asian and African markets. (ii) Scenario 2A portrays a situation where $60 \%$ of South African exports are marketed in Europe and $40 \%$ are marketed in 
Asia and Africa. The number of years taken to achieve Scenario 2A targets is 14 years. (iii) Scenario 2B shows an environment where $60 \%$ of South African exports are marketed in Europe and $40 \%$ are marketed in Asia and Africa. The number of years taken to achieve Scenario 2B targets is nine years. The justification for developing these scenarios is provided in Chapter Four.

The study adopts a scenario development process that has been used by many companies in their long-term planning sessions. Firstly, scenarios are able to represent the views and expectations of several stakeholders. Secondly, better than any other future-oriented tool, scenarios offer the possibility of integrating various kinds of data in a consistent manner. Besides quantitative data, scenarios can handle qualitative input (Bood and Postma, 2008: 7). It is these qualities that have resulted in the adoption of scenario development in this study. Knowledge gained from the study is expected to

* ensure optimum supply of developing markets, increase returns and reduce industry profile risk;

* further the understanding of emerging market requirements and characteristics (e.g. technical and environmental impediments);

* further the understanding of internal market forces (retail spread, distribution channels, consumer preferences and taste);

* determine the profitability of emerging markets as opposed to traditional markets.

\subsection{Thesis structure}

The thesis is structured in the following manner. The second chapter includes a comprehensive theory of scenario development derived from strategic management literature. This chapter contains various sections where the origins, uses and definitions of scenarios are discussed. The chapter proceeds by laying out the principles and functionality of scenarios. The series of scenario development steps are also discussed in this chapter.

The third chapter presents the study methodology. The chapter further provides the focal issue of scenarios and discuss the trends driving the scenarios. This chapter also describes the structure and process of scenario development. The financial models that were used to determine the profitability of the industry's production regions under different scenarios are also explained in chapter 3. The fourth chapter provides an overview of the South African table grape industry. This chapter gives background information on the table grape industry and explains the 
developments that have taken place over the last 120 years. The characteristics of the five South African table grape production areas are also discussed. The chapter further explains how European markets have shaped South African production patterns.

The fifth chapter gives descriptive market information. The characteristics of European, Chinese and Indian markets are discussed. The main objective is to evaluate the sustainability of these markets. This chapter intends to describe the story (i.e. qualitative information) part of the scenario development process and how relevant trends or events could unfold in the future under different market situations. The chapter concludes by providing the differences between these markets and discussing the implications of these differences on South African marketing and production of table grapes.

The sixth chapter provides a financial analysis that complements the theoretical part of the study by presenting numerical estimates of future indicators and helping to maintain the consistency of the storyline. The chapter identifies and quantifies the costs of driving forces and expresses their influence in numerical terms (using a deterministic farm-level model). Three scenarios are developed, depicting the different worlds of the table grape industry, namely Scenario 1, which is driven by current trends and presents the continuation of the current market situation, Scenario 2A, which is driven by globalisation, increasing southern hemisphere export volumes, economic growth and trade policy trends, and Scenario $\mathbf{2 B}$, which is driven by rising export volumes, improved quality standards and better industry information (intelligence). The study ends with conclusions, a summary and recommendations. 


\section{CHAPTER 2}

\section{LITERATURE REVIEW}

\subsection{Introduction}

In strategic management theory, a range of future planning tools have emerged over many years to assist managers to prepare for unexpected outcomes. Scenario development is one of the future planning tools that have proven to be effective in many companies. This chapter presents an overview of the literature on scenarios as a planning tool. It provides the origin and functions of scenarios and then presents cases where scenarios have been applied with success. The literature review shows different approaches to developing scenarios, which demonstrates that there is, as yet, no consensus about the best approach to use. Each approach has its own strengths and weaknesses. This study uses the intuitive logic approach to develop export market diversification scenarios for the table grape industry. This scenario development approach consists of two elements, namely the storyline and numerical models. The storyline describes the story, how relevant events unfold in the future, while the numerical model calculations complement the storyline by presenting numerical estimates of future indicators.

\subsection{Three schools of strategic management thinking}

In the strategic management literature, three schools of thought have arisen to interpret the way managers think about their organisations' strategies. These can be characterised as rationalist, evolutionary and processual schools of thought.

\subsubsection{The rationalistic paradigm}

In the 1950s and 1960s, strategic planning for the future was mostly based on the 'predict and control' principle, thus a rationalistic paradigm (Mintzberg and Water, 1990: 260). The rationalistic school codifies thought and action separately. The tactical underlying assumption is that there is one best solution or strategy, and the job of the strategist is to get as close to this as possible within the limited resources available. The rationalistic paradigm works well when the future mission is well defined. It starts with the definition of the purpose of the organisation (mission) and then derives a set of strategic objectives based on this mission. 
There have been major failures of rationalistic strategic management, and many of these failures are described in the book The Rise and Fall of Strategic Planning (Mintzberg, 1994). The most prominent cause of failure is that rationalistic planning can only work if things are clear and predictable. The other cause of failure is when the strategist selects a best strategy on the basis of maximum utility, resulting in no room for further arguments.

\subsubsection{The evolutionary paradigm}

The evolutionary school emphasises the complex nature of organisational behaviour, beyond the realms of rational thinking. In this paradigm, strategy is a perspective on emergent behaviour; a winning strategy can only be articulated in retrospect. In this context, evolution refers to the phenomenon of emergent properties of systems that have a discriminating and transmissible memory of successful strategies (Van der Heijden, 1996: 33). Discrimination may be selfapplied or imposed from the outside, but it ensures that the strategies which survive are those best fitted to do so. In this school of thought, strategy is a process of random experimentation and filtering out of unsuccessful strategies (Mintzberg \& Waters, 1990: 261). This traditional approach has gradually become less and less capable of modelling strategic thinking due to (Van der Heijden, 1996: 33):

- its minimal predictive power;

- logical problems with the notion of sustainable prescription for business success in a competitive world;

- growing insight into complexities that make one realise the importance of bettering the fundamental limitations to prescience

\subsubsection{The processual paradigm}

The processual school sees the organisation as a complex adaptive system. It is open to the outside world and adjusts its activities according to what it discovers there. Rationalist and evolutionist paradigms worry less about how the organisational process works "why bother if there is only one right answer or if there is no answer at all", but the processualist, on the other hand, is keenly interested in internal processes (Van der Heijden, 1996: 36). 
The processual approach to strategy is concerned with improving the fitness of organisations by creating processes that can utilise the resources available, scenario development being such a process. Scenario development deliberately confronts managers with environmental uncertainties by presenting them several fundamentally different outlooks on the future (Schoemaker \& Van der Heijden, 1992: 44). Generally, scenarios focus attention on causal process and crucial decision points. In doing so, scenarios highlight fundamental uncertainties surrounding the (strategic) decisions managers have to make. In this sense, scenarios may be seen as complementary to traditional forecasting and simulation techniques in order to provide a composite picture of future developments for use as a background for policy making and or strategic planning.

Strategic management has increasingly supported the use of scenarios rather than forecasts for long-term planning and strategic analysis (Zanoli et al., 2000: 3). Scenario analysis differs from other forecasting techniques in two important ways. Firstly, it usually provides a more qualitative and contextual description of how the present will evolve into the future, rather than one that seeks numerical precision. Secondly, scenario analysis usually tries to identify a set of possible futures, each of which is plausible but not assured and not necessarily probable (Schnaars, 1897: 107 and Zanoli et al., 2000: 3).

\subsection{Definitions of scenario}

The word scenario has multiple uses and one can expect the term to have various definitions. There are thus varying definitions of scenario, but on one point, there is consensus: "It is not a prediction." (Wack, 1985: 143 and Van der Heijden et al., 2002: 53). The characteristics inherent in the various definitions are that they are hypothetical, causally coherent, internally consistent and descriptive. A definition which covers many of the characteristics mentioned above is:

Scenarios are consistent and coherent descriptions of alternative hypothetical futures that reflect different perspectives on past, present and future developments, which can serve as a basis for actions (Van Notten, 2005: 2).

Other definitions related to the one above include: (i) Scenarios are a descriptive narrative of a set of relevant factors that are described from a probabilistic point of view (Huss, 1988: 379).

(ii) Scenarios are processes that depict some feasible future state of an organisation's 
environment and mostly include the dynamic sequence of interacting events, conditions and changes that are necessary to reach that state (Bood and Postma, 2008: 2).

\subsection{Origin of scenarios}

The term scenario has been borrowed from the theatre; it is an Italian term derived from the Latin word scaenarium (a place for erecting stages), and traditionally used to refer to the plot outlines used by actors of the commedia dell'arte (Van Notten, 2005: 1 and IDG, 2002: 15). Scenario was taken over by strategic planners after World War II to describe a method for war game analysis, and eventually it entered the civilian vocabulary through the work of Herman Kahn and others (IDG, 2002: 17).

\subsection{Evolution of scenarios}

The evolution of scenario development helps to explain key developments in the scenario development process. Scenarios first emerged during World War II as a method for military planning, when the US Air Force tried to imagine what its opponents might do, and prepare alternative strategies (Kahn and Wiener, 1968 and IDG, 2002: 17). In the 1960s Herman Kahn, who had been part of the Air Force effort, refined scenarios as a tool for business forecasting and became America's top futurist, predicting the inevitability of growth and prosperity. But scenarios reached a new dimension in the early 1970s with the work of Pierre Wack. In 1968, Wack was a planner in the London offices of Royal Dutch Shell, the international oil enterprise. Wack and his colleagues realised that member countries of the organisation of Petroleum Exporting Countries (OPEC) were likely to start demanding far higher prices for their oil. The only uncertainty was when.

Shell's directors listened carefully to Wack's presentations, but did not change their behaviour. As a result, Wack realised that, to be effective, scenarios had to change a manager's view of reality (IDG, 2002: 17 and Bradfield, 2005: 2). He then developed a new type of scenario that no longer consisted of simple tales of possible futures. Instead, he described the full ramifications of possible oil price shocks and tried to make people feel them. He vividly pointed to existing forces in the world and what sort of influences those forces would have, helping managers to 
imagine the decisions they might have to make as a result. As a result, Shell was the only major oil company prepared for the oil price shock and energy crisis that erupted in 1973 (IDG, 2002: 17).

Wack (1968) was no longer concerned with prognostication; his main concern was the mindset of decision makers. To operate in an uncertain word, they had to be able to reperceive, i.e. to question their assumptions about the way the world worked, so that they could see it more clearly. Thus the purpose of scenarios is to help decision makers change their view of reality to match it up more closely with reality as it is and reality as it is going to be. Scenarios deal with two worlds: the world of facts and the world of perceptions (IDG, 2002: 17). They explore for facts, but aim at perceptions inside the heads of decision makers. Their purpose is to gather and transform information of strategic significance into flesh perceptions.

\subsection{Nature and principles of scenario development}

Scenario development is a natural thinking tool for use in a strategic conversation (Van der Heijden, 1996: 54). It improves the fitness of organisations at two levels: (i) in the longer-term, development of a more robust organisational system, better able to withstand the unexpected shocks that will come its way, and (ii) in the shorter-term, increased adaptability by more skilful observation of the business environment.

Scenario development does not attempt to predict what is unpredictable, and for this reason, considers multiple, equally plausible futures. Scenario development succeeds when an organisation is willing to adapt itself so that it 'gains the high ground' (i.e. maximises its chances of achieving its purpose ${ }^{2}$ in whatever environment it finds itself, through a process of organisational learning. Scenario development is an effective method of organising a variety of seemingly unrelated economic, technological, competitive, political and social information and translating it into a framework for judgment.

\footnotetext{
${ }^{2}$ The basic organisational purpose is the double objective of survival and self-development (Van der Heijden, 1996: $55)$.
} 


\subsection{Types of scenarios}

Scenarios can be classified in various ways including: (i) qualitative vs quantitative (ii) exploratory vs anticipatory (iii) baseline vs policy scenario (Alcamo, 2001: 10-12).

(i) Qualitative vs quantitative

Most scenarios come in two basic forms: qualitative and quantitative. Qualitative scenarios describe possible futures in the form of words or visual symbols. They can take the shape of diagrams, phrases or outlines, but more often, they are made up of narrative text, the so-called storylines. The primary advantage of the qualitative scenario is to be able to represent the views of several different stakeholders and expectations at the same time. The drawback is that qualitative scenarios, per definition, do not satisfy a need for numerical information (Alcamo, 2001: 10).

The quantitative scenario provides needed numerical information in the form of tables and graphs. Its disadvantage is that the exactness of its numbers is sometimes taken as meaning that we know more about the future than we actually do. Another disadvantage is that quantitative scenarios are usually based on results of computer models, and these contain many implicit assumptions about the future. It has been argued that these models tend to represent only one point of view about how the future will unfold, and in this way produce scenarios that are unnecessarily narrow in view (Alcamo, 2001: 10).

(ii) Exploratory vs anticipatory

Another way to classify scenarios is to distinguish between exploratory and anticipatory scenarios. The exploratory scenarios (also known as descriptive scenarios) are those that begin in the present and explore trends into the future. This comes close to the original meaning of the word scenario in the sense that it is a sequence of emerging events. The exploratory scenarios are much more common in strategic management studies, perhaps because they require less speculation about the future than anticipatory scenarios. Anticipatory scenarios (also known as prescriptive or normative scenarios) start with a prescribed vision of the future and then work backwards in time to visualise how this future could emerge (Alcamo, 2001: 11). 
(iii) Baseline vs policy scenario

Another useful way to classify scenarios is to distinguish between baseline and policy scenarios. Baseline scenarios are known as reference, benchmark or non-intervention scenarios. They present the future state of society and the environment in which environmental policies either do not exist or do not have a discernable influence on society or the environment. The baseline scenarios can be used to evaluate the consequences of current policies in the future with no new policy intervention (Alcamo, 2001: 12).

Policy scenarios depict the future effects of trade, environmental and social protection policies. Policy scenarios are also known as mitigation or intervention scenarios. A major purpose of policy scenarios is to identify policies that attain specific environmental goals and examine the economic impact of specific environmental policies (Alcamo, 2001: 12).

\subsection{Functions of scenarios}

Scenarios have now claimed to fulfil a wide range of different functions (see Table 2, below). Some of these functions are concrete and clearly visible. The newer ones are more abstract and bring about intangible products.

Table 2: Summary of the main functions of scenarios

\section{Original functions:}

1. Evaluation and selection of strategies

2. Integration of various kinds of future-oriented data

3. Exploration of the future and identification of future possibilities

\section{More recently added functions:}

4. Making managers aware of environmental uncertainties

5. Stretching of managers' mental models

6. Triggering and accelerating processes of organisational learning (stimulating creativity)

Source: Bood \& Postma, 2008: 6-9 
The first function of scenarios is to provide a background for the evaluation and selection of strategies. Scenarios can provide a framework within which all the various factors and information can be more effectively and easily judged by the decision-maker (Bood and Postma, 2008: 6)

Secondly, better than any other future-oriented tool, scenarios offer the possibility to integrate various kinds of data in a consistent manner. Beside quantitative data, scenarios can handle qualitative input, incorporate results from other forecasting techniques and allow for soft and fuzzy variables. This function is especially useful as a considerable part of the knowledge used in formulating strategies is qualitative in nature (Bood and Postma, 2008: 7).

Thirdly, scenarios are means to explore the future and identify what might possibly happen and how an organisation could act on or react to future developments. In fact, Kahn and Wiener's (1968) early definition of scenarios emphasises this function by defining scenarios as: "hypothetical sequences of events constructed for the purpose of focusing attention on causal processes and decision points." Good scenarios enlarge managers' understanding as to what is significant versus what is ephemeral. This allows for anticipation of the unexpected and provides for an early warning system (Schoemaker, 1995: 27).

The fourth function of scenarios has increased in importance from the seventies onwards and is central to multiple scenario development nowadays, namely, making managers aware of environmental uncertainties. Scenario development brings uncertainty into the management process by confronting managers with fundamentally different future states. As uncertainty is a basic structural feature of the business environment nowadays, the better approach is to accept uncertainty, try to understand it and make it part of our reasoning (Bood and Postma, 2008: 7).

The fifth function is that scenarios are seen as ways to stretch managers' mental models by explicitly confronting them with their own biased viewpoints. Based on education and experience, amongst other things, managers have developed their own mental models on the basis of which they act. Mental models contain both personal explanations of situations and guidelines for action in these situations. Scenarios aim at challenging managers' existing mental models and entrenched corporate convictions (Millett, 1988: 63). By surfacing and testing mental model scenarios, one facilitates the building of consensus within a management team (Tenaglia and Noonan, 1992: 14). 
Finally, and closely related to the foregoing function, scenarios are increasingly considered as tools to trigger and accelerate processes of organisational learning. Learning on a strategic level is hindered by both the long time span that elapses between action and result, and cognitive inertia that people demonstrate when absorbing new information and adapting their mental models accordingly. Scenarios are representations of the real world that can serve as transitional objects with which managers can play, and in doing so, learn from considerably faster (Bood and Postma, 2008: 9).

\subsection{Scenario development process}

Up to this point, the study has discussed the origin, principles and functionality of scenarios. In this section, the discussion concentrates on the process of developing scenarios. Three methodological approaches to scenario development are described below (Zanoli et al., 2000: 12-14).

(i) Intuitive Logic

This approach is linked to strategic management methods and companies' participatory planning processes. The background of this approach is that organisational decisions refer to complex relationships involving economic, social, technological, political and environmental aspects (Postma and Liebl, 2005: 162). In the environmental assessments area, it is referred to as the story and simulation approach (SAS), which combines qualitative and quantitative information (Alcamo, 2001: 16). It consists of two main elements (storyline and numerical models). The storyline describes the story, how relevant events unfold in the future, while the model calculations complement the storyline by presenting numerical estimates of future indicators and helping to maintain the consistency of the storyline. Intuitive logic approaches have been used by Wack (1985) from Royal Dutch Shell, Van der Heijden (1996) and Von Reibnits (1988) in their scenario development processes.

(ii) Trend Impact Analysis

The second approach is an intermediate one between intuitive logic and cross-impact analysis and represents a trade-off between scenario analysis and traditional forecasting methods. Its simplest form is a quantitative statistical forecasting model enriched by qualitative assessments, 
which allows for the definition of possible events that might modify the estimated trends. This approach turns out to be effective for at least two reasons: It combines traditional and qualitative forecasting techniques and stimulates analysts, and it expects to take into account possible effects of unusual events. The limitation of this approach is the low degrees of formalisation of the definition and evaluation of the trend impacts (Wolfe and Flores 1990: 392).

(iii) Cross-Impact Analysis

This approach originated from the Delphi method, developed by Gordon and Hayward (1968). The basic concept of cross-impact analysis is that the approach tries to assess conditional probabilities in a highly interconnected system (events are considered as interdependent). It allows the generation of a large number of synthetic future stories that can be considered as basic schemes or frameworks for scenarios. The criticism of this approach stems from Schnaars (1987), who warns that cross-impact analysis should avoid highly mathematically formalised procedures as these might reduce the predictive accuracy and clarity of scenarios.

The wide range of different approaches to scenario development demonstrates that there is as yet no consensus about the best method to use. Each method has its own strengths and weaknesses. Concerning the application of scenario development to the South African table grape industry, the lack of detailed quantitative information about table grapes in the Far Eastern and Middle Eastern markets does not allow the adoption of trend-impact and cross-impact models, as they both require more detailed data. The following segment discusses the scenario development process using the intuitive logic approach as discussed by many authors in scenario-development literature. Various approaches or processes of constructing scenarios can be found in the literature (Godet, 1987; Huss, 1988; Porter, 1985; Schwartz, 1991, and Van der Heijden, 1996). Although scenarios are far from constructed according to some kind of standardised process, and various differences can be observed between the various approaches, they all have the same basic structure (Bood and Postma, 2008: 4 and IDG, 2002: 22). A typical scenario process consists of a series of phases which are, at least intentionally, completed sequentially (Bood and Postma, 2008: 4). These are described in Figure 2 


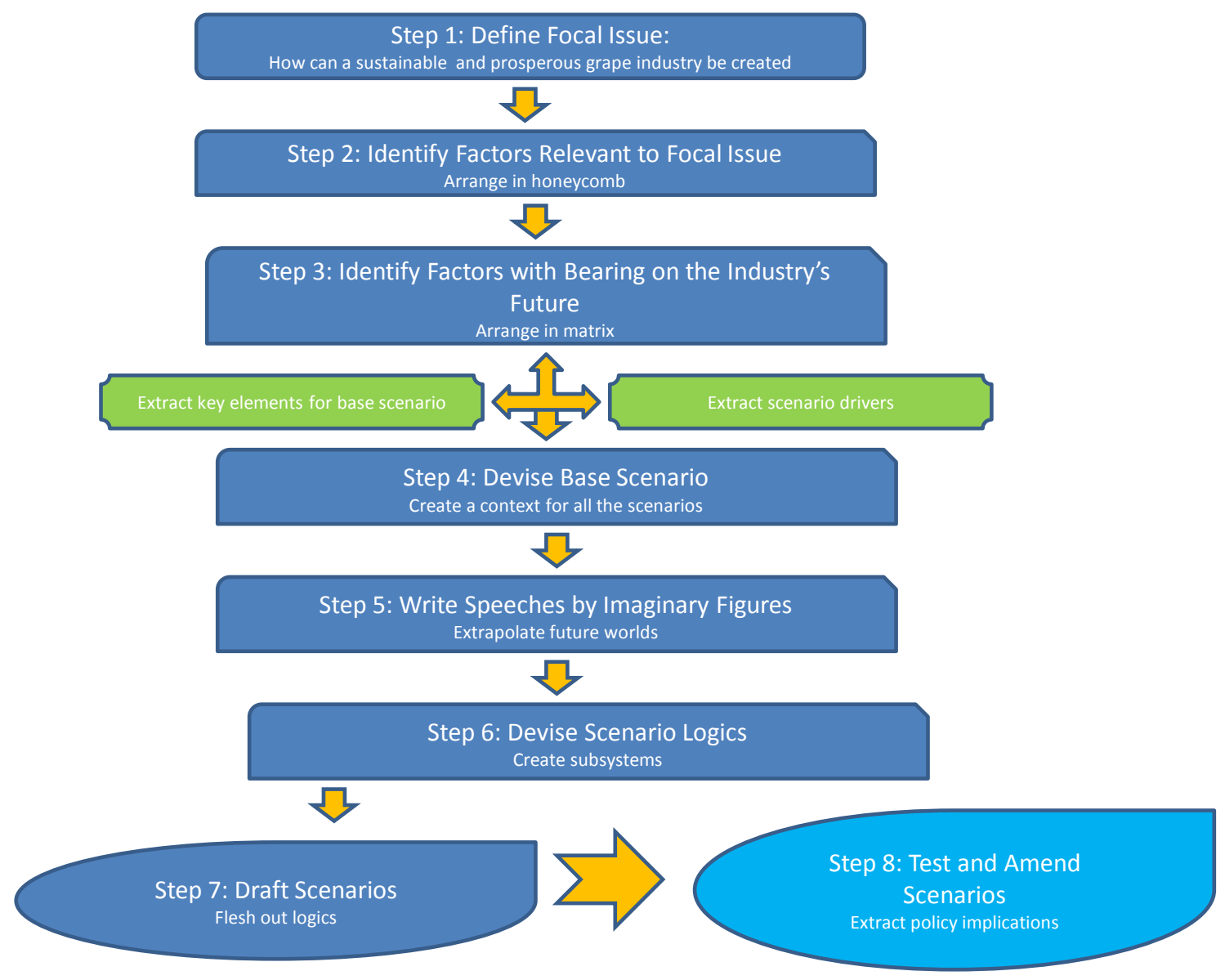

Figure 2: Eight steps of scenario development process

Source: Bood \& Postma, 2008: 4-6; Van der Heijden, 1996: 186-193 and IDG, 2002: 22-23

The first step is to define a focal issue or a key decision that needs to be taken. The second is to identify key factors or trends in the local environment that will impact on the issue or decision in step one. The third is to identify driving forces in the macro environment that influence the key factors identified earlier. These forces influence the outcome of events, the elements that move the plot of a scenario or determine a story outcome. They are devices for honing the initial judgement, for helping one decide which factors will be significant and which factors will not. After identifying and exploring the driving forces, it must be determined which are predetermined and which are uncertain.

The fourth step is to rank key factors and driving forces on the basis of two criteria: (i) the degree of importance to the focal issue or decision, and (ii) the degree of uncertainty surrounding those factors and trends. The aim of the cross-impact matrix is to identify the two or three factors or trends that are most important and most uncertain. 
The fifth step is to write the story and extrapolate future worlds. These are stories that describe how the driving forces might plausibly behave, based on how those forces have behaved in the past. The sixth step is to devise scenario logics. Each key factor and trend should be given some extra attention in each scenario and then the pieces should be woven together in the form of a narrative. The objective of this step is to determine what event might be necessary to make the end point of the scenario plausible. The seventh step is to draft scenarios. Once the scenarios have been developed in some detail, it is time to return to the focal issue or decision identified in step one. In this phase, the aim is to reveal the vulnerabilities of the scenarios and determine how a strategy could be adapted to make it more robust if the desired scenarios show signs of not happening.

The eighth and final step of scenario development is to select leading indicators and signposts. If those indicators are selected carefully and imaginatively, the company or organisation concerned will be more flexible and receptive to the future. There are two considerations that should be noticed if one is developing the scenarios: (i) Beware of ending up with three scenarios. People not familiar with scenarios or their use will be tempted to identify one of the three as a middle or most likely scenario, and will then treat it as a single-point forecast. (ii) Avoid assigning probabilities to different scenarios because of the temptation to consider seriously only the scenario with the highest probability (Bood and Postma, 2008: 6 and IDG, 2002: 23)

\subsection{Criteria for the evaluation of scenarios}

Scenarios cannot be evaluated on the basis of their predictive accuracy, as the probability of a single scenario happening completely is close to zero (Van der Heijden, 1996: 15). As a general criterion, 'credibility' can be used in order to evaluate scenarios, which can be considered to have four major strictly interlinked determinants (Zanoli et al., 2000: 6-7).

(i) Comprehensiveness

The scenario should be able to take into account all relevant events and trends. General and comprehensive scenarios make the analysis plausible. 


\section{(ii) Clarity}

This depends mainly on three factors. The first is the balance between simplicity and realism. The second is the unbiasedness of procedures translating subjective assessments into objective, generally acceptable statements. The third factor is the complexity of computing algorithms (if these are too complicated, decision makers and role players might dislike scenarios).

(iii) Consistency

This concerns the validity of the basic information set and how it has been used, specifically with regard to the cause-effect relationship among variables. Nevertheless, too much emphasis on consistency may favour the elimination of scenarios that look inconsistent only because they present innovative situations.

\section{(iv) Coherence}

A scenario is coherent if it does not violate the basic rules and assumptions of the theory upon which it is based. For instance, a model using probability assessment might have coherence problems if it is generated without respecting basic probability theory rules. Coherence is a fundamental requirement, because it provides the conceptual basis for the interpretation of results and favours using scenario techniques with a sound theoretical framework.

\subsection{Pitfalls of scenario development}

Many academics and practitioners acknowledge that scenarios are effective in dealing with uncertainties. However, managers are nowadays confronted with totally new and entirely unanticipated situations that are indicative of blind spots inherent in this method (Liebl, 2002: 175 and Bohensky et al., 2006: 1051). The scenario approach, as it is commonly practised, is not able to deal with complex developments and trends, which can be characterised as paradoxical, because they tend to be systematically excluded as logically impossible or inconsistent during the scenario development process. This is particularly true for conventional and trend-based scenarios based on simple causalities and mere extrapolation of the past and the present to the future. They cannot deal well with these kinds of complex trends, which used to be an exception but have now become a rule. Complexity is growing, causality relationships may be ambiguous and changes are speeding up with severe consequences (Postma \& Liebl, 2005: 162). The sociopolitical and cultural environment turn out to be particularly unpredictable, public issues emerge 
as total surprises and companies are faced with the simultaneity of trends and countertrends. In these situations, scenarios offer little help because uncertainties are surpassed by unknowables, indicated in the diagram in Figure 3, below, as the area where only 'hope' may be helpful (Postma \& Liebl, 2005: 166).

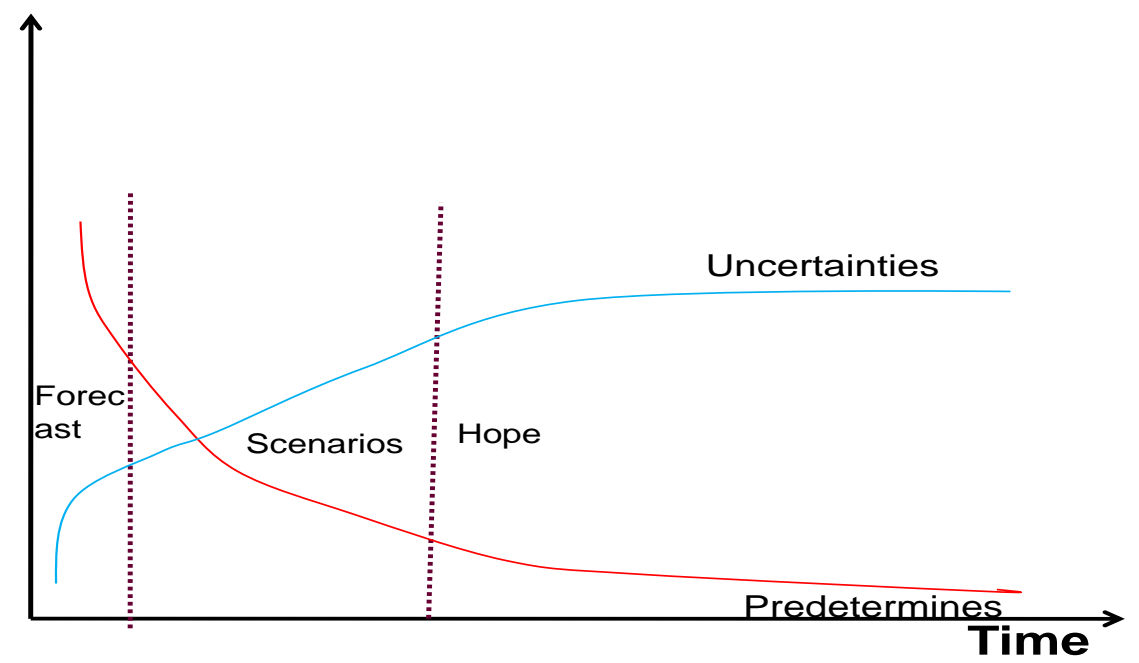

Figure 3: Forecasting, scenarios and hope

Source: Postma and Liebl, 2005: 166

The first issue, that of unknowables, is related to the idea that the scenario approach has to deal with what is known and what is not known in order to provide relevant information for early warning purposes (Postma and Liebl, 2005: 166). Scenarios aim at predeterminables and uncertainties. The existence of predeterminables is based on the assumption that the alternative future outcomes of events and developments and their probabilities are a priori known; in case of uncertainties, the outcomes are known, but not their probabilities. For unknowables, even the outcomes are not known. Moreover, these unknowables cannot, by definition, be forecasted, and therefore, form the ultimate challenge because they could become relevant for decision makers.

This growing problem was brought to management attention by Ansoff (1976), who distinguished between 'uncertainties' and 'ignorance' with respect to future developments, and emphasised the role of the latter with respect to strategic discontinuities (Postma and Liebl, 2005: 166). This has severe implications for the kind of information that has to be processed in 
strategy formulation, resulting in specific requirements for scenario building. The classification of Schoemaker (1995) can be helpful to illustrate what Postma and Liebl (2005) mean here. The relevant future knowledge can be discussed by distinguishing between three classes of knowledge:

1. Things we know we know

2. Things we know we do not know

3. Things we do not know we do not know

Knowledge of type 1 is evident. Scenario development is especially helpful at supporting knowledge development of type 2. The main challenge is to transform knowledge of type 3 into knowledge of type 2. Scenario development should be more receptive of and oriented towards exploring and discussing these inconceivable elements. Otherwise, the requirements for a true early warning function would not be met (Postma and Liebl, 2005: 167).

The second issue indicates that scenarios do not prevent management from being surprised. Companies are regularly confronted with entirely unanticipated situations. Thus, although scenario development does not mean forecasting and nobody would seriously claim that scenarios should predict the future in exact detail, it is striking how often situations occur that were simply not included, or were excluded as logically impossible or inconsistent during the process of scenario development (Postma and Liebl, 2005: 167). Scenarios cannot deal with inconsistency, especially when the future (or even current) situation does not lie within the corridor of the various extreme but consistent forecasts, but rather lies beyond it and reveals different dimensions in surprising combinations. If scenarios cannot deal with the element of inconsistency, serious problems in strategic decision making could result (Liebl, 2002: 183).

\subsection{Scenario development in agricultural sector}

A literature review on scenarios suggest that scenario planning in the agricultural sector has been underutilized as compared to oil, finance and air-force sectors. The application of scenario planning in the agricultural sector has increase significantly over the last two decades, boosted by the changes in climate, consumer preferences and market conditions. Scenarios has been also widely used in environmental studies (i.e. land use) to enhance environmental quality, thus 
improving water quality, creating greater biodiversity and rural development. The following sections present examples of case studies conducted using scenario development.

1. Scenario development has been used as tool to examine the future of the Corn Belt in the Mississippi River (US) agricultural landscape (Nassauer et al., 2007: 41). They argue that current agricultural practices in the Corn Belt do not enhance environmental quality. They describe the need for alternative agricultural land uses and practices throughout the Mississippi River Basin (MRB). Three scenarios were created, which depict agricultural practices in the MRB by 2025 . The scenarios are intended to anticipate and envision the possibility of a future that could be surprisingly different from the present. One of the reasons to consider such surprising futures is that the Corn Belt agricultural landscape has changed in many unanticipated and not always desirable ways, because of the cumulative effects of environmental practices such as hypoxia, degraded local water quality and dramatic losses of biodiversity.

The three scenarios are: (i) Increasing agricultural commodity production: The main goal of this scenario is to increase commodity production over the short term, where primary crops are assumed to be corn and soya beans. The scenario encourages cultivation of all highly productive land and the use of conventional technologies and inputs. Consequently, by 2025, all highly productive farm land will have been converted to row crops. (ii) Improving water quality and reducing downstream flooding: This scenario encourages comprehensive adoption of innovative practices to improve water quality and hydrologic regimes. In this scenario, more farmers will occupy the Corn Belt in 2025 compared with the other scenarios, because farmers are needed to manage livestock in rotational grazing. This scenario creates an appealing landscape that attracts tourists, hunters, telecommuters, retirees and second-home owners. The local population and local services, schools and churches that existed in the early 2000s will have increased and broadened by 2025. (iii) Enhancing biodiversity within agricultural landscapes: The goal of this scenario is to enhance biodiversity in the context of agricultural production. As a means of achieving that goal, perennial grasses are grown for market enterprises. Native perennials are integral to a new system of Corn Belt bio-reserves. 
2. OECD developed a variety of scenarios depicting different futures around food scarcity. In their 2001 publication, Environmental Outlook by 2020, they presented different scenarios. In the scenario labelled Reference Scenario, which is driven by factors such as demographics, socio-cultural influences, consumer incomes, technological developments, governmental policies, product prices, trade liberalisation and environmental policies, interesting aspects are discussed. This scenario reveals that food available worldwide for direct human consumption (after accounting for non-food uses and losses) has risen dramatically over the last 20 years and is expected to increase by $10 \%$ by 2020 , reaching, on average, $3000 \mathrm{kcal} /$ person/day (OECD, 2001: 86). In monetary terms, worldwide agricultural production is expected to grow by 94\% between 1995 and 2020, while in OECD regions, it may increase by almost $40 \%$ in the same period (OECD, 2001: 87).

3. In recent years, bioenergy has drawn attention as a sustainable energy source that may help cope with rising energy prices, but also provide income to poor farmers and rural communities around the globe. Scenario development has been adopted to examine the potentially adverse impacts from a rapid bioenergy expansion to include upward pressure on international food prices, making staple crops less affordable for poor consumers (Msangi et al., 2007: 1). Given the numerous and high levels of uncertainty regarding future biofuel supply, demand and technologies, three alternative scenarios were examined: (i) conventional scenario, which focuses on rapid global growth in biofuel production under conventional conversion technologies; (ii) second-generation scenario, which incorporates a softening of demand on food crops due to secondgeneration, lingo cellulosic technologies coming online; and (iii) second generation plus scenario, which adds crop productivity improvements to the second-generation scenario. Dramatic increases in world prices for feedstock crops by 2020 are expected. The highest price impacts are seen for oil and sugar crops, followed by staple crops. Under the conventional scenario, with aggressive demand for biofuel feedstock from traditional food and sugar crops, the number of malnourished children increases by 11 million, with the largest absolute increase in sub-Saharan Africa, followed by South Asia (Msangi et al., 2007: 8). 
4. Scenarios as long-range planning tools have been used by organisations such as the World Business Council for Sustainable Development (WBCSD) to promote efficient use of water. In their 2006 publication, Business in the world of water: Scenarios to 2025, they evaluate alternative ways of managing water and examine the impact of water scarcity on business development (see www.wbcsd.org).

Other global organisations that have practised scenario planning include the World Economic Forum (WEF), Global Insight and the United Nations (UN). In 2008, WEF created a number of scenarios to identify critical issues facing the world. Their scenarios incorporated the effect of rising global population, urbanisation in emerging countries, improving technology, and changing climate in the global economy (WEF, 2008: 3). Some of the scenarios created by WEF in 2008 include the Hyperlinked World Scenario: The hyperlinked world of 2025 is a world of possibilities. Advancements in physical, technological and cyber infrastructure cause communication costs to drop sharply while people, businesses and governments experience a great leap forward in their degree of interconnectedness. The global order in 2025 is governed by networks, communities and interest groups. The Sustainable World Scenario: The sustainable world of 2025 is a world dealing with a soaring population, rapid urbanisation and ongoing climate change problems. Water and food scarcities lead to new pockets of instability and force a major global response to emerge into a new sustainable order of politics and business. The emergence of a planet-wide consciousness of the environment forces businesses and governments to adopt new policies of corporate global citizenship and sustainability. The Multipolar World: In the multipolar world of 2025, the epicentre of the global economy is in the East. New centres of power, fuelled by strong growth, emerge, while global energy demand places oil exporters under pressure. The trade and investment environment focuses on the new Asian powers that play an increasingly assertive role in international politics. The Middle East is engulfed in a geopolitical competition for influence, power and ideas. 


\subsection{Scenario development in South African agriculture}

Scenario development has been used in South African agriculture. The following sections represent the cases where scenario development has been practised.

1. The Department of Agriculture and the Department of Science and Technology have formulated an agricultural and agroprocessing sector working group. The working group has developed numerous scenarios with a mandate to ensure that future opportunities presented by research and technology will address the social and economic challenges South Africa faces with regard to the performance of the agricultural and agroprocessing sector. These scenarios help the human mind to at least recognise the possibilities of change in the socioeconomic environment of the country.

A set of four macro scenarios depicting four possible roads South Africa could take to 2020 are presented below (Van Zyl, 2007: 30): (i) The frozen revolution highlights the effect of non-implementation of government policy on socioeconomic upliftment, leaving the masses dissatisfied and key players fragmented and individually focused; (ii) The innovation hub describes how South Africa's comparatively developed infrastructure creates opportunities for strategic regional development; (iii) The global home is about government embracing global liberalisation and facilitating private-sector empowerment to respond to global market forces, in line with global trends and opportunities; and (iv) Our way is the way depicts South Africa's perceived ability to challenge the conventional route to globalisation by rallying developing countries' support for the development of a significant South-South economic bloc.

2. The Institute for Global Dialogue (IDG) and the South African office of the Friendrich Ebert Stiftung (FES) of Bonn developed five scenarios in response to the challenges facing the country and the region (i.e. its multilateral institutions, notably the Southern African Development Community - SADC). The scenarios aim to address various international and domestic factors such as globalisation, trade negotiations, conflict and instability in the region, poverty, HIV/AIDS and growing climatic disturbances (IDG, 2002: 13). The five scenarios include: (i) Baseline scenario, which presents key trends in the region, in the economic, social and environmental spheres, by 2020 . The baseline scenario indicates that by 2020, with the effect of HIV/AIDS, population growth is outstripping economic growth in numerous countries within the SADC region. As a 
result, there are high and increasing levels of poverty in the region. This, combined with unequal development, is leading to large and growing disparities of wealth. There are some positive factors (i.e. privatisation is boosting infrastructure and financial volatility will probably diminish), but these are far outweighed by the former trends (IDG, 2002: 29).

The other scenarios include (ii) danger scenario, which is driven by conflict and a rapidly deteriorating security situation; (iii) regional renaissance scenario, which is driven by visionary leaders; (iv) the slow slide scenario driven by socio-political decay; and (v) market madness, which is driven by globalisation. These scenarios show that in the year 2020, most countries and their economies are controlled by wealthy elites. While most countries in the region are democracies, levels of popular participation in formal democratic institutions are low, and as a result, the poor are dominated by the elites. Even while economic growth rates are high, there is little or no employment growth, big businesses make big profit, but the majority of people are poor and survive in the informal economy. Economic growth is also occurring at the cost of the environment.

3. In 1997, a study was conducted to examine the environmental trends in the Southern African region and develop environmental scenarios to the year 2015, and relate these to socioeconomic and geopolitical factors. One of the scenarios developed is the doomsday scenario - the road to unsustainability. In this scenario, it is assumed that most, if not all negative trends in the region will not only continue, but will worsen and accelerate. Some trends (e.g. population growth) have in-built momentum. In these circumstances, it was postulated that serious environmental consequences would ensue and would ultimately lead to a nightmare scenario with widespread conflict, extensive environmental degradation and human misery. This road to unsustainability would be driven by a variety of factors: economic stagnation and decline, worsening poverty, rapid population growth, HIV/AIDS and rapid increases in the rate of urbanisation as a result of refugees.

4. In recent years, scenario development has gained more popularity in the South African agricultural sector. The establishment of the 
(BFAP) in 2004 has lead to active usage of scenarios in the agricultural sector. BFAP is an independent research unit involving the University of Pretoria, the University of Stellenbosch, and the Department of Agriculture in the Western Cape, as well as the Food and Agricultural Policy Research Institute (FAPRI) and associate organisations. Their main objectives are (see www.bfap.co.za)

- to facilitate informed decision-making by South African policy makers, agribusinesses, trade negotiators and farmers through improved analytical capabilities;

- to enhance the quality and quantity of applied disciplinary and cross-institutional research related to applied trade and policy modelling and commodity market analysis;

- to analyse future policy and market scenarios and measure the impact of these on farm and firm profitability.

BFAP sees the purpose of using the scenarios as firstly to understand the key drivers and uncertainties shaping agricultural markets and policies. By understanding these shaping forces, BFAP is in a better position to inform decision makers in both the private and public sectors with regard to strategic business decisions and policies. Secondly, the scenario results are used to improve and enhance the system of models that is used by BFAP to do market and policy analysis. This is done by adjusting the model structures on a proactive basis in order to 'keep up with reality', as learnt through the scenario development process (BFAP website, 2009). The BFAP develops different scenarios across the South African agricultural sector and publishes them in its annual publication, BFAP Baseline Report.

\subsection{Conclusions}

This chapter presented a literature review on scenario development. It was shown that the primary advantage of scenarios is their ability to represent the views of several stakeholders and their expectations at the same time. Secondly, better than any other future-orientated tool, scenarios offer the possibility of integrating various kinds of data in a consistent manner. Besides quantitative data, scenarios can handle qualitative input. It is these qualities or advantages that 
have resulted in the adoption of scenario development in this study. This study uses the intuitive logic approach to develop export market diversification scenarios for the table grape industry. 


\section{CHAPTER 3}

\section{BACKGROUND INFORMATION ON FARM MODELLING AND SIMULATION}

\subsection{Introduction}

Table grape farms in South Africa operate in a fast moving and constantly changing decisionmaking environment. The environments in which farms operate have become increasingly complex due to significant changes that have taken place over the past decade. Due to the increased complexity, the systems theory or approach was adopted in the agricultural economics field to improve research and practical problem-solving in order to improve the decision-making process (Strauss, 2005: 20). This chapter aims to provide background information on farm modelling and simulations that are used to enhance decision making in agriculture.

\subsection{Definition of modelling and simulation}

Various definitions and methods of modelling and simulation exist in the literature. Modelling and simulation are defined as follows: Modelling is building a representation of a system, while simulation is experimentation with the represented system by means of a model (Strauss, 2005: 12 and Johnson et al., 1977: 162). Simulation, therefore, implies an experiment in which the objective is to represent or reproduce the relationship between objects or persons in a real-world system and predict the likely behaviour or responses of these objects or persons in the specific system (Csaki, 1976: 25).

\subsection{The process of simulation}

In natural science, simulation is most often done by means of a physical model, but in the case of economics, it is virtually impossible to build a physical model for experimental purposes. The reason is that there are too many variables, mainly social, that influence the economic system significantly and which cannot be captured in a physical economic model (Strauss, 2005: 12). In agriculture, many experiments are conducted by means of a physical model in the case of biology or agronomy, but in agricultural economics, most are conducted by means of computer models. The reason for the usage of computer models is the same as in the case of economics (Strauss, 2005: 13). 
Since the main objective of simulation is to describe reality as realistically as possible, many different approaches to simulating agricultural problems exist. However, the logic of simulating agricultural systems remains similar, as explained in the diagram (Figure 4) below.

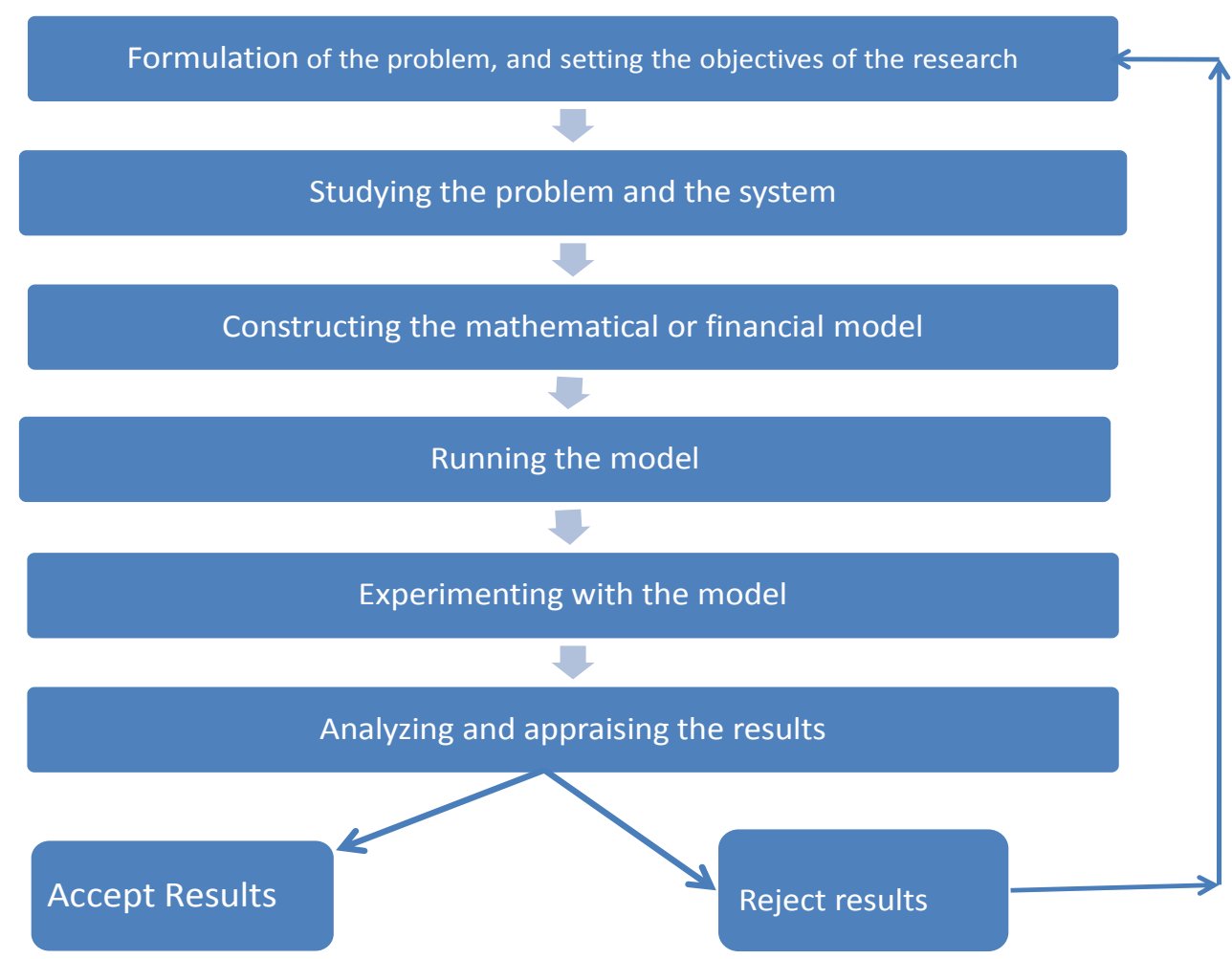

Figure 4: The order of implementation of simulating economic problems

Source: Csaki, 1976: 36 and Strauss, 2005: 13

\subsection{Farm simulation models: type and purpose of modelling}

The type of farm simulation model to be used depends on the type of system being modelled and the purpose of modelling or simulating the system (Johnson et al., 1977: 166). The literature distinguishes and discusses two basic types of models, namely deterministic and stochastic models (Strauss, 2005: 14-15; Richardson, 2003 and Johnson et al., 1977: 171).

The deterministic models are models in which the probabilities of the different values of the models' variables are one, and in which the system relationships are constant. The output of a deterministic model is therefore definite. The deterministic models do not incorporate risk 
because of the fixed nature of the variables' values and interrelationships in the system. Consequently, deterministic models are used to simulate specific outcomes, given a set of specified inputs.

The stochastic models contain random variables and relationships, and therefore, the output of the model consists of random elements or probability distributions. The stochastic simulation models incorporate risk by assigning a probability distribution to specific exogenous and endogenous variables. Key output variables are simulated and represented by probability and cumulative distributions. The probability and cumulative distribution functions are used to quantify and compare the risks associated with different scenarios and decisions.

\subsection{Farm simulation models: approaches of simulation}

There are two basic approaches to simulating farm models, namely a normative approach and a positive approach. The normative approach implies optimising a system or attempting to quantify 'what must happen' to the system, while the positive approach implies describing a system or attempting to quantify 'what is likely' to happen to the system.

\subsubsection{The normative approach}

The literature indicates that a number of methods have been developed and used when following a normative approach to farm simulation. Included in these methods are (i) mathematical programming, (ii) production functions, (iii) input-output analysis and (iv) network analysis (Csaki, 1976: 22 and Strauss, 2005: 16). The mathematical programming models, in general, consist of mathematical relationships and constraints that are solved in order to calculate an optimal solution to a system given a set of constraints. In other words, the answers that are obtained are normative answers or 'what must be' answers (Richardson, 2003 and Strauss, 2005: 16). In the 1970s, mathematical programming developed in order to apply it to problems to reflect reality to a greater extent. Types of models that were developed include (i) the linear dynamic model, (ii) the integer model and (iii) the non-linear programming model.

The purpose of the input-output model is to present the system modelled as closely as possible, without explaining the internal relationship between the system's elements in detail. The focus of 
an input-output model is thus on the results of the model, given a set of inputs, and how closely these results represent the real outputs of the system being modelled.

The analytical methods of mathematical programming, production function and input-output analysis have shortcomings regarding certain practical and theoretical problems. The inputoutput model, in its most general form, disregards time as a factor and therefore assumes that relationships and changes in relationships take place at a given moment. Furthermore, although analytical methods have resulted in considerable advancement of traditional logical calculation procedures, the optimising nature of these methods has certain shortcomings regarding certain problems, since it is not always possible to describe some problems analytically or calculate an optimal solution for an analytical problem (Csaki, 1976: 23).

\subsubsection{The positive approach}

When the positive approach is followed, farm-level simulation models, in general, consist of statistical relationships as estimated from historical data, as well as accounting identities that are used to simulate a system in order to find positive answers to "what the likely outcome of the system is'. Basing the system's interrelationships on actual historical behaviour and then making assumptions about the stability of interrelationships in future therefore bases this approach on the argument of attempting to reflect reality as realistically as possible (Strauss, 2005: 18). There are several advantages and disadvantages to using positive models instead of mathematical programming models. The main advantage of the positive models is that they are 'run' rather than 'solved', which implies that the operation and further development of the model is done by means of intensively studying the system through the model and making adjustments to represent the system even more realistically.

The main shortcoming of positive simulation models is the fact that no single optimum solution is obtainable from a typical simulation model. Therefore, all simulations run by such a model are subjective, since the researcher decides on the different alternative options to be simulated (Louw, 1979: 64). 


\subsection{Conclusions}

This chapter has discussed different types of simulation as well as different approaches that can be followed under each model type. The purpose of this study is to develop a tool that will enhance the understanding of the table grape industry under different scenarios; therefore, a descriptive model should be constructed. Furthermore, the model and simulation results will be applied in terms of answering questions to 'what if' scenarios; therefore, the model should be oriented towards behavioural variability. From this, it can be concluded that a deterministic type of model will be built, following a positivistic approach that is based on actual behavioural trends as estimated from actual farm-level data. 


\section{CHAPTER 4}

\section{METHODOLOGY}

\subsection{Introduction}

SATI's new strategy for the table grape industry embodies the industry's desire to expand its export share to the emerging Eastern markets. The adequately diversified export markets are expected to have various benefits for table grape producers, including new trade opportunities due to the opening of alternate markets for table grape producers, increased returns due to properly supplied traditional and emerging markets (i.e. released pressure in traditional markets and consequently relatively stable prices), and enhanced industry growth because of an increasing need to supply both traditional and emerging markets.

In 2008, SATI conducted a survey on table grape producers and exporters to obtain their views about the new industry strategy. The survey findings were presented at a strategic workshop held on 25 August 2008. The survey results indicate that despite the well-known benefits that come with better market diversification, table grape industry stakeholders have different views on the new strategy. These different views can be categorised into three groups: (i) those who fully support the new strategy and believe it must be implemented immediately; (ii) those who partially support the new strategy but think it must not be an immediate action; and (iii) those who think the industry should continue with the current industry's export market distribution. The views of the last two groups are caused by various factors such as lack of understanding of emerging markets, resistance to change (risk aversion) and business models that are only suitable for traditional markets (i.e. comfort zone in traditional markets).

It is the existence of these different views that motivated this study. The study aims to investigate the viability of specific export-market diversification scenarios. Scenario development was selected as the appropriate planning tool to assist table grape industry stakeholders to enhance their understanding of the table grape industry under different scenarios. Furthermore, the study uses a deterministic farm-level model as a tool for simulating and analysing the impact of market changes on the financial viability of farms under different scenarios. 


\subsection{Study method}

Adapting from the methods of well-known scenario practitioners such as Schwartz (1991), Wack (1985) and Van der Heijden (1996), and also drawing on the previous South African scenario development exercises of Van Zyl (2007), the BFAP (2008) and the IDG (2002), the scenarios were evolved in several stages (see Figure 2 in Chapter 2). Firstly, in consultation with South African table grape industry stakeholders, a focal issue taken as the research question to be addressed was defined as follows:

Given the current market situation where traditional markets show signs of becoming saturated due to growing supply by other southern hemisphere countries, what is the potential impact on the industry if the export volumes are to be relocated from traditional to emerging markets, and what would happen if the industry maintained the current market distribution?

The focal issue was then discussed with the industry leaders (executive director and chairman of the South African table grape industry - SATI leaders at the time of consultation) and examined to ascertain if it was in line with the industry's vision and priorities. The time frame was then set, based on the industry's strategy to facilitate the market diversification process over the next twenty years (SATI, 2008: Industry Strategy).

Secondly, a number of factors relevant to the focal issue were identified. The factors relevant to creating a stable and prosperous table grape industry include: (i) sustainable viticulture practices (i.e. cultivar innovation, environment, labour management and efficient use of farm resources); (ii) industry transformation/empowerment; (iii) improved food security and quality standards; (iv) quality industry information (intelligence); (v) industry defragmentation (develop Fruit SA brand); (vi) economic and population growth (domestic and international); (vii) globalisation and urbanisation; (viii) trade policies (market access and non-tariff measures - protocols); (ix) energy crises (i.e. shipping costs and carbon foot print); (x) rising export volumes from the southern hemisphere (grape volumes and price trends) and (xi) innovative packaging to increase comparative advantage.

Thirdly, the factors identified in step two were evaluated and classified either as positive (stimulate prosperous grape industry) or negative (deemed to be a barrier to the grape industry's future). These were arranged in a matrix of high/low impact and 
predictable/unpredictable factors. Factors deemed to have a high impact as well as being highly unpredictable were adopted as driving forces for the scenarios. Four driving forces (grape prices and exporters' attitudes to focusing on Eastern markets, globalisation, rising export volumes from southern hemisphere countries and industry intelligence information) were identified in this way, and in order to deal with these driving forces in a manageable manner, they were divided into two clusters (see Figure 4, below). The matrix diagram below graphically presents the two clusters deemed highly unpredictable.

At this stage, it was clear that the study would have three scenarios in order to accommodate the views of different industry stakeholders: (i) Scenario 1, which is driven by current trends and presents the continuation of current market conditions (i.e. 85\% of South African exports is marketed in Europe and the other $15 \%$ is distributed to other global markets); (ii) Scenario $2 \mathrm{~A}$, which is driven by globalisation, product differentiation and grape prices. Under this scenario export volumes are slowly redistributed to emerging markets. The target is to export $60 \%$ of South African volumes to the EU and $40 \%$ to other global markets by the 2020 season; and (iii) Scenario 2B, which is driven by rising export volumes, declining grape prices, exporters' positive attitudes to change, stringent quality and food safety regulations and improving industry information. Under this scenario, where export volumes are redistributed to emerging markets at a faster rate compared with Scenario $2 \mathrm{~A}$, it takes nine years to achieve the targeted volume distribution, which is $60 \%$ to the EU and $40 \%$ to other global markets.

The literature on scenarios warns against developing three scenarios, as people often tend to then select the middle one, and treat it as a single-point forecast (Bood and Postma, 2008: 6). This study develop two scenarios which is Scenario 1 and Scenario 2A that depict the inadequately and adequately diversified market situations respectively. The third scenario (i.e. Scenario $2 B$ ) evaluates the time factor on market diversification process, however this particular scenario remain similar to Scenario $2 \mathrm{~A}$ in terms of purpose, characteristics and driving forces. 


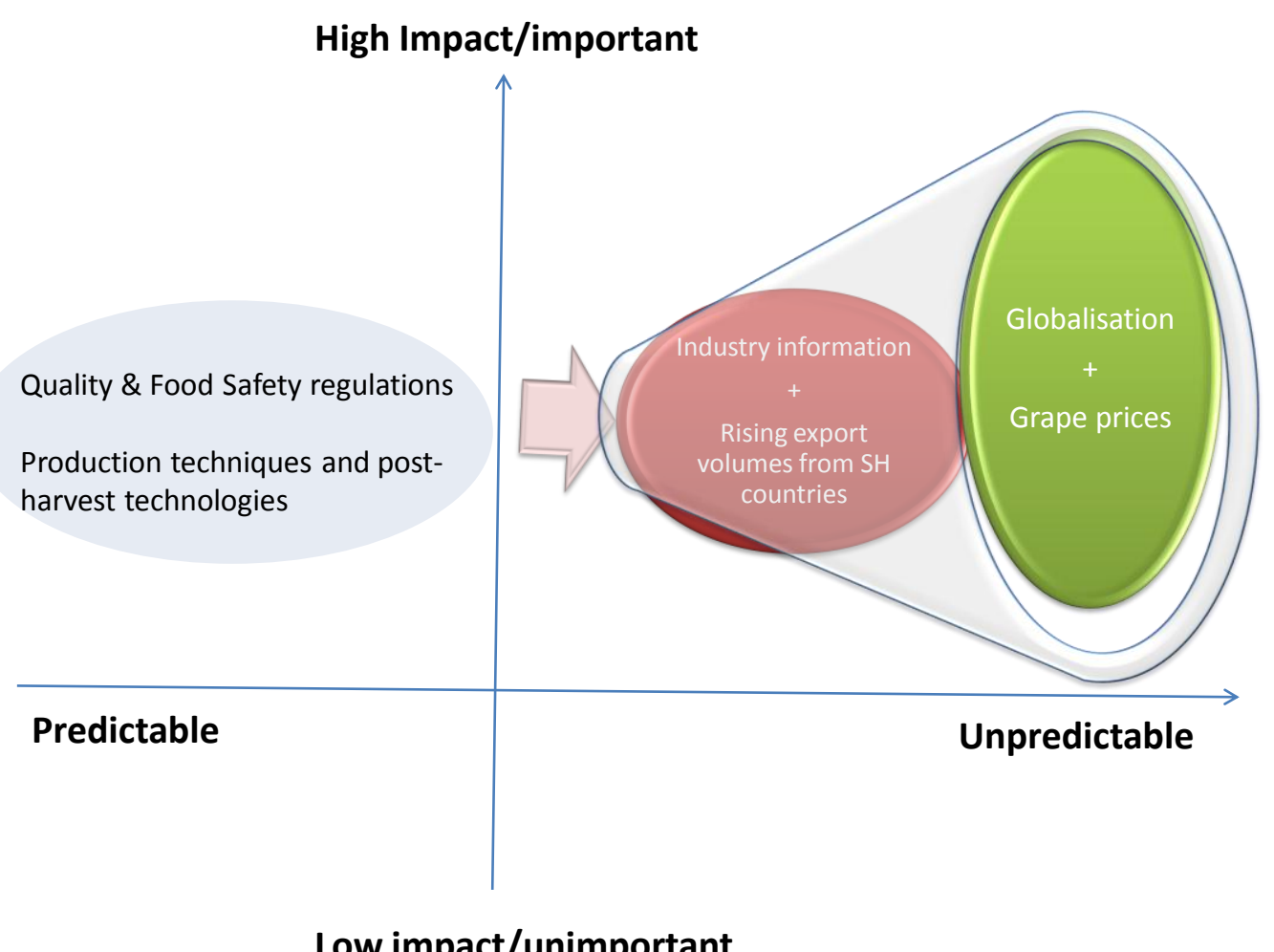

Low impact/unimportant

Figure 5: The basic matrix

Source: Author

The next step was to extrapolate 'future worlds' from both existing data and previous studies in an attempt to understand international markets (see chapter 6: market descriptions). In this phase, driving forces and other pertinent factors were brought into play in a more rigorous manner. This enabled stakeholders to understand the differences between traditional markets and emerging markets. The Eastern markets are economically, psychologically, environmentally and socially different from the traditional markets, and therefore, gaining an improved understanding of these differences is be a key tool in enhancing the stakeholders' capacity to supply these markets successfully.

For scenarios to be effective, they have to change stakeholders' view of reality. The seventh chapter quantifies these driving forces and expresses their influence in numerical terms. The positivistic farm-level model was used to evaluate the impact of changes in markets on farms under different scenarios. 


\subsection{Models used to determine farm profitability}

In chapter two, background information on farm-level modelling and simulation was discussed. The models are built to determine the impact of changes in the markets on the financial viability of farms. This study adopts a deterministic model type in which the probabilities of the different model variables' values are one, and in which the system relationships are constant. The deterministic type of model was built, following a positivistic approach based on actual behavioural trends as estimated from actual historical farm-level data. The models and their simulated results should complement the storyline component discussed in chapter six by presenting numerical estimates of future indicators and helping to maintain the consistency of the storyline of each scenario.

\subsubsection{Farm-level model}

The farm-level model is a multi-period financial model that is built based on accounting principles. The objective of this farm-level model is to simulate and analyse the impact of changes in markets on the financial viability of the farms under different scenarios, in other words, to determine the profitability of farms under each scenario. The model is designed to be sensitive to market changes (e.g. cultivar demand changes); therefore, it has some adaptability elements for certain production parameters, such as establishment costs, production yield and planting material.

\subsubsection{Descriptions of typical farms used in the models}

The main reason for using a typical farm structure instead of an average farm structure is that a typical farm structure represents a more realistic and practical situation, while an average farm is difficult to find in a real world and does not reflect the realistic farming situation. The statistical evidence (i.e. SATI vine census conducted in 2007 and 2008) and forum discussions with table grape producers from different regions suggest that a typical farm in the Northern region is different from a typical farm in the Western Cape region. The main differences are (i) climatic conditions and soil characteristics that lead to different harvesting periods, and consequently different farm prices; (ii) production cost structures and production tactics. These differences resulted in the adoption of two typical farms in this study, one farm representing a typical table grape farming unit in the Western Cape area; the other reflecting a typical table grape farming 
unit in the Northern region. Based on the SATI vine census report (2007 and 2008) and forum discussions with table grape producers conducted in 2009, a typical farm in the Northern region has the following cultivar composition in order of importance: Prime Seedless, Thompson Seedless, Red Globe, Flame Seedless, Crimson Seedless, Moonballs, Black Gem and Midnight Beauty. Typical farm size in the Northern region is 65 hectares, $87 \%$ of this being under cultivation of table grapes, with the rest catering for roads, houses, storage and pack houses.

A typical farm in the Western Cape areas has the following cultivar composition in order of importance: Dauphine, Sugraone, Barlinka, Thompson Seedless, Red Globe, Crimson Seedless, Victoria, Sunred Seedless, La Rochelle, Autumn Royal, Midnight Beauty and Alpha Red. Typical farm size in the Western Cape is 46 hectares, $85 \%$ of this being under cultivation of table grapes, with the rest catering for roads, houses, storage and pack houses. The Western Cape farm represents three table grape production regions, namely Berg River, Olifants River and Hex River, while the Northern region farm represents the Orange River and Northern Province regions (see Annexure A for the typical Western Cape farm and Annexure B for the typical Northern region farm).

\subsubsection{Type of data used and data collection process}

Like other fruit sectors in South Africa, the table grape industry lacks credible historical data due to the industry fragmentation process that occurred after market deregulation in 1997. In 2005, the table grape industry started to restore the credibility of industry data by prioritising the collection and monitoring of it (e.g. production and export trends, production costs and grape prices).

The models require various types of data, including (i) production and export time-series data; (ii) directly and indirectly allocatable production costs at the farm level; (iii) vine establishment costs at the farm level, and (iv) grape price time-series data. The production and export data was sourced from PPECB (Perishable Product Export Control Board) and SATI, as they were in charge of monitoring and managing table grape production and export data since deregulation. The production costs (e.g. directly and indirectly allocatable costs) and grape price data were sourced from Frudata, a consulting company that monitors production costs and grape price changes across the industry. The grape price data was then discussed with various table grape exporting companies to verify its credibility. The same was done for production cost data for the various table grape producers from all five production regions,. 
With regard to future table grape prices, production costs and export quantity data, the historical data from PPECB, Frudata and SATI was then processed to provide extrapolations. The results were discussed with various industry experts (including exporting companies, chemical companies, producers and industry consultants from commercial banks). Their opinions about how they saw the industry in the next 20 years were then incorporated into the extrapolations. The modified extrapolations were then sent back to the industry experts for review, and they were requested to inform the author about whether they thought the extrapolations provided realistic projections of the future. The final result was analysed to evaluate and identify any discrepancies. The data provided in Annexure A and Annexure B represent a true reflection of data collected for the Western Cape and Northern region farms respectively.

\subsubsection{Assumptions in the farm-level model}

The farm-level model is calculated over a 20-year period (i.e. multi-period financial budgeting) to accommodate the replacement process of less-profitable cultivars for the Eastern markets with new popular cultivars that are in high demand in both Eastern and European markets. The lengthy period also allows the model to evaluate the benefits (e.g. high expected export price) that emerge from producing and exporting popular cultivars with the desired characteristics.

The hypothesis for this study is to develop a financial model based on accounting principles, and the model should be sensitive to changes in market demand trends in order to evaluate the profitability of farms under various scenarios (e.g. it must show the effect of replacing lowdemand cultivars with new highly popular cultivars). With this in mind, assumptions were made that all farm cultivars are established at once (i.e. year one), and the number of hectares under production on each farm remains constant for the entire 20-year period. This means that on the Western Cape farm, 39 hectares are used to produce table grapes, while on the Northern region farm, 57 hectares are used to produce table grapes (see Annexure A: Table 1 for land utilisation per cultivar on the Western Cape farm, and Annexure B: Table 1 for land utilisation per cultivar on the Northern region farm). Furthermore, the assumption was made that under Scenario 1, no replacement will take place, as the industry maintains the current market distribution. Therefore, on both Western Cape and Northern region farms, all cultivars are established in year one and retained for the entire 20-year period. 
Under Scenario 2A and 2B, all farms' cultivars are established at once (i.e. year one), and the replacement of cultivars that have low demand or popularity in the Eastern markets are replaced by those cultivars with high demand in both Eastern and European markets. Therefore, this means that even if cultivars are only five years old from the establishment year (which is year one), they will be replaced if they have low demand or popularity in Eastern markets.

To determine the popularity and medium-term potential of cultivars in European and Eastern markets, an export guide from Capespan was used. This export guide evaluates the market potential of cultivars in global markets based on market requirements, consumer characteristics and realised market prices. Based on this export guide and PPECB export trends, it was revealed that Western Cape farm cultivars like Dauphine, Victoria, Alpha Red, Barlinka and La Rochelle are in low demand and are not popular in Eastern markets. However, some of these cultivars are in noticeable market demand in European markets. Therefore, these cultivars will have to be replaced with new cultivars such as Midnight Beauty, Autumn Royal, Crimson Seedless and Sugraone if the industry wishes to expand its export share to Eastern markets .

On the Northern region farm, it was shown that cultivars such as Moonballs, Thompson Seedless and Black Gem have and will continue to be in low demand in Eastern markets. This suggests that Northern region farms should replace these cultivars with new cultivars, such as Prime Seedless, Flame Seedless, Crimson Seedless and Red Globe, with the desired characteristics, if the industry wishes to expand its export volumes to Eastern markets (see Annexure B: Table 2 for cultivar replacement planning on the Northern region farm under Scenario 2A, and 2B).

The cultivar replacement process under Scenario 2A is slow to allow exporters to understand the trends and characteristics of Eastern markets. The effect of replacement costs for each cultivar on the farm is shown using the gross margin, and the positive impact of planting new popular cultivars only becomes noticeable after two years reckoned from the replacement year (see Annexure E for the Western Cape farm, and Annexure F for the Northern region farm under Scenario 2A). Though it is general knowledge, it should be emphasised that with table grape farming, the replacement process only takes one year, meaning unwanted vines are uprooted in March/April and new vines are planted in August/September of the same year. This is different from wine farming, where the replacement process takes up to three years (unwanted vines are uprooted and the land is left unused or planted with vegetables for three years before replanting new vines on the same land). 
The replacement process and its impact on the farm's financial viability for Scenario 2B was simulated using the same procedure as for Scenario 2A. The replacement process for Scenario 2B was faster than for Scenario 2A (see Annexure $G$ for the Western Cape farm and Annexure H for the Northern region farm). As for Scenario 2A, the effect of replacement costs of each cultivar on the farm was shown using the gross margin, and the positive impact of planting new popular cultivars only becomes noticeable after two years from the replacement year.

\subsubsection{Simulation process and structure of the farm-level model}

The model is simulated over 20 years, and the data discussed in Section 4.3.1.2, above, was used to feed the model in order for the model to operate. The farm-level model takes into account production yield, realised export price at delivered-in-port (DIP) level, marketing costs, establishment costs, directly allocatable variable costs, indirectly allocatable costs and fixed and intermediate farm capital.

Firstly, the gross margin per cultivar on the farm is calculated individually. Secondly, the model calculates the farm's gross income, which is the sum of gross margins per cultivar on each farm. Thirdly, the impact of indirectly allocatable costs such as labour, electricity and fuel prices were incorporated in the model, and the farm margins, before capital expenditures, were calculated. This was done to determine the farm's returns before including the farm's capital costs. Fourthly, the impact of long-term and intermediate farm capital was incorporated in the model. From these four steps it is possible to calculate farm cash inflow (i.e. gross income) and farm cash outflow (i.e. indirectly allocatable costs and farm capital costs). The net cash flow was then used to calculate the internal rate of return (IRR) and the net present value (NPV). The current inflation and interest rates were sourced from the Reserve Bank and the commercial banks. For the complete structure of a farm model under different scenarios, see Annexure C-H

The IRR is used as a performance indicator for both farms under each scenario. The IRR of an investment is defined as the interest rate at which the costs of the investment lead to the benefits of the investment (Van Zyl et al., 1999: 207). This means that all gains from the investment are inherent in the time value of money and that the investment has a zero net present value at this interest rate. The higher a scenario's IRR, the more desirable it is to implement the scenario. As such, IRR can be used to rank several prospective scenarios for an industry. Assuming all other factors are equal among the various scenarios, the scenario with the highest IRR would probably be considered the best and undertaken first (see Annexure C: Table 1, Annexure D: Table 1, 
Annexure E: Table 1, Annexure F: Table 1, Annexure G: Table 1 and Annexure H: Table: 1 for the IRR of each farm for all three scenarios).

\subsubsection{Sector model}

The farm-level models for the Western Cape and Northern region farms were linked to form a sector model. The general objective of a sector model is to evaluate the effect of changes in market distribution on the table grape industry at large. The sector model quantifies and determines whether the table grape industry value (i.e. the worth of the industry) and export volumes expand under Scenario 2A and 2B, when compared with Scenario 1.

The following diagram (see Figure 6, below) reflects the structure of the sector model. The volumes exported were classified using grading criteria such as percentage of Class 1, which represents premium quality, Class 1.5, which represents medium quality, and Class 2, which represents low quality. The industry export volumes include quantities produced and exported from all five South African production regions.

The weighted average export price for major South African export markets (i.e. Continental EU, UK, Middle East, Far East and Africa) was used in the sector model. The price was captured at a free-on-truck (FOT) level and monitored back to a delivered-in-port (DIP) level. All parameters involved in the fresh supply chain between FOT and DIP levels were identified and quantified. Figure 6, below, shows all export costs that take place when exporting table grapes to various markets and provides an analysis from a market perspective back to the farm level. 


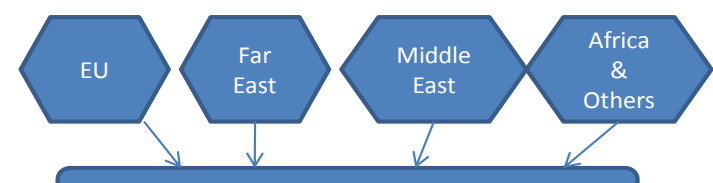

Weighted Average Gross Price

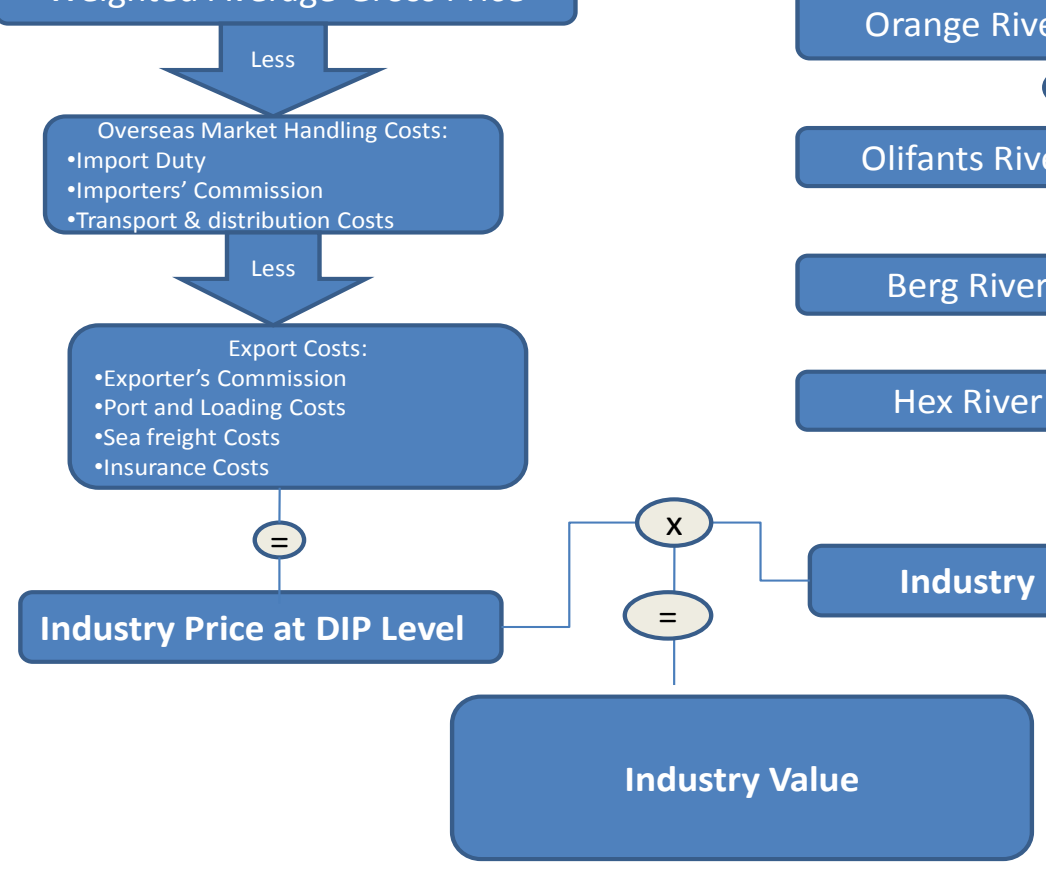

Figure 6: Structure of the sector model for the table grape industry

Source: Own manipulations based on OABS (2007) and Vinpro (2007 and 2008).

The model is calculated over 20 years to accommodate the replacement of old non-profitable cultivars with new popular cultivars, and to monitor the benefits that emerge from producing and exporting popular cultivars (see Annexure I: Tables 1 to 3 ).

\subsection{Conclusions}

The study adopted scenario planning as a tool to investigate the viability of expanding South African table grape export volumes to Eastern markets as well as the potential risk of retaining the current market distributions. It uses financial farm-level modelling to determine the profitability of farms under each scenario developed. The financial farm model makes use of the IRR as the farms' performance indicator under each scenario developed. The IRR is used to rank several prospective scenarios, assuming all other factors are equal among the various scenarios. The scenario with the highest IRR would probably be considered the best and undertaken first. 


\section{CHAPTER 5}

\section{BACKGROUND INFORMATION ON THE SOUTH AFRICAN TABLE GRAPE INDUSTRY}

\subsection{Introduction}

From its birth in the 1880s, the South African table grape industry has become an important contributor to the South African economy, both directly, through foreign earnings from this predominantly export-based industry, and indirectly through the creation of employment. The first table grape variety (Muscat d` Alexander) was planted in the Hex River Valley, (Robertson area) and was the first grape variety to be exported from South Africa to the UK in 1886 (Burger, 2002: 18). In 1890, Percy Alport Molteno, the manager of Castle shipping company, and his brother decided to establish the export company, Cape Fruit Syndicate in Cape Town (Burger, 2002: 18). In June 1892, Cape Fruit Syndicate had already exported 2100 cartons of table grapes, 6000 cartons of apples and a single carton of pears. In 1892, Leicester Dicey, Fred Strulen and Percy Malleson established the Cape Orchard Company in the Hex River Valley, buying fruit from Hex River producers (Burger, 2002: 18).

The deciduous fruit industry attained its first success in 1892, though its knowledge of the right kinds of cultivars, the most suitable packaging and the best temperatures at which to ship the fruit was still limited. The early pioneers of the Cape Fruit Syndicate, the Cape Orchard Company, and others who followed in their footsteps learnt their lessons fast. By the end of the full export season of 1892, Percy Molteno published a pamphlet with advice to packers, based on the Syndicate's experience. He also reported on the grape cultivars preferred by buyers and consumers in the overseas market (Burger, 2002: 19).

The arrival of the nurseryman Harry Pickstone in 1892 marked the take-off of the deciduous fruit industry. Pickstone had studied nursery practices in Southern California and established his first nursery in South Africa on the Nooitgedacht farm. Numerous vines were imported and grafted in this nursery, and new cultivars were then released to the industry for planting. In 1899, table grape volumes had grown to 12000 cartons, and the main cultivars harvested were Muscat d Alexander, Waltham Cross and Almeria. In 1910, the black variety Barlinka was imported, a 
cultivar that proved to be of great value to the industry because of its resistance to harsh weather conditions (Burger, 2002: 19).

The industry realised the importance of pre-cooling fruit and started using the first pre-cooling chambers in the Cape Town port in 1925. The Perishable Products Export Control Board (PPECB) was established in 1926 and was responsible for quality control of all perishable agricultural export products (Tregurtha and Vink, 2002: 7). Under the old Agricultural Marketing Act of 1937, Deciduous Fruit Board was established to modernise and strengthen farming after the depression's adverse effect on many fruit farmers (Fundira, 2003: 7). The Act gave Fruit Board power to fix prices of their products and to gazette regulations of the overall control of the marketing of these products (Fundira, 2003: 7). By the 1946/47 fruit season all fruits were exported under a common label with bulk of the crop being sold in the UK (Tregurtha and Vink, 2002: 7). The real marketing changes came about in the early 1970s when control over the domestic marketing of fresh fruits was abolished and export marketing power was delegated from the Deciduous Fruit Board to Universal Fruit Trade (Co-operative) Limited (Unifruco) in 1986 (Tregurtha and Vink, 2002:7). Unifruco was responsible for marketing of fruits and held this position until 1996 before the deregulation era. In 1996, a new Agricultural Marketing Act was passed, which brought many uncertainties and an unfamiliar new dispensations (Fundira, 2003: 7). This led to a number of new initiatives such as the Fresh Produce Exporters' Forum in 1999 and South African Table Grape Industry in 2005.

\subsection{Description of South African table grape production regions}

South African table grapes are cultivated in five production regions, namely, Orange River, Berg River, Hex River, Olifants River and Northern Province.

Orange River: This region is currently the second-largest producer of table grapes in the country. The cultivation of grapes in the lower Orange River area first made headway in the 1940s. The 1970s are considered the golden era in the history of table grape farming along the Orange River, with the completion of the Gariep dam (formerly known as the Hendrik Verwoerd dam) in 1972 and the Van der Kloof dam (previously known as PK le Roux dam) in 1977. Thousands of hectares of arable land along the riverbanks became available for farming using irrigation from the stabilised Orange River (Burger, 2002: 22). Many of the farmers along the lower Orange River who traditionally cultivated Sultana grapes for wine and raisin production 
were encouraged to adjust their vineyards for production of Sultana Seedless. The 1982/83 season was the start of South African exporting of seedless table grapes, and by 1985, a total of 65000 cartons were exported from the lower Orange River (PPECB, 1986). The Orange River is the second-earliest region to commence harvesting grapes in South Africa. The region is dominated by seedless varieties (accounting for more than $87 \%$ of total hectares), which are exported to continental Europe and the UK to obtain premium prices in the weeks prior to the Christmas period. The region (see Figure 7, below) is considered one of the most profitable regions in the country (SATI, 2008a).

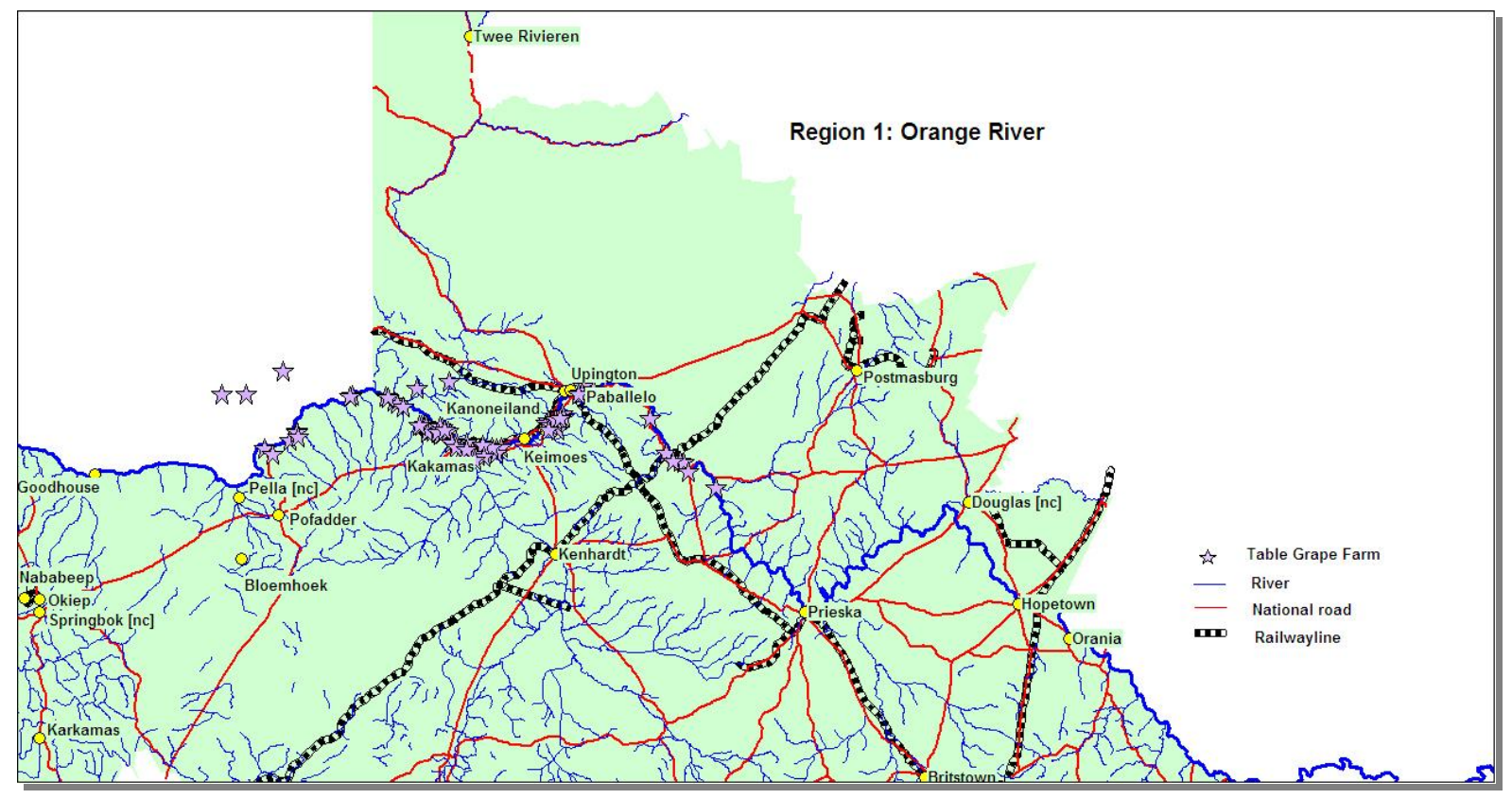

Figure 7: Location of table grape farms in the Orange River region

Source: SATI, 2008a

Berg River: This region is the third-largest producer of table grapes in South Africa. The main reason for the concentration of table grape vineyards in the coastal zone around Paarl is probably its closer proximity to Cape Town harbour $(60-70 \mathrm{~km})$ and packaging material manufacturing companies, as well as the relatively high prevailing temperatures. The importance of heat summation in the coastal zone in order to ensure an early harvest, and consequently, better prices is demonstrated by the absence of table grapes in the cooler Stellenbosch areas. Weather conditions in the Berg River region range from relatively dry in the Piketberg area to wetter conditions in the Paarl area. The Berg River (see Figure 8, below) has a well-balanced cultivar 
mix (seeded and seedless), which enables the region to supply markets with different requirements and characteristics (SATI, 2008a).

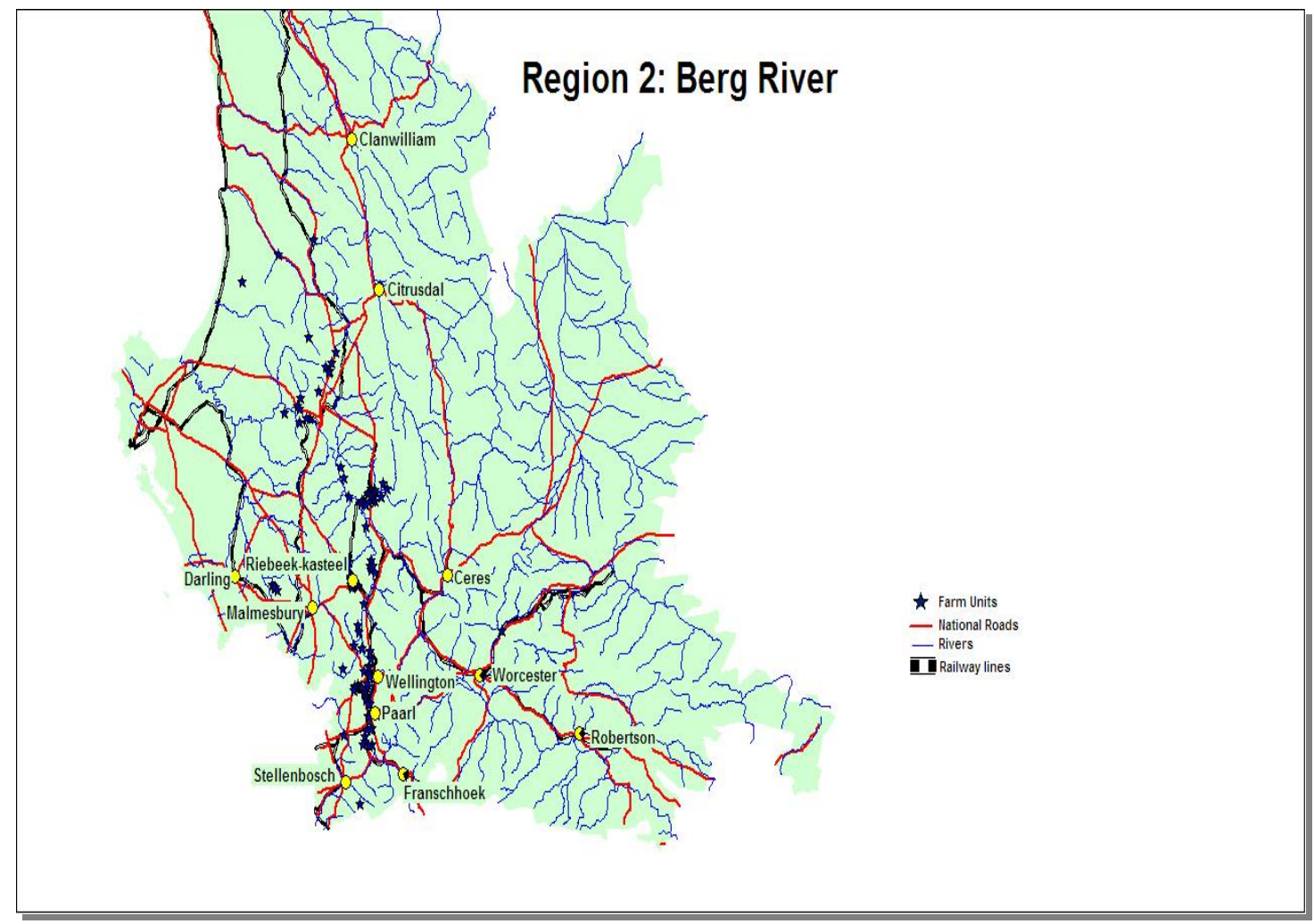

Figure 8: Location of table grape farms in the Berg River region

Source: SATI, 2008a

Hex River: This region is the oldest and largest producer of table grapes in South Africa. A railway line was constructed through the Hex River Valley during the late $19^{\text {th }}$ century to link the Cape and the prospering mining towns in the north. This stimulated demand for fresh fruits and motivated table grape production in the isolated valley, dating back to the 1880s (Burger, 2002: 19). The Hex River Valley (see Figure 9, below) has a favourable, relatively dry climate for table grape production. The region enjoys a Mediterranean climate, receiving moisture from the Atlantic Ocean during the winter months. The warm, dry summer air ripens the grapes to sweet perfection. It has the longest table grape harvesting period in the country, starting at the end of January and finishing in May with the packing of the Dauphine cultivar. 


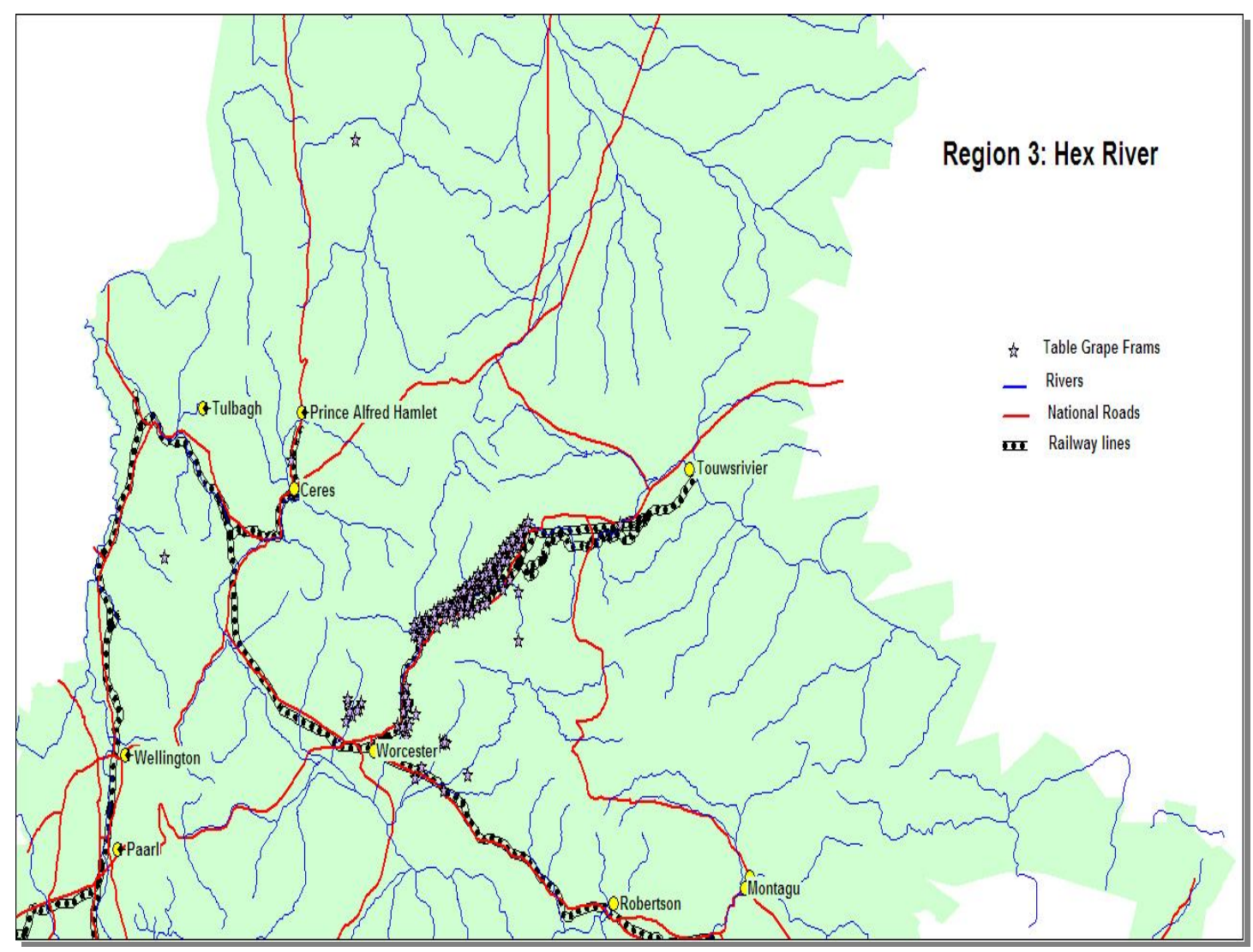

Figure 9: Location of table grape farms in the Hex River region

Source: SATI, 2008a

Northern Province: This region is the fourth-largest producer of table grapes in the country. The development of grape vineyards in the inland summer rainfall areas such as Groblersdal, Brits, Ellisras and Potgietersrus was the result of the innovative spirit of individual growers who recognised the market potential of Johannesburg, Pretoria, and the Vereeniging mining and industrial centres, and later, the export markets (Burger, 2002). The high temperatures ensure an early budding, flowering and harvesting time, resulting in good prices. The table grape industry provides more than 2000 permanent farm jobs and about 4300 part-time farm jobs (SATI, 2008a). See Figure 10, below. 


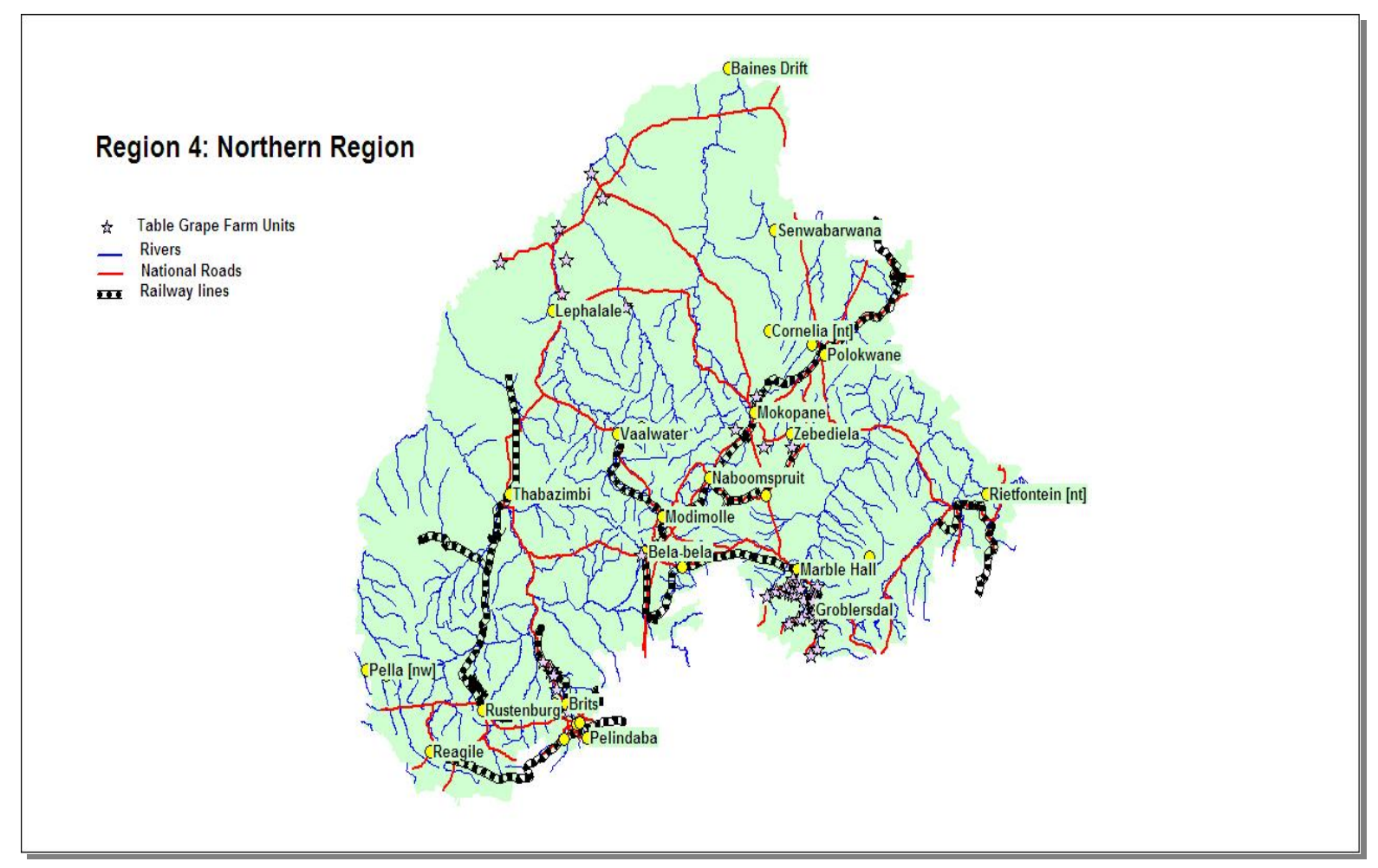

Figure 10: Location of table grape farms in the Northern Province region

Source: SATI, 2008a

Olifants River: This region, classified as a desert or semi-arid region, is the smallest producer of table grapes in the country and can be seen as intermediate between the Orange River and Berg River regions. Table grape production increased rapidly in the last few years because many of the traditional raisin and wine farmers turned to table grape production. The region is dependent on water from the Olifants River Irrigation Scheme, since rainfall is scarce in the region. In the 2007/8 season, a total of 1.8 million cartons were packed for export, contributing $4 \%$ to South African production. Major cultivars harvested from this region include Red Globe, Thompson Seedless, Flame Seedless, Sugraone and Crimson Seedless (SATI, 2008a). See Figure 11, below. 


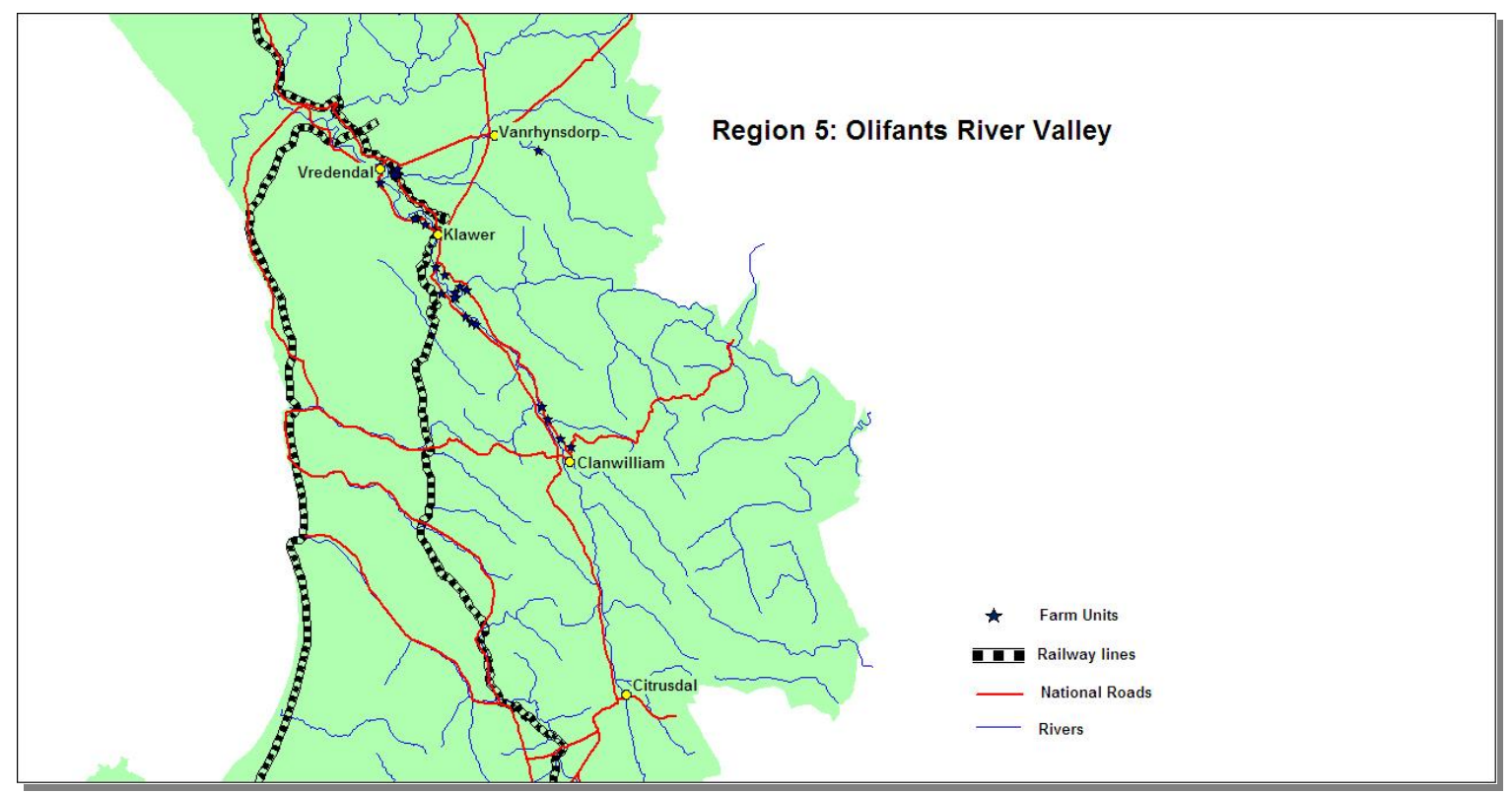

Figure 11: Location of table grape farms in the Olifants region

Source: SATI, 2008a

These regions differ in terms of geographical allocations, soil characteristics and climate, which sees South Africa enjoy a long season from November till late May. The diverse climates allow South Africa to cultivate different varieties that meet the demands of different international markets. The top table grape cultivars planted in South Africa and their percentages of total hectares occupied are as follows: Red Globe $-10 \%$, Thompson Seedless $-10 \%$, Crimson Seedless $-10 \%$, Prime Seedless - 9\%, Sugraone - 9\%, Flame Seedless - 9\% and Dauphine $8 \%$ (SATI, 2009). More than 13\% of total hectares are planted to grapes that are not yet in full production (new plantings); these vines are expected to be in full production within the next three seasons (SATI, 2008a).

\subsection{The competitiveness status of the South African agribusiness sector and the table grape industry}

This section aims to define and describe the competitiveness status of the South African agribusiness sector. This section borrows heavily on the work done by Dirk Esterhuizen, who evaluated the competitiveness status of the South African agribusiness sector. The issue of competitiveness has become important for agribusiness managers and strategic planners as their business need to compete locally and internationally under highly competitive environments. 


\subsubsection{Defining competitiveness}

Competitiveness is define as the effort of a firm or industry to sustain or increase its market share, through appropriate pricing strategies, product quality improvement, the use of adaptable marketing strategies, etc. (Oustapassidis et al., 1993). It can also be define as the ability of a sector, industry, or firm to compete successfully in order to achieve sustainable profits and growth within the global environment while earning at least the opportunity costs of returns on resources employed (Esterhuizen, 2006: 139). The second definitions contains elements of competitive and comparative advantage. It is therefore, important to note that comparative advantage does not mean competitive advantage, but it can be the basis on which to build competitive advantage (Khemani, 1997 and Jooste, 2009).

\subsubsection{Measures of competitiveness}

Researchers have mainly used two scientific approaches to measure and analyse competitiveness, namely models and indicators (Esterhuizen, 2006: 100). Models are complex and are usually custom-build to answer specific questions. Models require a relatively large investment in data collection and analysis. As a result, they are appropriate primarily for academic research or high-stake investment decisions and policy choices (Esterhuizen, 2006: 100). The main alternative to models is index-number indicators, design to measure some change over time or comparison across industries (Esterhuizen, 2006: 100). Like the Consumer Price index of inflation, such indicators do not pretend to simulate the economy itself, they serve as thermometers or barometers, not weather forecasters. The quality of the results obtained with these indicators depends to a considerable extent on the quality of the data available. The quality, type, and amount of data required also vary between the measures, the choice of the method to be used is therefore often dictated by data availability (Esterhuizen, 2006: 101).

One important aspect of competitiveness is that it is a relative measure. There must always be a comparison with a base value. If, for example, market share is being assessed, it must concern market size (Esterhuizen, 2006: 100). Esterhuizen (2006) define and describe a variety of other methods that can be used to measure competitiveness. To determine the competitiveness of the South African agribusiness sector, Esterhuizen (2006) select the Relative Comparative Advantage (RCA) model that was developed by Balassa in 1977 and extended by Volrath in 1991 to the Real Trade Advantage (RTA) method. See Esterhuizen (2006: 116-122) for description and development of RTA method. The RTA method measures competitiveness based 
on the ability to sustain trade. It can indicate the state of competitiveness, and ensure proper understanding of underlying factors such as trade restrictions, growth in local market and climate events. However, a limitation of RTA is that it does not explain how country or region acquired its global market share and competitiveness status. Market share may be well be attained by means of high export subsidies paid by governments (Esterhuizen, 2006: 154).

\subsubsection{Competitiveness status of the South African agribusiness sector}

In Table 3 and Figure 12 the competitiveness status of the agribusiness sector in South Africa is shown. From the table and figure it is evident that the South African agribusiness sector's RTA values are situated round-about zero $($ RTA 2003 value $=0.55$; RTA 2002 value $=0.46$; RTA 2001 value $=0.48$ ). This results classifies the South African agribusiness sector as being generally marginal as far as international competitiveness is rated (Esterhuizen, 2006: 149). However, the competitiveness of the agribusiness sector recorded relatively positive trends in competitiveness from 1961 to 1973; from 1985 to 1990 and the first decade after democratic elections (Esterhuizen, 2006: 149).

The trends in the competitiveness of the agribusiness sector in South Africa from 1961 to 2003 can be divided into five phases (see Figure 12 and Table 3). The first phase is during the 1960s and early 1970s. South Africa's agribusiness sector was relative competitive, with RTA values above one. This was mainly as results of relatively low interest rates and low inflation. Subsidies and high protection from government also contributed to making the sector more competitive during this period (Esterhuizen, 2006: 149).

The second phase is from the mid-seventies to the mid-eighties. Sanctions were introduced in this period that resulted in a large drop in competitiveness. Interest rates were also relatively high. Also during this period the marketing of agricultural products were regulated by marketing boards. Note also the negative impact of the drought seasons of 1973/74, 1978/79, 1983/84 and 1984/85 on the competitiveness of the agribusiness sector in South Africa (Esterhuizen, 2006: 149). 


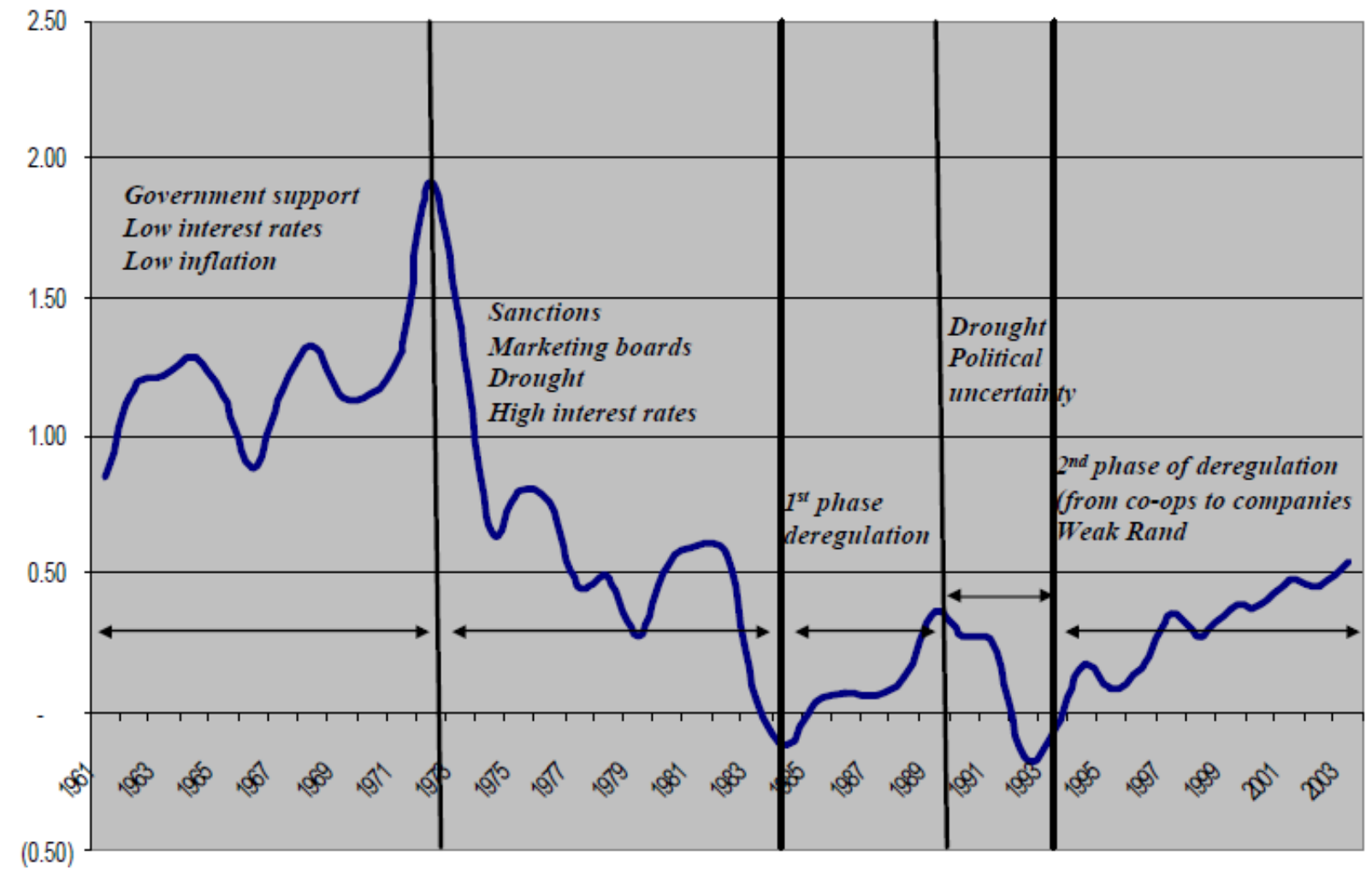

Figure.12: The competitiveness status of the South African agribusiness sector

Source: Esterhuizen, 2006: 150

The third phase is from the mid 1980s to early 1990s. The slight increase in the competitiveness of the agribusiness sector in South Africa can be attributed to the first phase of deregulation that was introduced. The fourth phase is the sharp decline in competitiveness in the early 1990s that was because of the drought and the political uncertainties before the first democratic elections in South Africa (Esterhuizen, 2006: 151).

Table 3: The competitiveness of the South African agribusiness sector

\begin{tabular}{|l|l|l|l|l|l|l|l|l|}
\hline & RTA & RTA & RTA & Trends & Trends & Trends & Trends & Trends \\
& $\mathbf{2 0 0 3}$ & $\mathbf{2 0 0 2}$ & $\mathbf{2 0 0 1}$ & $\mathbf{1 9 6 1 - 7 3}$ & $\mathbf{1 9 7 4 - 8 4}$ & $\mathbf{1 9 8 5 - 9 0}$ & $\mathbf{1 9 9 1 - 9 3}$ & $\mathbf{1 9 9 4 - 0 3}$ \\
\hline $\begin{array}{l}\text { The South African } \\
\text { agribusiness sector }\end{array}$ & 0.55 & 0.46 & 0.48 & + & - & + & - & + \\
\hline
\end{tabular}

Source: Esterhuizen, 2006: 150 
The fifth phase is the definite positive trend in the competitiveness of the agribusiness sector in South Africa from 1992 to early 2000s. The competitiveness index for the South African agribusiness sector increased from -0.16 in 1992 to 0.55 in 2003 . This positive trend occurred despite the ever more decreasing terms of trade (Esterhuizen, 2006: 151). The period from 1992 also indicates the start of the sharp and continuous decrease in the value of the Rand against the US\$. Although the devaluation of the Rand plays an important role in making the prices of South African products more competitive, this is not the only reason for the improvement in competitiveness. This increase in competitiveness can also be attributed to the improved business know-how of South African agribusinesses; the second phase of deregulation of the agricultural sector, which amongst others resulted in a change in business form from co-operative to companies; the elimination of non-competitive business; the delivery of quality products and an increase in labour productivity in the agribusiness sector (Esterhuizen, 2006: 151).

\subsubsection{Competitiveness status of the South African table grape industry}

Esterhuizen (2006) evaluated the competitiveness status of fifty seven selected agricultural commodities and processed chains. For the scope of this study, only grape chain will be discussed in the this segment. The grape chain include table grapes, grape juice and dried grapes. Table 3 illustrates the competitiveness status of the South African grape chain and products under this chain..

Table 4: The competitiveness of grape chains in South Africa and trends in competitiveness from 1961 to 2002 based on the Relative Trade Advantage (RTA) index

\begin{tabular}{|l|c|c|c|c|c|c|c|c|}
\hline Chain & Product & RTA & RTA & RTA & Trends & Trends & Trends & Trends \\
& & $\mathbf{2 0 0 2}$ & $\mathbf{2 0 0 1}$ & $\mathbf{2 0 0 0}$ & $\mathbf{1 9 6 1 - 0 2}$ & $\mathbf{1 9 8 0 - 0 2}$ & $\mathbf{1 9 9 3 - 0 2}$ & $\mathbf{1 9 9 8 - 0 2}$ \\
\hline Grape Chain & Grapes & 10.59 & 11.84 & 14.57 & + & + & + & - \\
& Grape juice & 5.87 & 5.55 & 7.66 & + & + & + & + \\
& Raisins & 9.88 & 9.16 & 6.92 & + & + & + & + \\
\hline
\end{tabular}

Source: Esterheuizen, 2006: 157 
From Table 4 it is evident that South Africa's grape chain has been highly competitive internationally, but the primary product (table grape) is more competitive than the processed products (i.e. grape juice and raisins). Table grape show positive trends in competitiveness in the long term, expect for the period between 1998 to 2002. Grape juice and raisins have positive trends in competitiveness in the long term, as well as in the short term (Esterheizen, 2006: 167). From the trends shown in Table 4 above it can be established that table grape industry has been successful up to the late 1990s. The findings of Esterhuizen (2006).are supported by BFAP (2008) study. The decline in competitiveness of the South African table grape industry as from the early 2000s can be attributed to rising competition from alternate South Hemisphere suppliers, increasing production costs and export costs (BFAP, 2008: 3). The negative trends in competitiveness imply that adjustments related to factors influencing the competitiveness status can contribute to changing the status from negative to positive. The following section identifies the particular set of factors that can positively influence the competitiveness of the South African table grape industry.

\subsection{Required changes to remain competitive global suppliers}

The South African table grape industry has evolved significantly in the last two decades. Ever improving supply chain technologies, the emergence of new viticultural techniques, post-harvest technology innovation, more efficient production inputs and new cultivars have all stimulated the production of table grapes in all five South African production regions. While the industry in general is well developed, some areas within the production chain need some adjustments in order to comply with the standards and regulations of both traditional and emerging markets.

In Chapter 4, a number of factors relevant to the focal issue of this study were identified, and table grape producers need to address these factors if they are to remain competitive global suppliers. The factors relevant to creating a stable and prosperous table grape industry include: (i) sustainable viticulture practices; (ii) improved food safety and quality standards; (iii) innovative product packaging and (iv) research development. In the next section, the study discusses these factors and also highlights the route that South Africa needs to take if it is to remain a competitive global supplier in an adequately diversified market situation. 


\subsubsection{Sustainable viticulture practice}

The issue of sustainable viticulture practices includes various aspects such as (i) selection of suitable cultivars for different regions; (ii) efficient management of chemical sprays, labour and fertiliser usage; (iii) optimisation of production yield and (iv) replacement of old cultivars. These are the main determinants of the industry's success. Over many decades, the industry has selected and planted varieties only suitable for European markets. The industry has found itself facing greater challenges to restructuring its production range in order to satisfy consumers' needs in both traditional and emerging markets.

In the last two decades, consumer preferences in Europe, particularly in the UK, changed from seeded to seedless cultivars, which created a large demand for seedless varieties. The South African industry responded by planting large amounts of seedless cultivars in early regions such as the Northern Province and the Orange River. The industry is currently dominated by seedless cultivars accounting for $58 \%$ of total hectares under table grape production, and seeded varieties occupying $42 \%$ of total hectares. The $58 \%$ of seedless vines is mostly white seedless cultivars $(46 \%)$, followed by red seedless $(33 \%)$ and black seedless cultivars (21\%) (SATI, 2009). Some of these seedless cultivars (e.g. white seedless) are no longer profitable in traditional markets and are also not suitable for emerging markets as they lack certain characteristics such as crispy eating quality, sweetness, a longer shelf life and are susceptible to browning and diseases such as Botrytis.

A market study commissioned by SATI and carried out by the Trade Matrix Company in 2005 suggests that there were at the time substantial table grape trade opportunities in emerging markets such as China, India, Vietnam, the Middle East and many other Asian countries (TTM, 2005: 21-23). The study found that Eastern consumers prefer seedless cultivars (e.g. red seedless) because of convenience (no seeds and easy to peel because of large berry size) and their attractive appearance. These findings suggest that South Africa should engage in a strategic vine replacement process in order to improve their product range (i.e. cultivar profile).

The table grape producers will have to strategically replace both seedless and seeded cultivars that are no longer profitable in today's market with new seedless cultivars in high demand in 
both traditional and emerging markets. While global demand for seedless cultivars is growing, continental Europe still has large market opportunities for seeded varieties that have the right cultivar characteristics (longer shelf life, good colour development and eating character, and larger berry sizes). Red Globe is a classic example of a seeded cultivar that is performing well in both traditional markets and emerging Eastern markets, and producers need to retain this cultivar (SATI, 2009). There are seedless cultivars (especially white seedless cultivars) that are losing their popularity in the markets due to problems such as browning, shattering and bunch decay, and these needs to be replaced by new cultivars.

The other issues relating to sustainable viticulture practices are those of sound environment and labour management systems. When South Africa engages in a stronger diversification process to explore and develop alternative markets for their products, current production practices (e.g. intensity of spraying chemicals and applying fertilisers) will be influenced by different markets requirements. The emerging Eastern markets have different environmental management requirements that are regulated by protocols, such as in the case of China. The issues of labour management (i.e. ethical trade) will also become important in the future, as they have already gained momentum in recent years. Though emerging markets have their own set standards with regard to labour and environmental issues, developed markets (e.g. the EU) are well known for having much stricter or higher standards compared to developing Eastern markets. This poses a large advantage to South Africa, as the country has been complying with European standards over many decades. It is evident that experienced South African producers will experience less difficulty in meeting the requirements of emerging markets if they engage in a strong diversification process (Benic, 2008).

\subsubsection{Improved food safety and quality standards}

Over the last eight years, southern hemisphere export volumes have increased significantly. As a result of increasing exports, international markets have strengthened their quality standards and increased their concerns over food safety. The traditional markets have set up stringent quality and safety standards to protect the wellbeing of their consumers. However, South Africa has been able to supply Europe over several years under these tight non-tariff measures. The Eastern markets have more lenient requirements compared to European markets, and South Africa will have less difficulty in complying with these (Benic, 2008). Though South Africa might be a 
leader (at present) in supplying quality table grapes to global markets, significant measures are necessary to ensure sustained production of quality grapes.

\subsubsection{Research developments}

In 2000, the National Agricultural Marketing Council (NAMC) of South Africa commissioned a study to understand the table grape export market to Europe. This study highlighted various issues that the South African industry needed to address if it was to remain a competitive global supplier (PROMAR, 2001: 285). These are listed below.

- The South African industry has been overly preoccupied with its own internal problems rather than developing mid- to long-term relationships with its customer bases in the international markets.

- Development and research, previously considered one of the great strengths of the South African industry, has to a certain extent been ignored, allowing its fledgling competitors to make great strides in the areas of quality and supply.

\subsection{Conclusions}

At present, the industry is largely dependent on European markets, and this high dependency has shaped the South African production patterns to suit the needs of traditional markets. The current cultivar profile does not fully meet the requirements of Eastern markets, which is to produce cultivars that have a large berry size and a long shelf life. This is straining export growth to Eastern markets, as producers lack cultivars with the characteristics desired by these markets. The industry has to ensure that the production of table grapes is quality-driven and that only popular cultivars of top quality are exported to international markets. 


\section{CHAPTER 6}

\section{DESCRIPTION OF THE SELECTED MARKETS}

\subsection{Introduction}

This chapter aims to discuss the current situation pertaining to selected markets (i.e. EU, China and India). In Chapter 1, it was shown that China and India present large trade opportunities when measured in terms of economic growth and the size of their consumer markets. These two countries have experienced large retail growth and infrastructure improvement in the last six years. Their seasons for table grape production and export are counter-seasonal to South Africa. In 2007, South Africa and China signed a table grape protocol promoting the export of table grapes from South Africa to China. South Africa also has active market access to India. These facts have motivated the selection of these two Eastern markets for this study.

This chapter discusses how Chinese and Indian markets differ from the traditional South African export market (i.e. the EU), and how these differences will affect South African export structures. The three markets are evaluated based on consumption trends, retail growth, consumer spending ability, infrastructure development and product price growth. The chapter then provides an analysis of how relevant trends or events will unfold in the future.

\subsection{Description of the European market}

Most of South African table grapes are exported to Europe. The table grape producers have enjoyed premium returns on this market over many decades, and European importers have expressed their satisfaction regarding the quality of products supplied by South Africa. It appears that exporters have been in a comfort zone concerning their exports to Europe, which has caused them to focus less on finding alternative markets. The increase of exports from Chile, Argentina, Peru, Namibia and Brazil since the early 2000s has challenged the dominance of South African products in Europe. The boom of export volumes from southern hemisphere countries has given northern hemisphere importers much freedom to choose products from different countries and has also triggered northern hemisphere markets to implement strict technical and environmental barriers (also known as green impediments) to protect the wellbeing of consumers. 


\subsubsection{European population and economic growth}

The average population growth for the EU-15 was $0.3 \%$ between 2000 and 2003. This percentage fell to $0.2 \%$ between 2003 and 2007 (UN, 2008). The table below indicates that EU15 population growth has remained constant over the last five years and is projected to remain the same at least until the year 2012. The projected stagnation of EU-15 population growth is based primarily on the persistence of extremely low fertility rates and a high migration rate. The fertility rate has fallen to below the level required for the reproduction of the population (two children) in most EU-15 countries. One implication of the low fertility rate is that the population of EU-15 is aging rapidly. In the year 2000, the median age of some EU-15 countries was about 40.

This rapidly aging population of many EU-15 countries means that their dependency ratios (the ratio of economically inactive to economically active persons) will rise in the coming years. This will have a negative impact on grape consumption over the longer term, as grapes are perceived as luxury and expensive fruits. As the dependency ratio increases, household incomes will decline and consumers will resort to more defensive spending (buy cheaper products). This is evident when one looks at the current spending patterns in Europe under the recession conditions that took place in mid-2008. The consumers have adopted a defensive spending approach resulting in lower purchasing power.

Table 5: EU-15 Macroeconomic indicators:

\begin{tabular}{|l|l|l|l|l|l|l|l|l|l|l|}
\hline & Unit & Country & $\mathbf{2 0 0 5}$ & $\mathbf{2 0 0 6}$ & $\mathbf{2 0 0 7}$ & $\mathbf{2 0 0 8}$ & $\mathbf{2 0 0 9}$ & $\mathbf{2 0 1 0}$ & $\mathbf{2 0 1 1}$ & $\mathbf{2 0 1 2}$ \\
\hline $\begin{array}{l}\text { Population } \\
\text { Growth }\end{array}$ & Million & EU-15 & 384 & 386 & 387 & 387 & 388 & 388 & 389 & 389 \\
\hline $\begin{array}{l}\text { Real GDP } \\
\text { Growth }\end{array}$ & $\%$ & EU-15 & 2.52 & 2.72 & 2.14 & 1.76 & 1.93 & 2.06 & 1.95 & 1.98 \\
\hline $\begin{array}{l}\text { Consumer } \\
\text { Price Index }\end{array}$ & $\%$ & EU-15 & 1.96 & 2.01 & 2.45 & 4.03 & 3.08 & 2.04 & 2.2 & 2.0 \\
\hline
\end{tabular}

Source: Global Insight, 2008 


\subsubsection{Production and consumption in Europe}

Europe is the second-largest producer, importer and consumer of table grapes in the world. On average, between 2000 and 2006, Europe produced 3.5 million tons (second after China), imported 3.9 million tons (second after the US) and consumed 2.2 million tons (second after China) (Eurostats, 2007). Globally, China is the world's largest producer and consumer of table grapes. As shown in Table 4, below, Italy is the EU's foremost consumer of table grapes, consuming twice the amount of Germany (the second-largest consumer in Europe). Other leading table grape-consuming nations include the UK, a major importer of table grapes (importing substantial quantities from South Africa), Spain and Greece (second and third major producers of table grapes in Europe).

Table 6: Table grape consumption in Europe

\begin{tabular}{|c|c|c|c|}
\hline Average co & & & \\
\hline Country & $(1000$ tons $)$ & Country & $(1000$ tons $)$ \\
\hline Italy & 750.50 & Sweden & 42.90 \\
\hline Germany & 315.83 & Czech Rep. & 39.00 \\
\hline UK & 300.77 & Bulgaria & 38.60 \\
\hline France & 220.49 & Ireland & 34.20 \\
\hline Spain & 154.30 & Finland & 33.30 \\
\hline Greece & 145.68 & Hungary & 32.33 \\
\hline Poland & 129.67 & Austria & 29.82 \\
\hline Portugal & 71.40 & Lithuania & 17.15 \\
\hline Belgium & 65.80 & Finland & 11.19 \\
\hline Romania & 64.00 & Estonia & 9.43 \\
\hline Netherlands & 45.83 & Malta & 4.62 \\
\hline
\end{tabular}

Source: Eurostat, 2007 
The EU is the largest importer of fresh fruits and vegetables in the world. With EU production limited by the relatively cooler climate and shorter growing seasons, the population is dependent on imports of fruits originating predominantly from countries in the southern hemisphere, where production is counter-seasonal to the EU.

Understandably, the large importing countries are also the large consuming nations. This is except for the Netherlands, where the focus is primarily on the table grape trade, not on consumption. Almost $70 \%$ of imported products in the Netherlands are transhipped to other European countries and are not consumed in the Netherlands. Germany's imports have decreased by $10 \%$ over the past six years. This is in contrast to other EU countries, specifically the UK, the Netherlands and the Czech Republic, all with growth rates of almost 50\%. Italy, as the EU's leading consumer and producer of table grapes (responsible for more than half of the region's total production), has no significant import market (USDA, 2007: 13).

Table 7: Imports of table grapes by EU-25 (Tons)

\begin{tabular}{|l||l||l|l|l||l|l|l|l|}
\hline $\begin{array}{l}\text { Exporting } \\
\text { country }\end{array}$ & $\mathbf{2 0 0 1}$ & $\mathbf{2 0 0 2}$ & $\mathbf{2 0 0 3}$ & $\mathbf{2 0 0 4}$ & $\mathbf{2 0 0 5}$ & $\mathbf{2 0 0 6}$ & $\mathbf{2 0 0 7}$ & $\mathbf{2 0 0 8}$ \\
\hline South Africa & 161837 & 177496 & 188757 & 213991 & 191421 & 196724 & 194035 & 192264 \\
\hline Chile & 80121 & 86188 & 110918 & 119676 & 154275 & 177955 & 171905 & 175342 \\
\hline Argentina & 20186 & 24701 & 26161 & 32473 & 36331 & 37556 & 42101 & 39996 \\
\hline Brazil & 14585 & 22089 & 33179 & 22017 & 41116 & 43397 & 49507 & 50992 \\
\hline Egypt & 5184 & 9320 & 9547 & 17217 & 24287 & 31494 & 38479 & 40018 \\
\hline Israel & 6441 & 4952 & 2963 & 7586 & 7823 & 6753 & 5626 & 5513 \\
\hline Pamibia & 1949 & 4959 & 6476 & 6070 & 1256 & 15066 & 11764 & 11529 \\
\hline
\end{tabular}

Source: Eurostat, 2008 and SHAFFE, 2009 


\subsubsection{Market barriers and challenges in the European markets}

In this section, the main challenges faced by South African exporters in this market are discussed.

\section{(i) Market competition}

South Africa is the largest supplier of table grapes to Europe, followed by Chile, Argentina and Brazil. These countries have shown large export growth in the past five years, exerting pressure on the South African export price. The export volumes from Chile and South Africa, the largest and second-largest exporters of table grapes in the southern hemisphere, increased respectively by $4 \%$ and $6 \%$ per annum between 2000 and 2007. Exports by Peru, New Zealand, Namibia and Brazil increased, on average, by 35\%, 33\%, 30\% and 24\% respectively over the same period (BFAP, 2008: 3). BFAP projected that there would be an additional 68 million cartons in the export market by 2012, which would have a significant impact on the market price. Between 2000 and 2007, the average price received for South African grape exports declined by 8\% year on year (BFAP, 2008: 4). It is projected that competition in Europe will continue to rise, making the market less profitable for South African exporters.

\section{(ii) Export standards and compliance costs}

The term 'market barrier' refers to all factors that restrain free and fair trade. Over the last decades, nations have reduced their tariff barriers as agreed under the auspices of the World Trade Organisation (WTO). But the reduction of export duties on its own does not necessarily mean that international trade has been liberalised. Over the last decade, one has seen the rise of a wide range of export standards being implemented to protect domestic producers from foreign exporters by limiting the import volumes. The costs of complying with export standards are relatively high making it difficult for emerging grower to export.

Technical and environmental export standards (e.g. Phytosanitary and sanitary requirements): Importers demand strict adherence to prescribed production practices that need to be implemented by producers cultivating for an export market. Retail chains have developed a series of these environmentally sustainable production standards as formal codes of practice for the growers to practice (e.g. global-GAP, Natures Choice, SEDEX and IP Pack house). South African table grape producers are required to produce phytosanitary and sanitary certificates as well as food safety and traceability certificates when exporting to European countries. In recent 
years, European supermarkets have demanded that foreign producers indicate the carbon footprint of the produce they are supplying to the market.

The population's high incomes drive environmental consciousness as the force behind the tight environmental health standards, limiting market access in Europe. The relation between higher incomes and environmental consciousness can be explained using an inverted U-shaped curve (see Figure 13, below), also known as the Environmental Kuznets Curve (EKC) (Cole, 1999: 86 and Stern, 2003: 1). The proposition of the curve states that early stages of economic development see a positive relationship between economic growth and environmental degradation, but once a certain level of development is attained, further economic growth actually serves to benefit the environment (Kuznets, 1955 and Cole, 1999: 86). The current European market situation proves the Kuznets theory right. European economic growth has reached a point where environmental degradation is restrained. The number of environmental regulations has increased, making it difficult to export to Europe. For example, the permitted chemical residue (MRL's standards) has declined significantly in the last ten years. The reasons for increasing the number of environmental regulations are: (i) environmental concerns become a higher priority after society has maximised investments in health and education; (ii) high-income societies have large personal budgets for monitoring enforcements; (iii) high levels of income and education empower markets to enforce higher environmental standards.

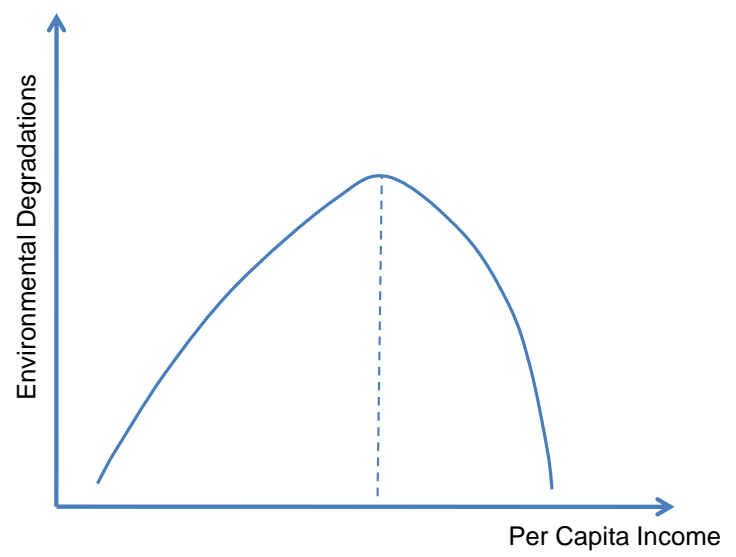

Figure 13: An inverted U-shaped relationship between environmental degradation and per capita income: Kuznets Curve

Source: Cole, 1999: 91 
Logistical barriers: These barriers include quality of distribution channels, mobility of persons and goods from ports to wholesalers/supermarkets, high-quality infrastructure (roads, railways, waterways, ports, airports, intermodal freight terminals and product pipelines) and use of modern transport (refrigerated trucks to transport perishable fruits and vegetables). It appears that European countries have effective infrastructural systems that allow rapid and easy mobility of persons and goods. The WEF report (2008) supports the fact that European countries have highly developed infrastructures; for example, Germany is ranked number one in the world (country with the most efficient and highest quality infrastructure, which is critical for ensuring the efficient functioning of the economy), France is ranked number two, Switzerland number four, the Netherlands number eleven and the UK number 13 in the world rankings. These highly developed logistics networks facilitate the rapid mobility of table grapes within the markets, thus maintaining the quality of the products at a high level.

\subsubsection{EU as trade partner to South Africa}

This section discusses the current table grape trading relationship between South Africa and Europe.

\subsubsection{Significance of EU markets to $\mathrm{SA}$ producers}

South Africa is Europe's oldest and most reliable supplier of table grapes. European consumers prefer the high quality and sweet, juicy taste of grapes from South Africa. Table 6, below, indicates that Europe is the dominant destination for South African exports. As mentioned earlier, the high dependency on European markets is mainly the results of political history (i.e. South Africa was colonised by Europeans, and together, they have established a good trading partnership governed by the TDCA), and the secondary factor is the lack of understanding of emerging markets by South African exporters and producers. 
Table 8: South African table grape exports to Europe (tons): 2002-2009

\begin{tabular}{|l|c|c|c|c|c|c|c|}
\hline $\begin{array}{l}\text { Market } \\
\text { Classification }\end{array}$ & $\begin{array}{c}\mathbf{2 0 0 8 / 2 0 0} \\
\mathbf{9}\end{array}$ & $\begin{array}{c}\mathbf{2 0 0 7 / 2 0 0} \\
\mathbf{8}\end{array}$ & $\begin{array}{c}\mathbf{2 0 0 6 / 2 0 0} \\
\mathbf{7}\end{array}$ & $\begin{array}{c}\mathbf{2 0 0 5 / 2 0 0} \\
\mathbf{6}\end{array}$ & $\begin{array}{c}\mathbf{2 0 0 4 / 2 0 0} \\
\mathbf{5}\end{array}$ & $\begin{array}{c}\mathbf{2 0 0 3 / 2 0 0} \\
\mathbf{4}\end{array}$ & $\begin{array}{c}\mathbf{2 0 0 2 / 2 0 0} \\
\mathbf{3}\end{array}$ \\
\hline Continental EU & 140162 & 138289 & 135299 & 138928 & 139643 & 165773 & 135848 \\
\hline UK & 46691 & 54356 & 58737 & 57795 & 51778 & 48218 & 52908 \\
\hline Total EU & $\mathbf{1 8 6 ~ 8 5 3}$ & $\mathbf{1 9 2 6 4 5}$ & $\mathbf{1 9 4 0 3 6}$ & $\mathbf{1 9 6 7 2 3}$ & $\mathbf{1 9 1 4 2 1}$ & $\mathbf{2 1 3 9 9 1}$ & $\mathbf{1 8 8} 756$ \\
\hline $\begin{array}{l}\text { \% of total SA } \\
\text { export }\end{array}$ & $\mathbf{8 6 \%}$ & $\mathbf{8 6 \%}$ & $\mathbf{8 5 \%}$ & $\mathbf{8 5 \%}$ & $\mathbf{9 0 \%}$ & $\mathbf{8 8 \%}$ & $\mathbf{8 9 \%}$ \\
\hline
\end{tabular}

Source: PPECB and SATI, 2009

From Table 8 above it is evident that only 3\% of South African exports has been relocated from EU to other global markets in the last eight years. This shows that South African exporters are at the comfort zone in Europe and they lacking the willingness to diversify their export markets.

\subsubsection{Intervention needed to improve competitiveness in Europe}

In the past eight years, South Africa's competitive advantage in Europe has been declining due to the emergence of quality export quantities from alternate southern hemisphere countries. There is a great need for South Africa to regain its market share by stimulating its product awareness through generic promotions and product differentiation. The promotions that are of a generic nature will boost the country's image as a preferred supplier of quality grapes. In-store promotions and media publications that aim at providing consumers with product nutritional information have proved to be a suitable platform to regain market competitive advantage. In 2008, the South African Plum Association (a division of Deciduous Fruit Producers Trust (DFPT)) conducted a plums promotion in Europe to promote South African plums. The promotional campaign was a success, as South African plum sales increased by $14 \%$ and the movement of South African plums on the store shelves was much faster compared to previous years (DFPT, 2008: 2). The table grape industry needs to support South African producers by conducting table grape promotional campaigns in major European supermarkets during peak harvest times in December and January, when all South African regions are harvesting (SATI, 2008 and DFPT, 2008: 11).

The European markets have become more difficult and costly to supply. This has meant that South African producers need to focus on developing innovative products in order to retain their global market share. One of the innovations currently being tested in selling is the packing of 
two or three different cultivars in a single punnet/box, which offers more value to customers (SATI, 2008: 5).

\subsection{Description of the Chinese market}

China is known to be a traditional market for Australia and this is evident when looking at the strength of the existing trade agreement between these two countries (BOABC, 2009). Although Australia is not a major player in the global table grape industry, they export substantial amounts of other agricultural products to this market. The factor that promotes Australian exports to China is the shipping distance (geographical allocation) between the two countries. Australia is geographically closer than Chile, Peru, Argentina and South Africa to Far East markets (USDA, 2007: 13).

In recent years, Chilean exports to China (direct route to China, not via Hong Kong) have increased significantly. Chilean exports to China have increased from 3000 cartons $(4.5 \mathrm{~kg}) \mathrm{in}$ 2003/4 to 1.5 million cartons in the 2007/8 season (Decofruit, 2009).

\subsubsection{Overview of the Chinese market}

The Chinese table grape industry has grown substantially in the last five years when measured in terms of both production growth and import growth. The total grape production forecast for the 2008 season indicates an increase of $10 \%$ to nearly 7 million tons over the next two seasons, and table grapes represent about $80 \%$ of this quantity (BOABC, 2009 and USDA, 2008: 3). The most planted table grape variety in China is the Red Globe, which is still growing rapidly in terms of hectares planted. The popularity of Red Globe comes from the characteristics of this cultivar (i.e. large berry size, allowing consumers to peel berries easily; long shelf life; cultivar colour and good eating character).

The Chinese table grape industry is still focused on quantity rather than quality (USDA, 2008: 3). The contributing factors to this approach are the lack of development of post-harvest technologies and underdeveloped infrastructures, as well as lack of new production techniques. Table 9, below, indicates the growth in production, consumption and imports over the last three seasons. The rising consumption trend indicates a growing demand for table grapes in China, 
stimulated by changing lifestyles and rising household incomes. The area planted with table grapes increased from 408 thousand hectares in the 2005/6 season to 443 thousand hectares in the $2007 / 8$ season.

Table 9: Chinese table grape production, consumption and imports

\begin{tabular}{|l|l|l|l|l|l|l|l|}
\hline \multicolumn{2}{|l|}{ China: production, consumption and imports of table grapes (000 Tons) } \\
\hline Year & $\begin{array}{l}\text { Area } \\
\text { Planted }\end{array}$ & Production & Imports & $\begin{array}{l}\text { Fresh Dom. } \\
\text { Consumption }\end{array}$ & $\begin{array}{l}\text { Exports, } \\
\text { Fresh }\end{array}$ & $\begin{array}{l}\text { For } \\
\text { Processing }\end{array}$ & $\begin{array}{l}\text { Total } \\
\text { Distribution }\end{array}$ \\
\hline 2006 & 408 & 5794 & 53 & 4076 & 21 & 1750 & 5848 \\
\hline 2007 & 419 & 6271 & 44 & 4354 & 36 & 1925 & 6315 \\
\hline 2008 & 443 & 6900 & 40 & 4838 & 52 & 2050 & 6940 \\
\hline
\end{tabular}

Source: BOABC, 2009 and USDA, 2008

As the country's economy develops, fruit consumption also increases, portraying market potential for exporting countries. The consumption of fruits and vegetables is growing, parallel with an increasing population and economic growth. Table grape consumption is much higher in the southern part of China where high-income consumers are located. The southern region of China is considered to be an industrial area with a much-improved infrastructure, systems and modern retail sectors (BOABC, 2009).

\subsubsection{Competition and consumer preferences}

The demand for imported fruits is increasing, as is indicated by growing amounts of fresh fruit coming into China directly, and indirectly to south China via Hong Kong (the grey channel). The majority of Chinese consumers prefer US fruit and food products (Research Surveys, 2006: 16). This is particularly true in Southeast China (the Guangdong and Fujian provinces), which is the ancestral homeland of two-thirds of Americans of Chinese descent (Encyclopedia.com, 2008). However, some fruits are frequently mislabelled as US-grown, as retailers attempt to capitalise on the higher prices they might earn from US-branded fruits. The consumption of domestic and imported fresh fruit will continue to climb, paralleling rising consumer incomes (Research Surveys, 2006: 25). The strong demand for fruit in China is also reflected by the strong growth in production that took place between the early 1990s and 2000s; growth in 
production of about $300 \%$ was observed in that country, and almost all of it was consumed within the country. US apple exports to China between 1993 and 2000 increased by 55\% and US grape exports increased by $380 \%$, making the US a major supplier of fruits to China and Hong Kong (Encyclopedia.com, 2008). Fruit is a particularly popular gift item and is commonly served at up-market restaurants. Only middle-income and higher-income consumers are known to frequently purchase imported fruit, which can cost two to five times more than domestic alternatives. A recent study indicate that $38 \%$ of Chinese consumers eat table grapes on a regular basis (two or more times per week) (Research Surveys, 2006: 16).

Research Surveys (2006) find that apples (Red Delicious), table grapes (Red Globe) and navel oranges remain the three big fruit imports to South China, but other fruits also enjoy market niches. Quantities of Thompson Seedless, Crimson Seedless, plums, kiwifruits, lemons, nectarines and cherries are seasonally available in South China's urban markets and other markets in the Eastern and Northern regions of China. The demand for Crimson Seedless is also showing fast growth in the Chinese market. The rising popularity of Crimson Seedless comes from the colour development and good eating character of this cultivar (i.e. crunchiness) (Research Surveys, 2006: 25).

The findings of Research Surveys (2006) further show that the Chilean and South African Red Globe grapes are seen in the market largely when California grapes are out of season. Chilean and Peruvian grapes are the largest competitors to South African grapes in this market. Both these countries' grape exports get government support (in the form of promotional activities) that subsidises their promotions, giving them a competitive advantage when compared to South Africa (Research Surveys, 2006: 28). In general, the fruit trade in China is booming, most of the fruit, including imports, is sold at open-air wholesale markets (wet markets) and in traditional retail markets. However, substantial quantities of fruit are beginning to appear in up-market supermarkets, and these new supermarkets are emerging in cities such as Guangzhou, Shanghai and Shenzhen (Research Surveys, 2006: 31). While most imported fresh fruit is consumed in South China, some is shipped to North China, as fruit consumption is becoming increasingly significant in the Northern and Eastern parts of China (Research Surveys, 2006: 31). 


\subsubsection{Distribution channels and logistical constraints}

Logistical constraints such as poor port facilities, causing port congestion during the peak season, and underdeveloped infrastructures and transport systems remain major concerns in many Asian countries (Research Surveys, 2006: 48 and Promar, 2008: 3). Research Surveys (2006) and Promar (2008) found that the internal distribution of grapes is hampered by an overburdened rail network, a poor highway road system and a lack of refrigerated truck transport. Using refrigerated truck transport from Guangzhou to Shanghai, a distance of about $1207 \mathrm{~km}$, can take approximately three days, indicating high road traffic. The cold storage capacity and handling technologies remain poor, but are improving. The controlled-atmosphere storage facilities are not well developed yet, but such facilities are improving in the fruit producing areas of North China, presenting large trade opportunities across all the provinces of China (USDA, 2008: 5 and Research Surveys, 2006: 51).

\subsubsection{Market barriers in the Chinese market}

Food safety issues and the spread of retail outlets are the strong drivers of market growth in our modern day. Both consumers and importers are starting to position themselves at high-value markets and are becoming more conscious about food-safety issues. At present, China has imposed a protocol on South Africans intending to export to that country via the legal route. The protocol appears to be a major non-tariff barrier for South African exporters, as their products have to be exposed to a minimum sterilising period of 23 days before they reach the markets. This steri-period has a negative impact on the quality of table grapes, as the days spent in quarantine result in poor product quality.

Internal market forces appear to have a major effect on the trade environment in China. The study conducted by Research Surveys in 2006 indicated that tariff duties were not the primary barrier in China, but internal market forces, such as psychological barriers, logistical constraints and product awareness, remained the largest impediment in the market. The psychological issues such as trust and commitment play a significant role in trade relationships. The trade relationship with Chinese importers is largely influenced by the level of trust developed between exporter and importer. Chinese importers are conservative and they still believe in making sound trade deals through face-to-face communication rather than through modern communication 
technologies such as telephones or emails (Research Surveys, 2006: 78).Generic promotions also seem to play a critical role in improving product awareness. South African table grape exporters have indicated that conducting in-store promotions in China can benefit the sector, as this will increase product awareness and stimulate the rapid movement of South African products on the shelves.

Research Surveys (2006) and later supported by Promar (2008) argue that the Chinese market, like other Far East markets, is a large consumer of seedless varieties. Red Globe (exceptional due to cultivar characteristics), Crimson Seedless and White Seedless varieties are the favourites in the Chinese market because of their colour and eating character. There are four factors that play significant roles during the purchasing process of table grapes: (i) cultivar type; (ii) brix level (sweetness); (iii) bunch size and firmness and (iv) colour development and product appearance. Chinese consumers prefer seedless varieties that have firm bunches and large berry sizes. They tend to prefer varieties that have high levels of sweetness and well-developed colour. Consumers also perceive reserved bloom on berries as an indication of high quality and freshness. Cultivars with shattering problems, browning, looseness of bunch and uneven berry development are less profitable in the Chinese market.

\subsubsection{China as a trade partner to South Africa}

\subsubsection{Significance of Chinese market to South African producers}

The table grape trade between China and South Africa is modern, as South Africa only obtained market access status to China in 2006. However, substantial amounts of grapes have been exported to China via Hong Kong (over the past five years, about 1 million cartons of grapes were exported to Hong Kong every season, and a large percentage of these were transhipped to China). In 2008, the first year of direct export to China, South Africa exported a total of 30 thousand cartons directly, and 1.1 million cartons indirectly via Hong Kong (SATI, 2009). China on its own has the potential to absorb all South African exports every season (Research Survey, 2006: 90). 


\subsubsection{How China differs from the EU market}

The Chinese market, like other Far East markets, is economically, psychologically, environmentally and socially different from the traditional export markets, and therefore, gaining an improved understanding of these differences will be a key tool to enhancing the producers' capacity to supply these markets successfully. The financial status of Chinese consumers is growing when measured by income levels and urbanisation rates. The Chinese have large family sizes compared to European families. This means that Chinese consumers buy table grapes in large containers compared with European consumers, who have shifted their preference from large $4.5 \mathrm{~kg}$ cartons to smaller $2.5 \mathrm{~kg}$ cartons or even $500 \mathrm{~g}$ punnets.

The Chinese attach high value to red grapes compared with European consumers who mainly prefer white grapes. They also tend to prefer certain shades of red, for instance grapes that appear pinkish (known as monkey-ass pink) compared with the dark-red grapes mainly consumed in Europe. This means that South African producers will need to adjust their production tactics to obtain the required colour type. The cultivation of table grapes with the required colour type for China and other Far East markets includes proper vine and bunch manipulation during the production process. The canopy management includes leaf and shoot removal, bunch suckering and tipping. This would have a significant impact on production costs, as it would elevate the costs of labour. It is important to mention that, besides red grapes, China is also a good market for black and white grapes.

In the previous sections, it was shown that technical barriers such as stringent MRLs and SPS standards as well as tight traceability regulations protect European markets. In contrast, China and other Far East markets are largely protected by psychological factors (i.e. level of trust between importer and exporter), tariff barriers and protocols. The sanitary requirements are not required for South Africa grapes exported to China, provided that they are kept at a sterilisation temperature of $-0.5^{\circ} \mathrm{C}$. This means China is less protected by technical and environmental barriers than Europe.

The most important difference between European and Chinese markets is the price mechanism used when trading. The European markets use a Minimum Guaranteed Price (MGP) when procuring table grapes, while China uses a Fixed Price Mechanism (FPM). This means that when South African exporters sell their grapes to China, they have a guaranteed price, while European prices are not guaranteed and exporters can receive a price that is lower than the initially 
expected price used for budgeting. The MGP guarantees only a minimum percentage of the whole price, and the rest is determined by the condition of the product when it arrives at the markets.

The shipping costs and overseas handling costs are different when comparing the EU and China. It has been reported by table grape exporters that it costs $37 \%$ less to sea freight table grapes from South African ports (e.g. Cape Town) to China (e.g. Shanghai), as opposed to Europe (e.g. Rotterdam). The selling of table grapes in China is also different from selling in Europe. In China, the bulk of the fruit is sold on wholesale and open-air markets (i.e. even directly from containers, and not from formal retail stores), while in Europe, grapes are sold to formal retailers such as TESCO and ASDA.

\subsection{Description of the India market}

India is one of the fastest growing food markets in the world. It is a big fruit producer in its own right, but imports of fresh fruit have been increasing significantly in the last five years (Promar International, 2008: 4). The Indian consumer market at both retail and foodservice level is rapidly evolving. Imports of many fresh and processed agri-food products have often been hampered by the attitude of the Indian government towards the reduction of both tariff and nontariff barriers; these have been kept at a relatively high level compared with global standards (Promar international, 2008: 9). The importing of grapes at present is relatively modest, but if South Africa expands its exports to India, it would be a counter-seasonal supplier to that market.

\subsubsection{Overview of the Indian horticultural sector}

In the world horticultural sector, India is one of the largest producers of fruits (46 million tons), with a global share of over $10 \%$, and is the second largest producer of vegetables (80 million tons), with a global share of over 15\% in 2007 (Apeda.com, 2008). In spite of this massive production, about $30 \%$ to $35 \%$ of the produce is lost annually due to a lack of proper infrastructure and inadequate use of modern post-harvest technologies (Apeda.com, 2008).

The Indian table grape sector has shown some growth over the last few years. The area planted with table grapes has increased from 45.5 thousand hectares in 2001 to 64.3 thousand hectares in 2006, representing a $41.3 \%$ increase in area planted under table grapes. The areas planted with 
table grapes are expected to increase as the Indian government invests heavily in agriculture to improve agricultural practices and productivity (Apeda.com, 2008 and Promar International, 2008: 9). Table 10 below represents the hectares planted with table grapes and production from the early 2000s until 2006. Almost all Indian table grapes are produced in three areas (Maharashtra, Karnataka and Tamil Nadu). More than 95\% of Indian production comes from these three areas, with Maharashtra producing $78 \%$ of the total Indian production. Other areas that produce table grapes on a small scale are Andhra Pradesh, Punjab and Haryana (Apeda.com, 2008 and UN Comtrade, 2007).

Table 10: Indian table grapes: area planted and production

\begin{tabular}{|l|l|l|}
\hline YEAR & Area (000 HA) & Production (000 Tons) \\
\hline 2002 & 47.5 & 184.2 \\
\hline 2003 & 52.1 & 1247.8 \\
\hline 2004 & 57.8 & 1474.8 \\
\hline 2005 & 60.5 & 1564.7 \\
\hline 2006 & 64.3 & 1630.7 \\
\hline 2007 & 66.9 & 1668.2 \\
\hline 2008 & 70.5 & 1741.5 \\
\hline
\end{tabular}

Source: Apeda.com, 2008, Promar International, 2008 and UN Comtrade, 2007.

India is one of the important exporters of table grapes to the global markets, although Indian exports are still based on quantity rather than quality. The main destinations for Indian table grape exports are the Netherlands, the UK, the UAE, Bangladesh and Belgium. Indian table grape exports are expected to reach 30183 containers in 2009, compared to 2500 in 2007 (Apeda.com, 2008). In 2005 a traceability system was set up, which enables Indian exporters to trace and track each table grape carton/container back to farm level (Apeda.com, 2008). 


\subsubsection{Consumption and consumer preferences}

The Indian market at both the wholesale and retail level is rapidly developing and the main driver of this growth is fast growing middle class consumer numbers, approximately 200-300 million spread across the country (Rabobank, 2007: 20). Indian consumers spend 57\% of their income on food and groceries and another $8 \%$ on eating out in restaurants and fast food outlets (The SCS Group, 2007: 18). The rising income of Indian consumers means that consumers are willing to buy high-value and processed agri-food products. They are becoming more health conscious and moving towards packaged and brightly branded products. The demand for fruits and vegetables has increased significantly over the last years, stimulated by changing lifestyles and rising household incomes (Promar International, 2008).

The US is the major supplier of table grapes to this market. Chilean export volumes have increased from 25545 cartons (4.5kg) in the 2003/4 season to 77277 cartons in the 2007/8 season, a 202\% increased over four seasons (Decofruit, 2008). Local production remains a major competitor to exporting countries in the months from April to July. Local producers receive government support in various ways, firstly through production subsidies and secondly through protection, as government implemented binding high-tariff and non-tariff barriers to protect local producers from foreign suppliers. This protectionism has hampered the growth of exports to Indian markets (Promar, 2008: 4).

In the long term, the Indian market is projected to become the largest importer of fruits after they have reduced their trade barriers (Rabobank, 2007: 21 and Ernst and young, 2008: 20). Economic and social changes will also stimulate the consumption of fresh produce in India. Rabobank (2007) note that the rural Indian consumer is economically, socially and psychologically different from his or her urban counterpart. Therefore, it is important that exporters understand the consumer characteristics of all market segments. Rabobank (2007) further note that three to five years back, Indian consumers would not have eaten fruits which were not available on certain seasons, nut today even in less developed cities, they expect all seasonal fruits to be available all year round (Rabobank, 2007: 23). The most important factors for the Indian market when it comes to buying fresh products are (i) the price of the product; (ii) the quality and freshness of the product; (iii) convenience and eating character; and (iv) branding and promotions of the product (Ernst and Young, 2008: 22 and Promar, 2008: 69) 


\subsubsection{Distribution channels and logistical constraints}

Infrastructural development, cold-supply chain management, retail development and retail distribution across the country have been the primary focus of the Indian government over the last couple of years (Rabobank, 2007: 34). In recent years, massive developments have been made to (i) improve transport systems to facilitate the mobility of products within the country; (ii) improve cold storage facilities and (iii) reduce port congestion problems. A Rabobank (2007) investigation into the status quo of the Asian fresh market showed that transport systems (road and rail transport) have improved significantly in the last two years. Rabobank found that in some Asian countries, particularly India and Thailand, the wet markets are developing into tourist attractions, showcasing how fresh produce was sold in the old days. The improved infrastructure has facilitated the movement of products from traditional wet markets to the formal retail sector.

The Indian retail sector, consisting of over 15 million outlets, is estimated to provide employment to over 18 million people. The sector has been growing at a steady rate of over 5\% per year and accounts for around 10\% of the country's GDP (PricewaterCoopers, 2007: 67). The retail sector in India is highly fragmented and dominated by small, individually owned businesses. The organised retail sector is estimated to account for $5 \%$ of the overall market, but this percentage is anticipated to grow exponentially in the next ten years. The growth of the formal retail sector is driven by increasing incomes, growing exposure to overseas markets, availability of credit cards, increased life-style spending and higher consumer mobility. The key players in the formal retail sector are Shoppers Stop, Pantaloon, RPG Group and DS Group (PricewaterCoopers, 2007: 68 and Promar International, 2008: 15).

\subsubsection{Other market barriers}

Tariff barriers remain the biggest barrier in the Indian market. The market is protected by high binding tariff duties that limit import growth. The WEF report (2008) shows that this market has high tariff duties in place, which hampers the freedom to trade freely.

Indian consumers are becoming more health conscious and more concerned about food safety issues. Currently, there are more than twenty Indian laws and regulations relating to food safety 
issues, some overlapping with others. A number of different Indian ministries and departments administer these laws and regulations (Apeda.com, 2008 and Promar International, 2008: 42). Many of the laws were drafted soon after independence, in conditions different from today, when India was in the early stages of ensuring food self sufficiency, and the food industry was in an emerging stage and faced with different challenges.

The focus of these food laws is aimed at one or more of the following: to (a) prevent food adulteration; (b) regulate hygienic conditions of processing/manufacturing; (c) protect domestic agriculture and livestock from pests and diseases; (d) inform consumers about the products they eat (such as vegetarian or non-vegetarian, price, etc.) and (e) provide product specifications. Most of the existing food laws are equally applicable to imported food and fresh products. Implementation of these food laws and regulations is constrained by lack of trained manpower and infrastructure to conduct testing samples (Apeda.com, 2008). The Government of India (GOI) is in the process of implementing the Food Safety Standards Act of 2006, a single statute relating to food, in place of the existing multiplicity of food laws, and establishing a single regulator to replace the existing multiplicity of regulators. These pending agricultural standards will influence the growth of exports to India in the near future (Apeda.com, 2008).

\subsubsection{India as trade partner for South Africa}

\subsubsection{Significance of Indian markets to SA producers}

India has a population size of 1.19 billion. The Indian urban population is projected to increase from $28 \%$ to $40 \%$ of the total population by 2020 , and incomes are simultaneously expected to grow in these segments (Global Insight, 2008 and UN, 2007). The Indian consumer's lifestyle and profile is also evolving rapidly (Promar International, 2008: 7). Young Indian consumers are adopting a Western style of living and eating. They are demanding more fresh and healthy food (e.g. fruits and vegetables) and fewer staple products.

India is the world's fourth-largest economy when measured in terms of GDP, and is expected to rank third by 2012, just behind the US and China (Global Insight, 2008). The country is on the brink of becoming an economic powerhouse, ready to unleash its largely untapped potential for those who are willing to take the right step forward (Ernst and Young, 2008: 10). Over the last few years, the retail sector has become one of the fastest growing sectors of the Indian economy. 
Organised retail is expected to grow to $12 \%$ of the Indian retail industry in the next five years (Rabobank, 2007: 36, and Ernst and Young, 2008: 11).

Going forward, Indian retail sectors are likely to see an increase in the adoption of Supply Chain Management (SCM) solutions to improve core business processes such as global sourcing, distribution, innovation and visibility in financial and inventory management (Ernst and Young, 2008: 13). While the opportunities in Indian retail are growing, South African exporters must be aware that the consumer culture, business practices and industry dynamics in India can differ substantially from what they are accustomed to in European markets. They must also consider the high binding tariff duties that are set by Indian government.

\subsubsection{How Indian markets differ from European markets}

India has similar characteristics to China, and they both differ from the traditional South African fresh fruit export market. The factors that influence consumers' decision to purchase fruits include price, appearance, size of berry, packaging material and taste. Indian consumers are price sensitive and purchase products in bulk to meet the demands of large family sizes. They differ from European consumers, who concentrate on product quality and are willing to pay higher prices for premium products.

Unlike Europe, the Indian market is highly protected by tariff duties, a measure put in place by government to protect local Indian producers. The high tariffs increase the export costs of South African products in India. The Indian market is less protected by stringent technical and environmental barriers when compared to many European countries. The pricing mechanisms of Indian importers are also different to European importers, as they trade table grapes based on Fixed Price Mechanism (FPM), which ensures exporters guaranteed returns.

\subsection{Conclusions}

Factors such as geographical location (i.e. shorter shipping distances to the EU), duty-free access to markets, and growing demand for seedless varieties, as well as sustained demand for seeded varieties in Eastern Europe will continue to favour South African exports to Europe. However, the viability and profitability of Europe as an export market will be affected by increasing competition from other southern hemisphere countries and expanding food safety and quality 
regulations in Europe. Product differentiation and transparent packaging materials will boost South Africa's competitive advantage in the highly competitive conditions in Europe.

The emerging Eastern markets are showing growing trade opportunities, driven by rapid retail growth, robust economic growth and high urbanisation rates. The Chinese market is growing rapidly and table grape consumption is increasing significantly. This market places high value on seedless varieties, particularly red cultivars. China is a price-sensitive market and prefers grape cultivars that have a large berry size and good eating character (i.e. crispy berries with high sugar levels and good colour development). This market presents considerable trade opportunities to South African exporters when measured in terms of consumer size, growing price strength and infrastructural developments.

India has a relatively young population when compared to many other countries in the world. Indian household incomes are expected to rise by almost three times during the next two decades. This will largely be fuelled by continuing growth of India's service sector, increased productivity of businesses and the general opening up of the Indian economy. India is projected to become the fifth-largest consumer market in the world by 2025 (Promar International, 2008: 6). India is an important market for seedless cultivars, but certain seeded cultivars such as Red Globe have good potential in this market. Table 11, below, provides a summary of the market drivers and market characteristics of all three selected markets. 
Table 11: Market drivers and characteristics of the EU, Chinese and Indian table grape markets

\begin{tabular}{|c|c|c|c|c|}
\hline Parameters & $\begin{array}{l}\text { Sub- } \\
\text { Parameters }\end{array}$ & $\mathbf{E U}$ & China & India \\
\hline $\begin{array}{l}\text { Market } \\
\text { overview }\end{array}$ & $\begin{array}{l}\text { Market } \\
\text { Drivers }\end{array}$ & $\begin{array}{l}\text { Shorter shipping time to EU markets is } \\
\text { one of the major factors that promotes } \\
\text { exports from SA. } \\
\text { The duty-free access to EU by SA } \\
\text { exporters is without doubt the biggest } \\
\text { attractor of SA exports. } \\
\text { Higher earnings and health consciousness } \\
\text { among consumers promote the } \\
\text { consumption of fresh fruit in the EU. } \\
\text { High income drives environmental } \\
\text { consciousness as the force behind } \\
\text { environmental health standards, limiting } \\
\text { market access. }\end{array}$ & $\begin{array}{l}\text { The developing economy and rising } \\
\text { household incomes present new trade } \\
\text { opportunities for SA exporters in China. } \\
\text { Globalisation (i.e. retail growth, trade } \\
\text { liberalisation, urbanisation, etc.) is a } \\
\text { major driver of development in China. } \\
\text { Developing consumers promotes } \\
\text { consumption of imported fruits. }\end{array}$ & $\begin{array}{l}\text { The developing economy and rising } \\
\text { household incomes present new trade } \\
\text { opportunities for SA exporters in } \\
\text { India. } \\
\text { Globalisation (i.e. retail growth, trade } \\
\text { liberalisation, urbanisation etc.) is a } \\
\text { major driver of development in India. } \\
\text { Developing consumers promotes } \\
\text { consumption of imported fruits. }\end{array}$ \\
\hline
\end{tabular}




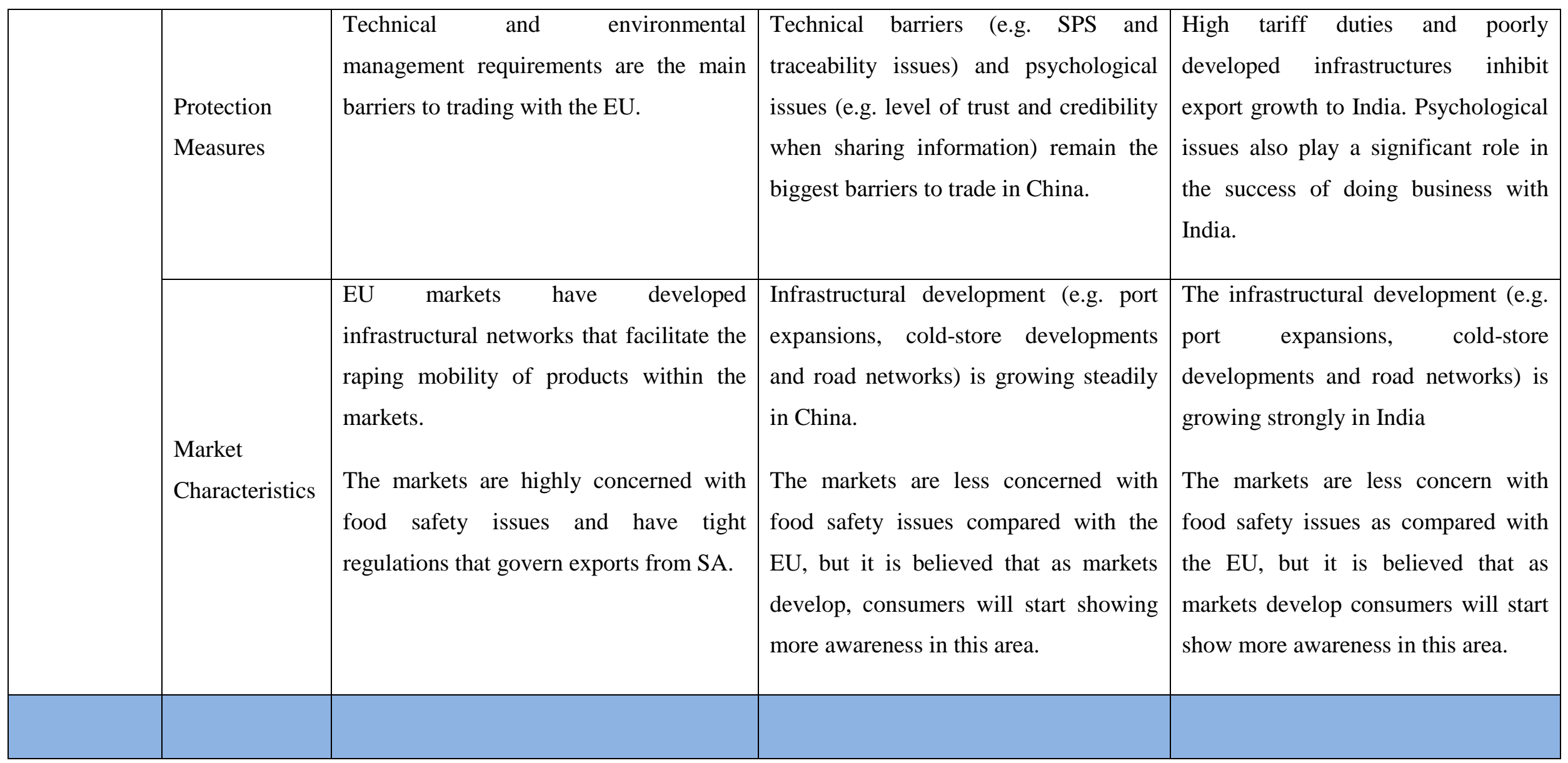




\begin{tabular}{|c|c|c|c|c|}
\hline $\begin{array}{l}\text { Marketing } \\
\text { Approach }\end{array}$ & $\begin{array}{l}\text { Marketing } \\
\text { Tactics or } \\
\text { Business } \\
\text { Model }\end{array}$ & $\begin{array}{l}\text { Reliability is the major factor that } \\
\text { determines success in EU markets. EU } \\
\text { importers want exporters who can deliver } \\
\text { products on time and who will assure } \\
\text { them premium quality. } \\
\text { White cultivars are popular in EU } \\
\text { markets, and their quality is measured by } \\
\text { their level of shininess (shiny grapes } \\
\text { represent high quality), absence of } \\
\text { foreign material and size of berries. The } \\
\text { demand for Red and Black cultivars is } \\
\text { also good in these markets. } \\
\text { Transparent packaging (punnets) is } \\
\text { gaining popularity with EU retailers, as it } \\
\text { allows consumers to select and evaluate } \\
\text { the product without handling it. This also } \\
\text { prolongs the shelf-life of the products. }\end{array}$ & $\begin{array}{l}\text { Level of trust developed with exporters } \\
\text { is crucial for the success in doing } \\
\text { business with China. Their business } \\
\text { approach is different from EU clients, as } \\
\text { they prefer to conduct business deals in } \\
\text { face-to-face meetings rather than } \\
\text { through using modern technology to } \\
\text { communicate. The Chinese are also } \\
\text { keen on doing business with } \\
\text { countries/partners who will share their } \\
\text { production technologies with them, so } \\
\text { that they can produce the same product } \\
\text { themselves in the future. } \\
\text { Red grapes are popular in this market } \\
\text { but there is a growing demand for black } \\
\text { and white grapes in the upscale market. }\end{array}$ & $\begin{array}{l}\text { Level of trust and reliability are the } \\
\text { key factors for success in India. They } \\
\text { are also keen to trade with partners } \\
\text { who are willing to share their } \\
\text { production technologies, so that they } \\
\text { can produce a similar product } \\
\text { themselves in the future. } \\
\text { Just like China, India also attaches } \\
\text { high value to red grapes because of } \\
\text { their colour and taste. }\end{array}$ \\
\hline
\end{tabular}




\begin{tabular}{|c|c|c|c|c|}
\hline & $\begin{array}{l}\text { Packaging } \\
\text { Material }\end{array}$ & $\begin{array}{l}\text { Transparent packaging materials are } \\
\text { preferred. } \\
\text { Product information (e.g. origin of } \\
\text { produce, product type and product size) } \\
\text { must be included on the packaging } \\
\text { material. }\end{array}$ & $\begin{array}{l}\text { Larger sized packaging materials are } \\
\text { preferred } \\
\text { Product information (e.g. origin of } \\
\text { produce, product type and product size) } \\
\text { must be included on the packaging } \\
\text { material. }\end{array}$ & $\begin{array}{l}\text { Larger sized packaging materials are } \\
\text { preferred } \\
\text { Product information (e.g. origin of } \\
\text { produce, product type and product } \\
\text { size) must be included on the } \\
\text { packaging material. }\end{array}$ \\
\hline & $\begin{array}{l}\text { Pricing } \\
\text { Mechanism }\end{array}$ & $\begin{array}{l}\text { MGP is used for procuring products from } \\
\text { South Africa. }\end{array}$ & $\begin{array}{l}\text { FPM is used for procuring table grapes } \\
\text { from South Africa. }\end{array}$ & $\begin{array}{l}\text { FPM is used for procuring table } \\
\text { grapes from South Africa. }\end{array}$ \\
\hline Export Chain & Shipping Costs & $\begin{array}{l}\text { Shipping time of up to six days. } \\
\text { Sea-freight cost per carton ( } 4.5 \mathrm{~kg} \text { ) to } \\
\text { ports such as Rotterdam (Netherlands) is } \\
\mathrm{R} 10.18 \text {, and to Tilbury (UK) is R10.42. }\end{array}$ & $\begin{array}{l}\text { Shipping time of } 23 \text { days under cold } \\
\text { sterilisation. } \\
\text { Sea-freight cost per carton ( } 4.5 \mathrm{~kg}) \text { to } \\
\text { port of Hong Kong, or Shanghai is } \\
\text { R6.53. }\end{array}$ & $\begin{array}{l}\text { Sea-freight cost per carton }(4.5 \mathrm{~kg}) \text { to } \\
\text { port of Nheva Sheva in India is } \\
\text { R6.62. }\end{array}$ \\
\hline
\end{tabular}




\begin{tabular}{|c|c|c|c|c|}
\hline & $\begin{array}{l}\text { Export } \\
\text { Compliance } \\
\text { (e.g. protocol, } \\
\text { SPS) }\end{array}$ & $\begin{array}{l}\text { Phytosanitary certificate required when } \\
\text { exporting table grapes to the EU. } \\
\text { Sanitary requirements include compliance } \\
\text { with traceability, food safety and MRL } \\
\text { additives. }\end{array}$ & $\begin{array}{l}\text { Phytosanitary requirements (e.g. } \\
\text { protocol). } \\
\text { No sanitary requirements. }\end{array}$ & $\begin{array}{l}\text { Phytosanitory requirements (e.g. } \\
\text { phyto-certificate). } \\
\text { No sanitary requirements. }\end{array}$ \\
\hline \multirow[b]{2}{*}{ Production } & Product Type & $\begin{array}{l}\text { Both seeded and seedless cultivars are } \\
\text { popular. }\end{array}$ & $\begin{array}{l}\text { Seedless cultivars are popular, but } \\
\text { certain seeded cultivars such as Red } \\
\text { Globe are also popular. }\end{array}$ & $\begin{array}{l}\text { Seedless cultivars are popular, but } \\
\text { certain seeded cultivars such as Red } \\
\text { Globe are also popular. }\end{array}$ \\
\hline & $\begin{array}{l}\text { Cultivar } \\
\text { choice } \\
\text { implications } \\
\text { for South } \\
\text { African } \\
\text { producers }\end{array}$ & $\begin{array}{l}\text { The current industry cultivar profile is } \\
\text { suitable for supplying European markets } \\
\text { therefore, producers need to maintain the } \\
\text { high-quality standards. }\end{array}$ & $\begin{array}{l}\text { Producers need to adjust their cultivar } \\
\text { compositions to meet the characteristics } \\
\text { of both Eastern and European markets. } \\
\text { This will affect the farms' cash flows as } \\
\text { producers uproot the less demanded } \\
\text { cultivars with new, popular cultivars. }\end{array}$ & $\begin{array}{l}\text { Producers need to adjust their cultivar } \\
\text { compositions to meet the } \\
\text { characteristics of both Eastern and } \\
\text { European markets. This will affect the } \\
\text { farms' cash flows as producers uproot } \\
\text { the less demanded cultivars with new, } \\
\text { popular cultivars. }\end{array}$ \\
\hline
\end{tabular}




\begin{tabular}{|c|c|c|c|}
\hline $\begin{array}{l}\text { Product } \\
\text { Character- } \\
\text { istics }\end{array}$ & $\begin{array}{l}\text { Quality is the main concern, followed by } \\
\text { taste. If consumers were dissatisfied with } \\
\text { product taste after the first purchase, it } \\
\text { will take them more than } 23 \text { days to } \\
\text { repurchase the same cultivar. Quality is } \\
\text { measured by large berry size, crispy } \\
\text { eating character, appearance and } \\
\text { shininess. }\end{array}$ & $\begin{array}{l}\text { Product price is the main determinant of } \\
\text { consumer purchasing decisions. Red } \\
\text { grapes are the favourites of consumers. } \\
\text { Level of bloom left on berries, size of } \\
\text { berries, absence of foreign material and } \\
\text { sweetness are the main determinants of } \\
\text { quality. }\end{array}$ & $\begin{array}{l}\text { Product price is the main determinant } \\
\text { of consumer purchasing decisions. } \\
\text { Red grapes are the favourites of } \\
\text { consumers. Level of bloom left on } \\
\text { berries, size of berries, absence of } \\
\text { foreign material and sweetness are the } \\
\text { main determinants of quality. }\end{array}$ \\
\hline $\begin{array}{l}\text { Environ- } \\
\text { mental } \\
\text { Requirements }\end{array}$ & $\begin{array}{l}\text { Environmental management (i.e. saving } \\
\text { the planet) is important to importers. } \\
\text { Carbon foot-print issues are also } \\
\text { increasing in the supermarkets. }\end{array}$ & $\begin{array}{l}\text { Environmental management concerns } \\
\text { are not a big issue yet. It is expected } \\
\text { that as formal retailers increase their } \\
\text { market shares, these will became an } \\
\text { important non-tariff barrier in these } \\
\text { markets. }\end{array}$ & $\begin{array}{l}\text { Environmental management concerns } \\
\text { are not a big issue yet. It is expected } \\
\text { that as formal retailers increase their } \\
\text { market share, this will become an } \\
\text { important non-tariff barrier in these } \\
\text { markets. }\end{array}$ \\
\hline $\begin{array}{l}\text { Socio- } \\
\text { economic } \\
\text { Requirements }\end{array}$ & $\begin{array}{l}\text { Socio-economic issues have drawn lot of } \\
\text { attention in supermarkets recently. This } \\
\text { includes 'ethical trade', which entails } \\
\text { evaluating the living conditions of farm } \\
\text { workers. Ethical trade is seen by } \\
\text { producers as another non-tariff barrier in } \\
\text { European markets. }\end{array}$ & $\begin{array}{l}\text { Socio-economic issues are not yet a } \\
\text { major concern but are expected to } \\
\text { become so as international retailers } \\
\text { increase their market shares in China. }\end{array}$ & $\begin{array}{l}\text { Socio-economic issues are not yet a } \\
\text { major concern but are expected to } \\
\text { become so as international retailers } \\
\text { increase their market shares in India. }\end{array}$ \\
\hline
\end{tabular}

Source: Author 


\section{CHAPTER 7}

\section{NUMERICAL ESTIMATES AND SCENARIO OUTLINES}

\subsection{Introduction}

The previous chapter provides qualitative information on the EU market and the emerging Eastern markets for table grapes. In this chapter, the focus is on quantitative information on the different markets. This quantitative information is presented as numerical estimates of current and future indicators to complement the qualitative information.

In the next section, three scenarios are presented and discussed. The impact of changes in market distribution under each scenario on farm financial viability is determined using a farm-level model. The performance of farms under each scenario is analysed in a comparison format using IRR as a performance indicator. The farm-level models are then linked to a sector model to evaluate the general effect of diversifying the markets in the table grape industry. The general performance of the table grape industry in each scenario is measured in terms of value growth (i.e. the worth of the industry).

\subsection{Scenario 1: Continuation of the current market situation (85\% EU and $15 \%$ others)}

Figure 14 graphically represents market volume distribution under Scenario 1. The volumes exported to emerging Eastern markets such as the Far East, the Middle East, and Asia are kept at $4 \%$ each. The bulk of South African volumes is exported to the UK and continental Europe, accounting for $85 \%$ of South Africa's total exports.

There are various factors that have promoted the current market situation, including (i) a sound understanding of traditional markets and well-structured retail sectors in traditional markets; (ii) a lack of understanding of emerging Eastern markets (South African exporters consider eastern markets as high-risk markets, and the price received does not compensate for the magnitude of market risk involved) and (iii) a favourable shorter distance between Europe and South Africa resulting in fewer shipping days, which has proven to be a strong comparative advantage to South Africa when compared with other southern hemisphere countries. 


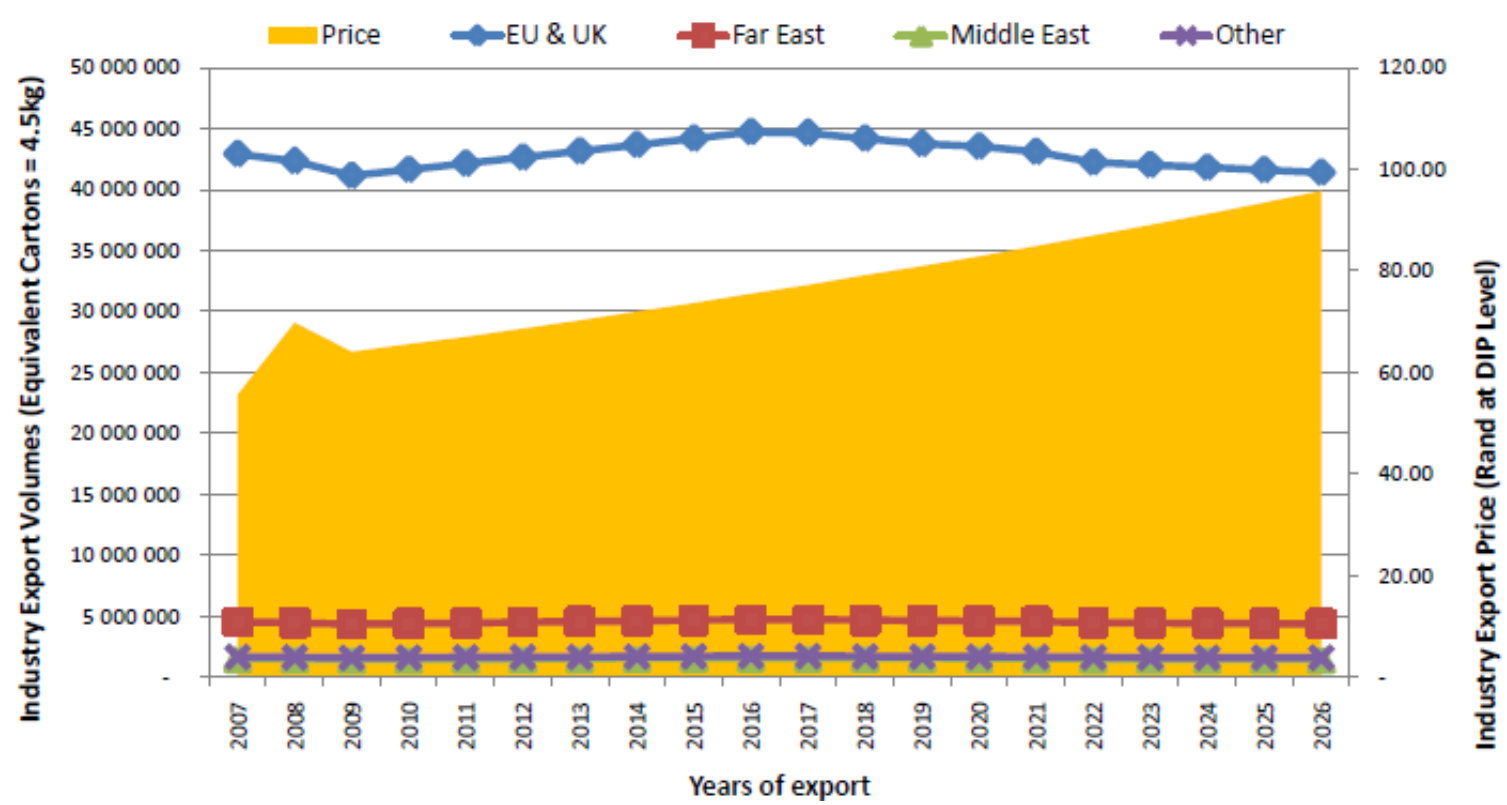

Figure 14: Table grape export market diversification outlook and industry price growth under Scenario 1

Source: Own calculations

\subsubsection{Sector model results under Scenario 1}

The financial analysis presented in the graph above reflects a pessimistic picture of the prospects of the table grape industry under Scenario 1. The sector model results show that the industry export price is growing at a steady rate of $2 \%$ per year, while industry export volumes are maintained at 50 million cartons per year (see Figure 14, above, and Annexure I: Table 1). The table grape export price increased by $30 \%$ in 2008 due to a shortage in volumes from southern hemisphere countries and a weaker rand against the pound and euro. Since then, the export price has dropped by $11 \%$ due to recession conditions that contracted the demand for table grapes in traditional markets. In the short term, the industry price is projected to decline by an average rate of $1 \%$ per year due to poor market conditions and low product demand. The price is expected to recover after three years as consumers start to regain their buying power. Consumer buying confidence is expected to regain its strength after 2011, and this will trigger more spending on fruits. In the medium term, the sector model results project an increasing industry price of $2.3 \%$ per year. This steadily increasing medium-term trend is stimulated by a production shift to more popular cultivars with more desirable characteristics, the weaker exchange rate (rand against the euro and pound) and investments in product-packaging innovation. The industry value is projected to grow by an average rate of $2 \%$ per year (see Annexure I: Table 1). 


\subsubsection{Farm-level model results under Scenario 1}

The farm-level model results reflect a disquieting situation compared to the sector results under Scenario 1. The model simulation shows that the average growth rate of the realised export price on the Western Cape farm is $2 \%$ while on the Northern region farm it is $3 \%$ per year (see Figure 15, below). The lower price growth rate is caused by strong competition from alternate southern hemisphere suppliers in traditional markets and increasing export costs. The other contributing factor to this poor price growth is poor market conditions that are rooted in stagnating consumption level in Europe and the compliance costs of increasing food safety and quality standards.

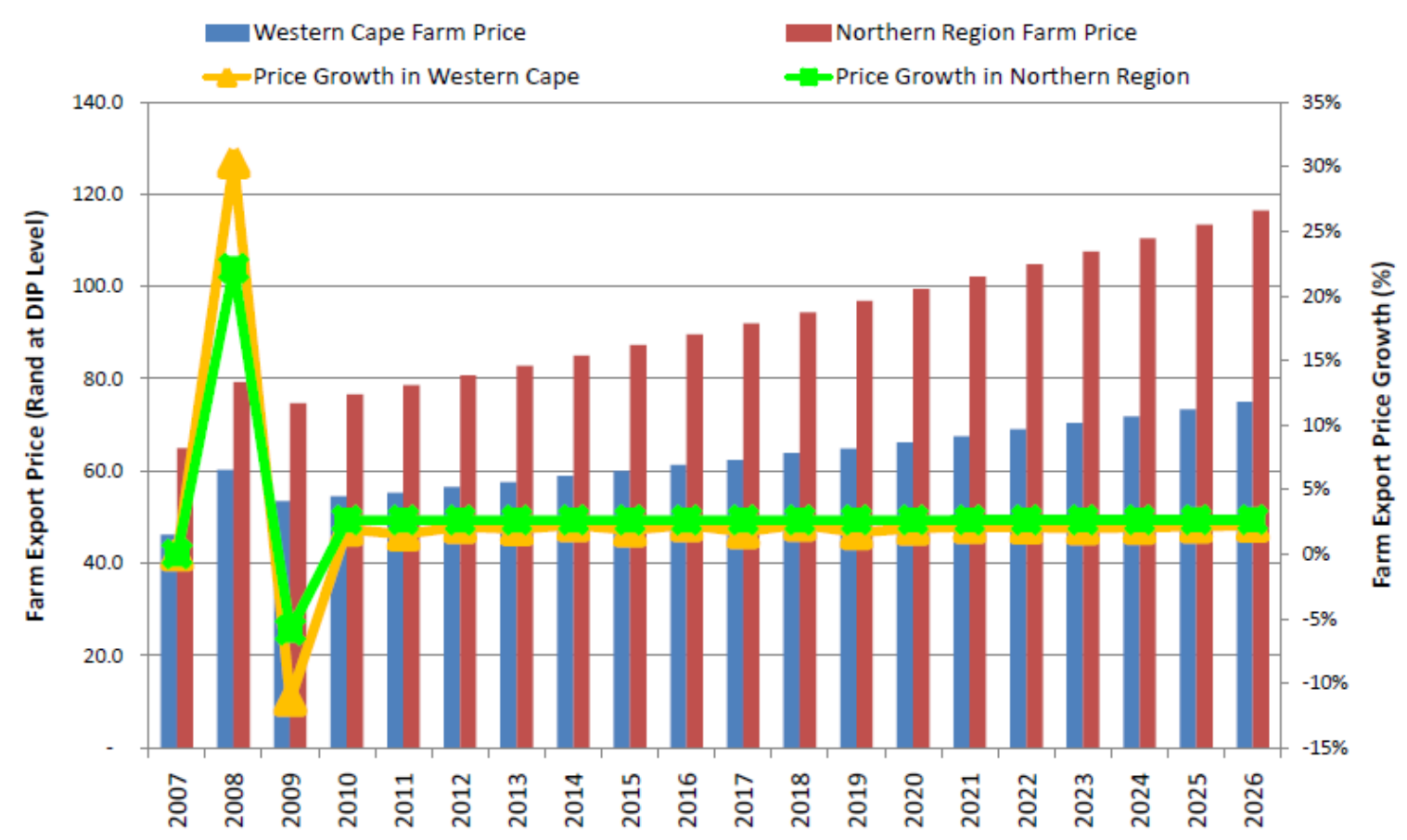

Figure 15: Realised export price growth for the Western Cape and Northern region farms under Scenario 1

\section{Source: Own calculations}

Under Scenario 1, the table grape farms' profitability is further weakened by constantly rising production costs. Production costs grow at a higher rate than the low growth rate of the farms' export prices. Labour and packaging inputs are the largest contributors to total farm production costs. The latter is the biggest worry for producers, as deforestation is taking place throughout the country. The chemical costs relating to production are projected to increase by an average rate of $4 \%$ per year, while packaging material will increase by $6 \%$ per year over the next five years(UAP, 2008; Nexus, 2008; BASF, 2008 and Kaap-Agri, 2008). 
The regional performance indicator (i.e. IRR) shows that Western Cape producers will suffer most under Scenario 1 in the next 20 years. The IRR for the Western Cape farm is simulated to be $16.88 \%$ (see Annexure C: Table 1), while for the Northern region farm, it is $22.62 \%$ (see Annexure D: Table 1). The lower IRR for the Western Cape farm is caused by constantly increasing production costs and low export price growth. The Western Cape farm faces high competition from Chile and Argentina as these two countries compete directly with Western Cape produce during their marketing time in Europe. The increasing export costs (e.g. shipping costs and overseas handling and distribution costs) also contribute to the low profitability of the Western Cape farm.

The Northern region farm displays a better IRR due to the high prices received from Europe prior to the Christmas period. The market competition during this time is not large, as the quantities exported from Namibia, Peru and Brazil are still relatively small and do not affect the market prices significantly. The Northern region farm enters the harvesting period two months earlier than the Western Cape farm, consequently receiving better export prices.

\subsubsection{Implications for the South African table grape industry}

Diminishing returns and stagnating export volumes will have a negative impact on the table grape industry and the country at large. The country will be faced with a rising unemployment rate as farm workers will lose their jobs due to the shrinking table grape industry (other fruit industry are less labour intensive as compared to table grape industry). The number of table grape producers has already started to decline and will continue to do so, largely as a result of the consolidation of farming units (SATI, 2009). Table grape producers are expanding their farm sizes in order to gain economies of scale, which will help mitigate the impact of rising production and export costs as well as stagnating export prices. Table grape producers are starting to diversify their farming enterprises and uproot some of their table grape vineyards, and plant other commodities such as wine grapes and citrus products. The diversification of enterprises on the farms helps producers mitigate the problems of farm cash flows. The diversification of farm enterprises will further strain the growth of the table grape industry under Scenario 1. 


\subsection{Scenario 2A: Slowly focusing on emerging markets (60\% EU and $40 \%$ others)}

Under Scenario 2A, table grape industry stakeholders acknowledge the need to redistribute export volumes away from traditional markets and sell them to developing markets. Stakeholders feel that redistribution should be done slowly to allow both exporters and producers an opportunity first to understand the operations and structures of emerging Eastern markets (i.e. Far East and Middle East). In this scenario, stakeholders argue that producers should not rush the redistribution process, but rather immediately focus their energy and resources on product differentiation and packaging innovation. The product innovation will provide South Africa with a competitive advantage, as they will be offering consumers a new product in the markets. Therefore, in this scenario, South African export volumes are slowly redistributed from Europe to other markets, with the distribution process taking 14 years before the desired market diversification targets are achieved.

The diagram in Figure 16, below, graphically represents the South African export market distribution under Scenario 2A. The emerging Eastern markets such as the Far East and Middle East will be absorbing $27 \%$ and $7 \%$ of South Africa's total exports, per year, respectively. The bulk of South African volumes (60\%) will still be exported to the UK and continental Europe.

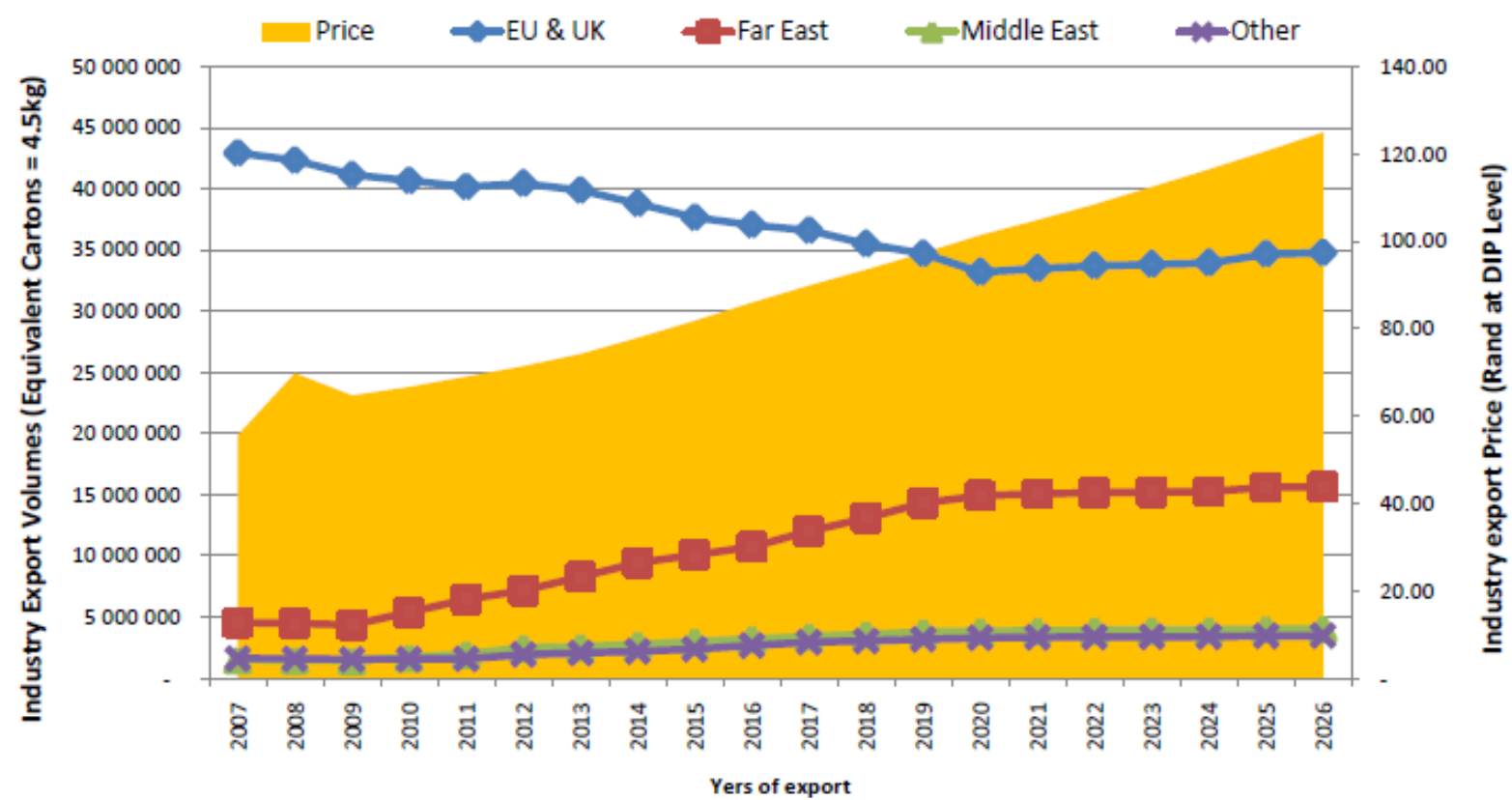

Figure 16: Table grape export market diversification outlook and industry price growth under Scenario 2A

Source: Own calculations 
The driving forces for Scenario 2A are divided into two groups: (i) push factors, which include (a) strong competition in traditional markets that are pushing South African producers to find alternative markets for their products, and (b) stringent technical and environmental barriers in traditional markets that are restricting export growth; and (ii) pull factors, which include (a) globalisation, which has stimulated the growth of formal retailers in emerging countries such as China and India - globalisation is also promoting life-style changes, as Asian and African consumers are starting to eat more healthy foods such as vegetables and fruits, and these present new trade opportunities for fruit exporting countries; and (b) stronger economic growth in Asian and African countries. Economic growth is facilitating the urbanisation rate in countries such as China and India, and also stimulating higher household incomes. The higher incomes mean consumers will be willing to buy expensive and luxurious products such as table grapes. The urbanisation rate has a tendency to bring people together in the main cities, consequently making it easier to supply these people as they live in one area rather than scattered over rural areas. The other driving factor in this scenario is trade liberalisation, which has promoted the opening of Asian markets to South Africa. Trade liberalisation aims to reduce trade barriers, thus stimulating a free and fair trade environment.

\subsubsection{Sector model results under Scenario 2A}

The European market has a large influence on industry export prices as the bulk (60\% of total export) of South African volumes are exported to Europe. Under Scenario 2A, the industry export price is projected to increase by an average rate of $4 \%$ per year (see Figure 17, below). The stronger industry price growth is noticed in the short term. The short-term price strength is supported by the relocation of export volumes from Europe to Eastern markets, and with the traditional markets being properly supplied, the result is smaller fluctuations in prices during the grape season. Furthermore, the export prices realised from Asian markets such as the Far East and Middle East are strengthening. These prices are boosted by improving consumer incomes due to strong regional economic growth in Asia. Consumers from Asian countries are less concerned with environmental issues, and this means production and export costs to Asian countries are lower than for European markets. South African producers export higher volumes to Asian markets and have also improved the quality of exported products. Asian importers realise South Africa's commitment and are willing to pay premium prices for high-quality products. They have switched to more popular cultivars with desired characteristics, which 
coupled with innovative packaging, have also had a positive effect on South African prices in the medium-term for both traditional and emerging markets.

Industry export volumes will increase by an average rate of $1.2 \%$ per year under Scenario $2 \mathrm{~A}$, and this increase is driven by factors such as improved yield per hectare and newly planted vines entering their full bearing capacity. The sustained industry export growth is supported by a growing consumption of table grapes in Asian and African markets. The consumption rate is projected to increase significantly in Asian markets due to increasing incomes and a growing need for fresh products (Promar International, 2008 and Rabobank, 2008). The short term is seen as a reshuffling period, where current volumes are relocated from traditional markets and distributed to emerging markets. The projected industry price and export volumes were simulated to produce the industry value under Scenario $2 \mathrm{~A}$. The industry value is estimated to increase at an average rate of 5\% per year (see Annexure I: Table 2).

\subsubsection{Farm-level model results under Scenario 2A}

The industry export price under Scenario $2 \mathrm{~A}$ is projected to be higher due to better volume distribution and more focus on producing and exporting popular cultivars with desired market characteristics. The farms' realised export prices are expected to be higher when compared with Scenario 1. The farm-level model results show that the Northern region farm's table grape export price will increase at an average rate of $4 \%$ per year. The Western Cape farm's table grape export price will increase by an average rate of $5 \%$ per year in the same period. This strong growth in the Western Cape farm's price indicates that this region will benefit strongly if the industry diversifies its products to emerging markets. This is largely because of the strong competition faced by Western Cape producers in traditional markets, and this competition will be lowered if a certain percentage of export volumes is relocated to Eastern markets.

The stronger price growth for the Western Cape farm is experienced in the short term as it redistributes its volumes to Eastern markets, but this is lowered by Chile and Argentina in the long term, as they fill up the gap left by South Africans in Europe. The seeded cultivars from the Berg and Hex River are harvested two to three weeks earlier than Chile's seeded cultivars (SATI, 2008a and SHAFFE, 2008). Under better market diversification conditions, this will mean that South African seeded cultivars will be enjoying seeded niche markets in Europe without these being oversupplied, which was the case under Scenario 1, where South African seeded cultivars were oversupplying the markets during their low-competition window period. 


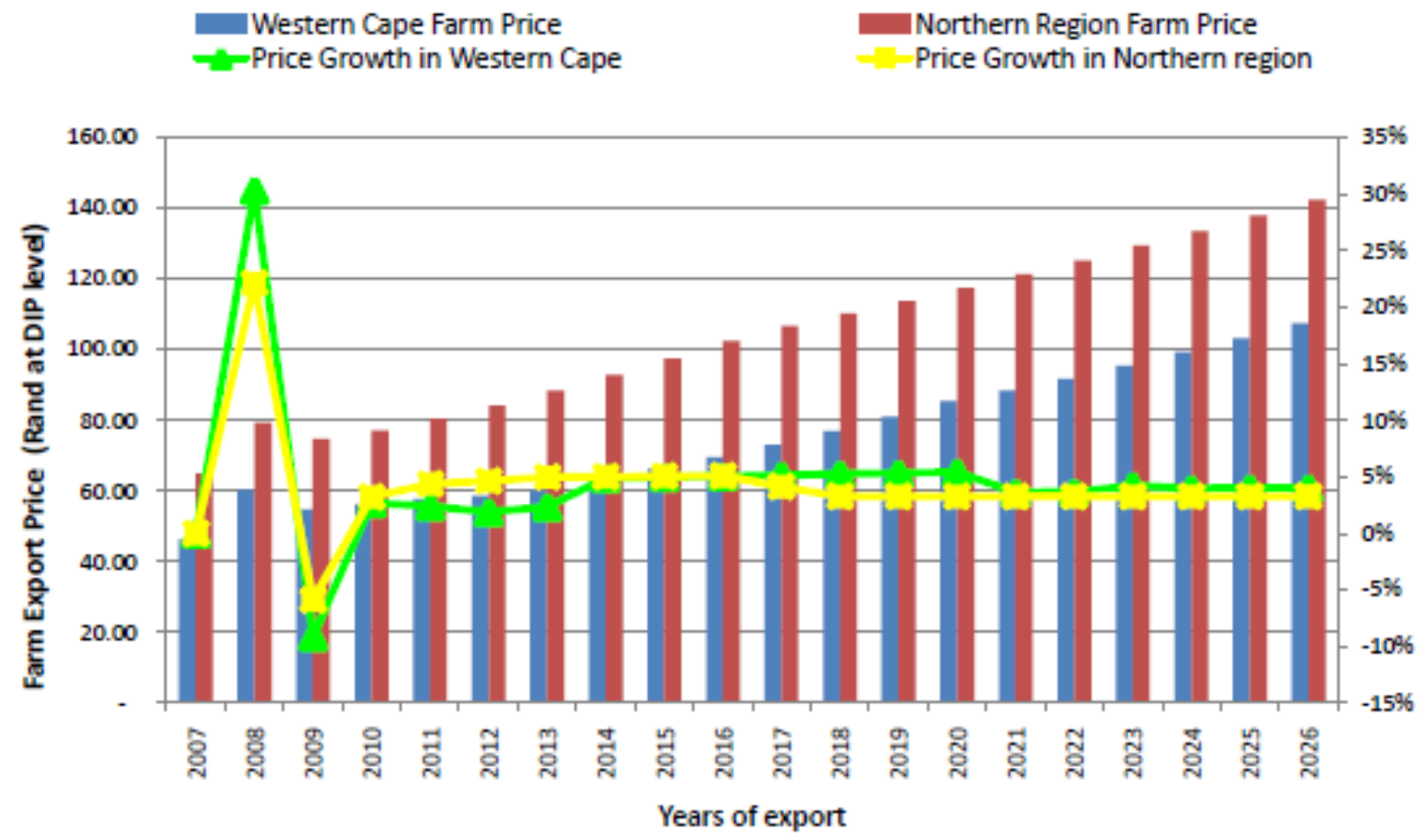

Figure 17: Realised export price growth for Western Cape and Northern region farms under Scenario $2 \mathrm{~A}$

Source: Own calculations

The production input prices are expected to be the same as in Scenario 1, except for establishment costs. The establishment costs under Scenario 2A will be higher, as early replacements of less-profitable cultivars will be conducted in an attempt to have more marketdriven cultivars. The replacement costs will have a significant impact on farm cash flow, but the higher returns are expected to compensate for the replacement costs in the medium to long term (see Annexure E for the Western Cape farm, and Annexure F for the Northern region farm).

Using IRR as the regions' performance indicators, the farm model calculted the IRR for the Western Cape farm as 23.65\% (see Annexure E: Table 1) and for the Northern region farm as 26.52\% (see Annexure F: Table 1). The IRR results confirm that mid-and late-season regions such as the Hex River and Berg River will benefit (largely due to properly supplied markets) if the industry diversified its volumes to emerging markets. The IRR for the Western Cape farm increased from $16.88 \%$ to $23.65 \%$ for this scenario, while for the Northern region farm, there was no significant change in the IRR percentage (increased from $22.62 \%$ to $26.52 \%$ ). The reason for this is that the Northern region producers face less competition in European markets during 
their marketing window periods, as their direct competitiors (e.g. Peru, Namibia and Brazil) export small quantities during this period. Therefore, diversifying markets will have less impact on Northern region producers compared to the high impact on their counterparts in the Western Cape.

\subsubsection{Implications for the South African table grape industry}

The future of the table grape industry under Scenario 2A appears promising when compared to the industry picture that was revealed under Scenario 1. In this scenario, the industry grows when measured in terms of volumes exported and area under table grape production. The increasing area under table grape production indicates that more jobs are created by the table grape industry, thus more people are employed. Therefore, in this scenario, the unemployment rate is reduced and the socio-economic status of South Africans is enhanced. The increasing industry price and growing export volumes result in an increasing industry value (increasing the industry's percentage contribution to the country's GDP).

\subsection{Scenario 2B: Rapidly focusing on emerging markets (60\% EU and $40 \%$ others)}

Scenario 2B has the same characteristics as Scenario 2A, and is driven by more or less similar forces. The main difference between the two is the time taken to achieve the set distribution targets (i.e. export $60 \%$ to the EU and $40 \%$ to other markets). Scenario $2 \mathrm{~B}$ projects that increasing competition from alternative southern hemisphere suppliers will have a servere impact on the South African table grape industry if the industry does not explore and develop new markets for their products at a faster rate than what was visualised in Scenario 2A. Scenario 2B is largely encouraged by improving market intelligence that enables exporters to analyse and understand emerging markets faster and more thoroughly. The availability of this information will help exporters to identify market niches in emerging markets and therefore supply the developing markets successfully. Under Scenario 2B, some of the South African export volumes are rapidly removed from traditional markets and shipped to emerging markets, and the redistribution process takes nine years before the desired market diversification targets are achieved. 
Figure 18, represents the South African export market distribution under Scenario 2B. It is evident from the graph that South African export volumes are adequately diversified to all markets according to their consumer size and economic growth. Exports to the Far East and Middle East grow rapidly, while exports to Europe show a decline. When the market distribution is completed, the European markets will absorb $60 \%$ of South Africa's total export volumes, the Far East will absorb 27\%, the Middle East 7\% and other markets will absorb the rest (which is $6 \%$ of total export volumes).

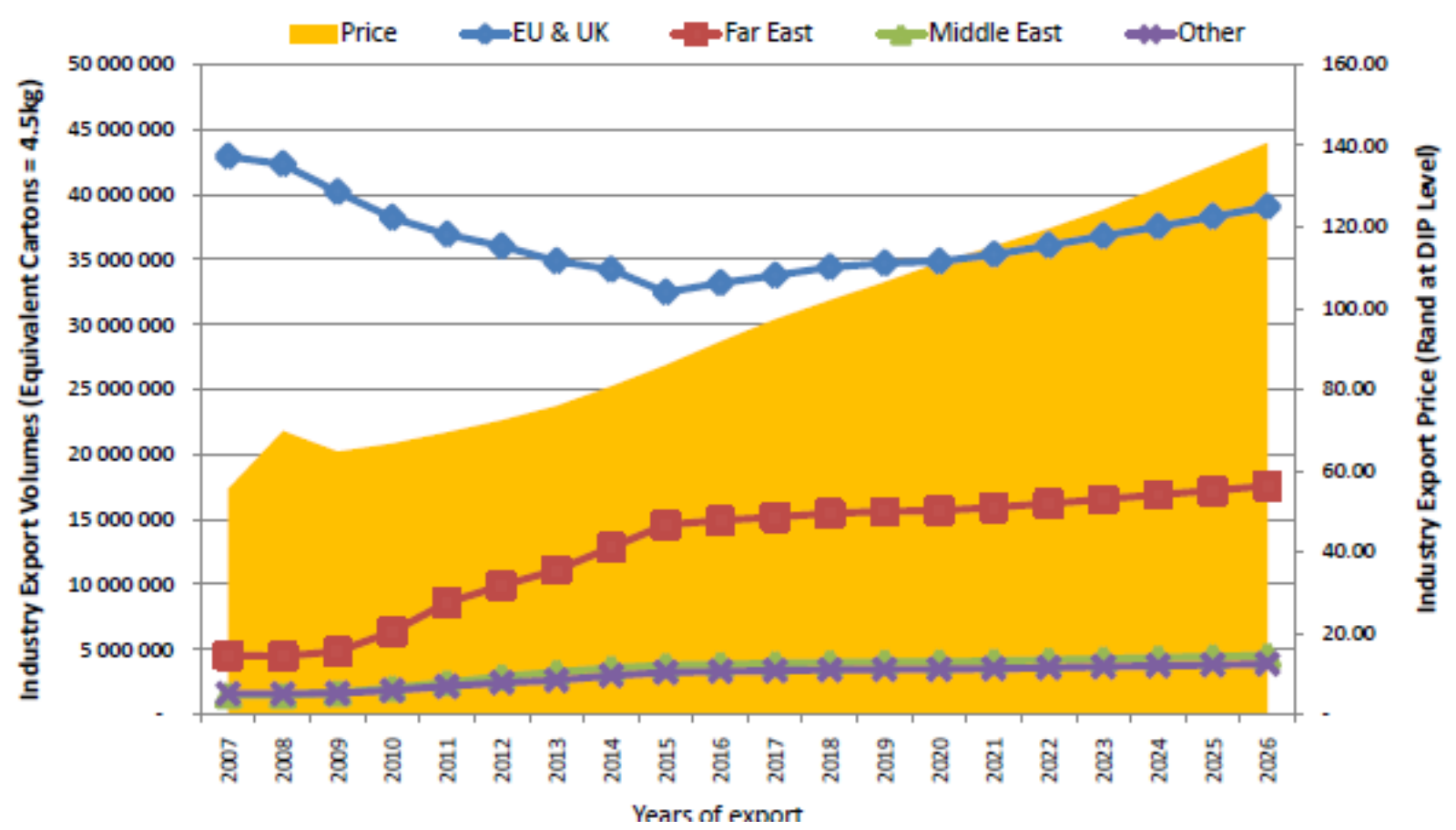

Figure 18: Table grape export market diversification outlook and industry price growth under Scenario 2B

Source: Own calculations

As in Scenario 2A, this scenario is driven by globalisation, trade liberalisation, availability of market intelligence information and stronger economic growth in Asian and African countries. The EU's diminishing returns to South African producers motivate producers to find suitable markets for their products. The constantly increasing export volumes from alternative suppliers push South African producers to explore new markets for their products. 


\subsubsection{Sector model results under Scenario 2B}

The financial analysis of drivers for Scenario 2B shows a progressive and prosperous table grape industry. The industry export price is projected to increase by $5 \%$ per year under Scenario $2 \mathrm{~B}$. The stronger price growth is supported by (i) rapid redistribution of volumes away from Europe to emerging Eastern markets; (ii) the availability of reliable market intelligence that enables South African exporters to identify market niches in emerging markets and supply these developing markets successfully, and (iii) the weaker exchange rate, which also strengthens the table grape prices that are recieved from Europe. The sustained price growth rate is also stimulated by more focus on producing popular cultivars with desirable characteristics and more investment in product-packaging innovation. The higher growth in the industry price is noticeable in the short term when volumes are relocated from the EU to Eastern markets.

The industry's export volume shows an increasing trend under Scenario 2B. The sector model results reveal an export growth rate of $2 \%$ per year. This promising export growth rate is promoted by (i) large numbers of vines entering their full bearing capacity in the medium term; (ii) volumes being relocated from local markets to export markets, as international markets pay better prices compared with local markets and (iii) new cultivars yield more compared with old cultivars, which means more will be produced per area planted. The prospering international markets and increasing returns will encourage producers to increase their production, resulting in increased export volumes. The red and black seedless varieties are expected to lead the growing production in the short and medium term as these gain popularity in the emerging Eastern markets and in Eastern Europe. Under Scenario 2B, the table grape industry's value is expected to grow by an average rate of $6 \%$ per year (see Annexure I: Table 3).

\subsubsection{Farm-level model results under Scenario 2B}

The farm export price for the Northern region is forecast to grow at an average rate of 5\%, while the farm export price for the Western Cape is estimated to grow at an average rate of $6 \%$, from a low base. This strong growth in the Western Cape farm's price indicates that this region will benefit strongly if the industry diversifies its products to emerging markets. This is largely because of the high competition faced by Western Cape producers in traditional markets, and this competition will be lowered if a certain percentage of export volumes is relocated to Eastern 
markets. The stronger price growth of the Western Cape farm is experienced in the short term as they redistribute their volumes to Eastern markets, but this is lowered by Chile and Argentina in the long term, as they fill the gap left by South Africa in Europe. The shift in focus towards higher yielding and popular seedless cultivars has positive effects on South African export prices. The intensive investments in quality produce and packaging innovation also stimulate the higher export prices for South African farms (see Figure 19, below).

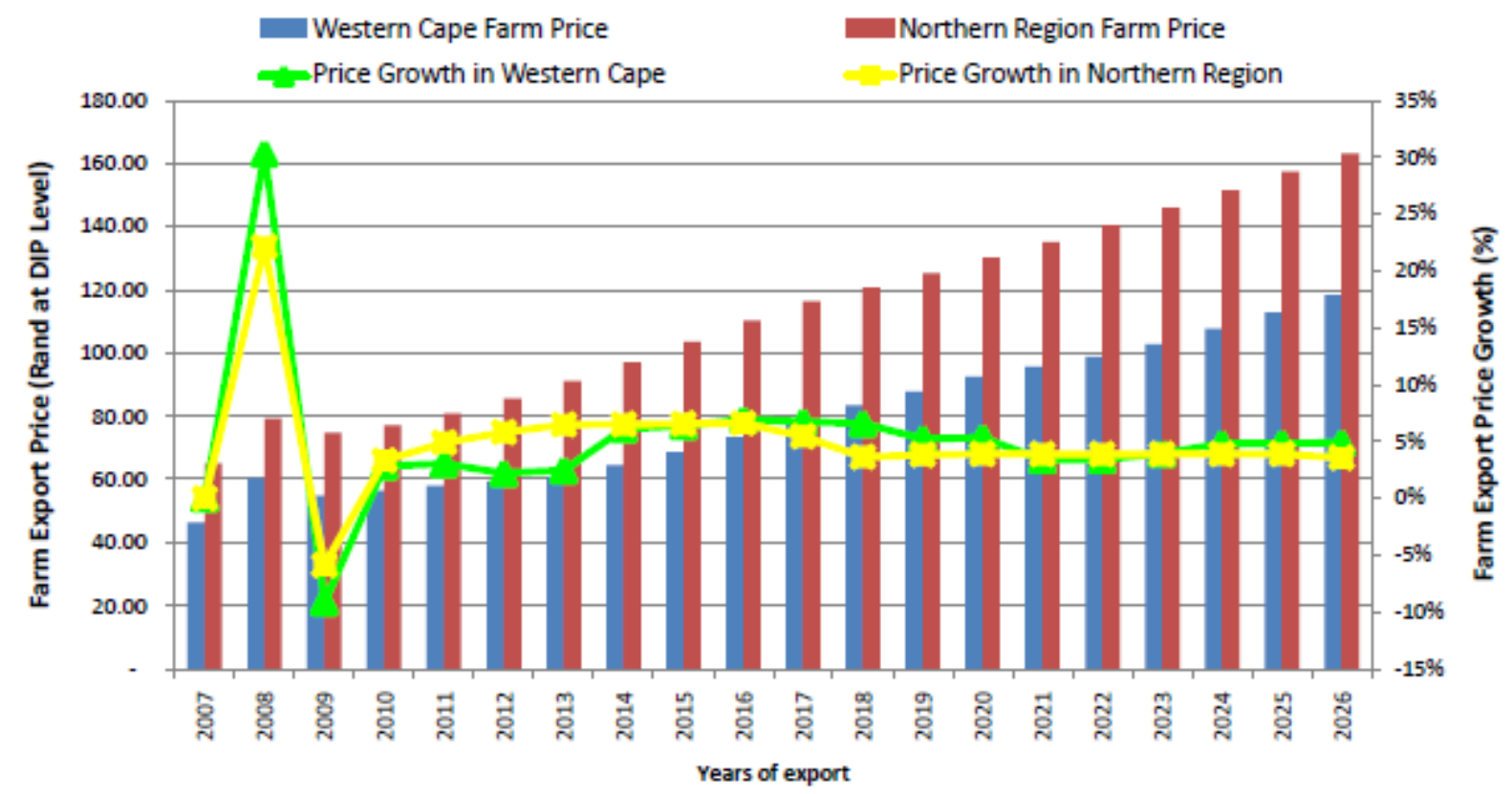

Figure 19: Realised export price growth for Western Cape and Northern region farms under Scenario 2B

Source: Own calculations

Using IRR as the regions' performance indicator, the farm model calculted the IRR for the Western Cape farm as $28.92 \%$ and for the Northern region farm as $27.02 \%$ (see Annexure G: Table 1 for the Western Cape farm, and Annexure H: Table 1 for the Northern region farm). The IRR results confirm that mid and late South African regions such as the Hex River and Berg River will benefit largely if the industry diversifies its volumes to emerging markets. This is because of the strong competition it faces under current market conditions. 


\subsubsection{Implications for the South African table grape industry}

The benefits of diversifying the export markets and replacing non profitable cultivars with new popular cultivars includes (i) increasing export prices, thus increasing the industry's value (larger industry percentage contribution to the country's GDP); (ii) increasing export quantities, resulting in greater job creation (i.e. uplifting the social and economic status of South Africans) and supporting government's vision of reducing the unemployment rate and eradicating poverty; and (iii) by efficiently utilising both European and Eastern markets, the industry not only stabilises price fluctuations, but also complements the effort of government to open new markets for South Africa. This will encourage government to further negotiate better trade agreements with Eastern countries.

\subsection{Summary}

\subsubsection{Sector model results: comparison of all three scenarios}

The graph in Figure 20, below, compares industry gains under all three scenarios. The average industry export volumes increase from 50 million cartons per year under Scenario 1 to 53 million cartons per year under Scenario 2A and 56 million cartons per year under Scenario 2B. The industry export price increases by an average rate of $2 \%$ per year under Scenario 1, 4\% per year under Scenario 2A, and 5\% per year under Scenario 2B. This suggests that the table grape industry will be better off under Scenario 2B, validating the benefits of having adequately diversified export markets. 


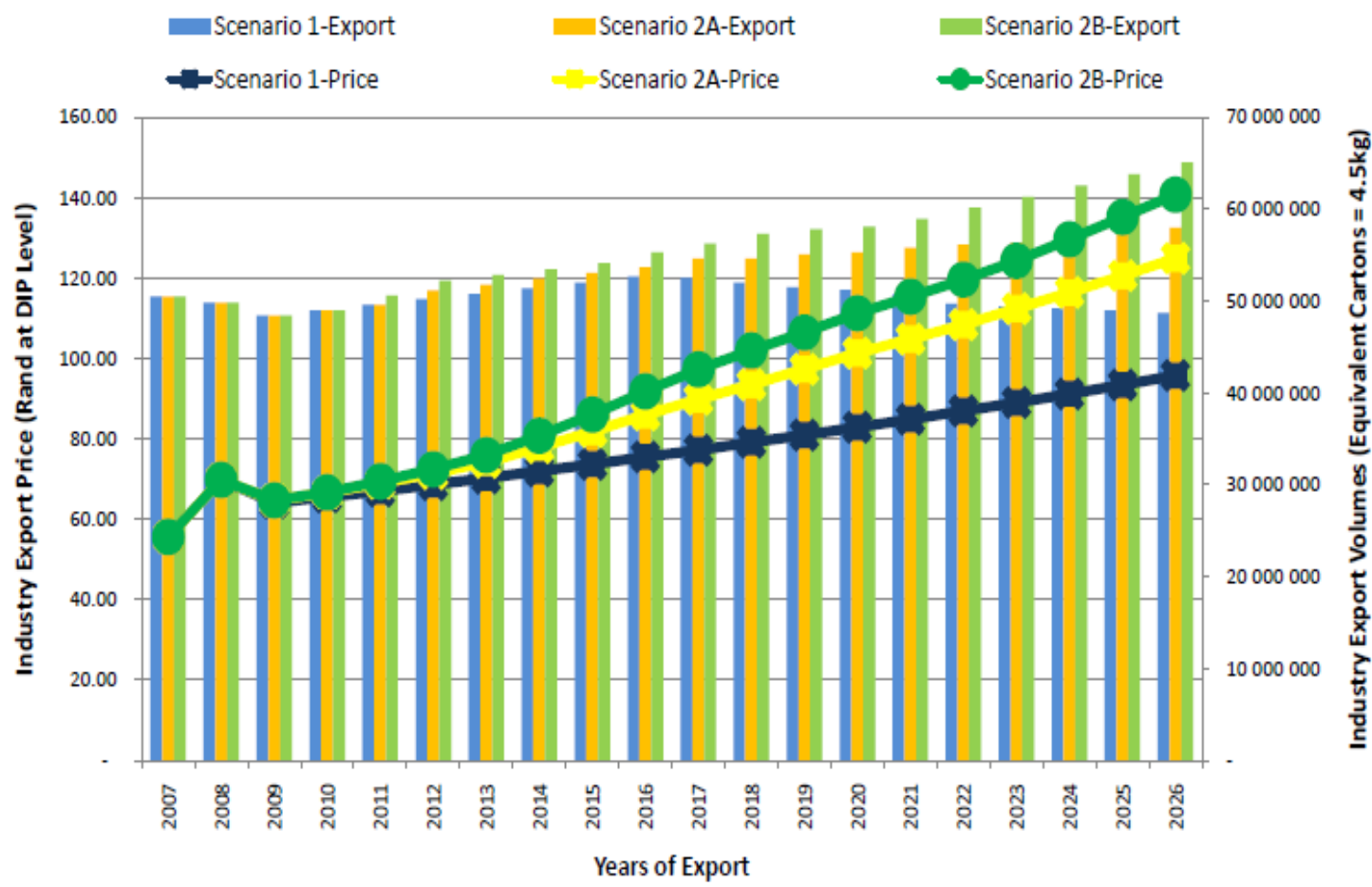

Figure 20: Industry export volumes and price growth under all three scenarios Source: Own calculations

\subsubsection{Farm-level model results: comparison of all three scenarios}

Table 12, below, compares the perfomances of typical Western Cape and Northern region farms under all three scenarios. The stronger IRR growth for the typical Western Cape farm under Scenario 2A and Scenario 2B compared with Scenario 1 is due to the increasing export price and the increasing yield under these scenarios. The yield per hectare of the Northern region farm does not vary significantly under all three scenarios. The Northern region farm is a price setter in the markets, as it commences its harvest and export seasons two months ealier than its Western Cape counterpart. This means that its production strategy should facilitate early cultivar maturation and premium quality so that the price is set at the highest level. In the Western Cape, producers are price takers and they have less power in setting the market price level as they enter the market late in the season. The Western Cape production strategy is to promote a higher yield per hectare, thus creating a high pack-out percentage to obtain large export volumes. Figure 21, below, reflects the production strategies practised by the Western Cape and Northern region farms. 
Table 12: Farm-level results for Western Cape and Northern region farms under all three scenarios

\begin{tabular}{|c|c|c|c|c|c|c|}
\hline \multirow[t]{2}{*}{ Indicator } & \multicolumn{3}{|c|}{ Western Cape Farm } & \multicolumn{3}{|c|}{ Northern Region Farm } \\
\hline & Scenario 1 & $\begin{array}{l}\text { Scenario } \\
2 \mathrm{~A}\end{array}$ & $\begin{array}{l}\text { Scenario } \\
\text { 2B }\end{array}$ & Scenario 1 & $\begin{array}{l}\text { Scenario } \\
2 \mathrm{~A}\end{array}$ & $\begin{array}{l}\text { Scenario } \\
2 \mathrm{~B}\end{array}$ \\
\hline $\begin{array}{l}\text { Average growth/year } \\
(\%): 20 \text { yrs }\end{array}$ & $2 \%$ & $4 \%$ & $5 \%$ & $3 \%$ & $4 \%$ & $5 \%$ \\
\hline $\begin{array}{l}\text { Average price } \\
\text { growth } / \text { year }(\mathrm{R} / \text { carton }= \\
4.5 \mathrm{~kg}): 20 \mathrm{yrs}\end{array}$ & R64 & R78 & $\mathrm{R} 83$ & R96 & $\mathrm{R} 112$ & R120 \\
\hline IRR & $16.8 \%$ & $23.6 \%$ & $28.9 \%$ & $22.6 \%$ & $26.5 \%$ & $27.02 \%$ \\
\hline Replacement intensity & $\begin{array}{l}\text { No } \\
\text { replacement }\end{array}$ & $\begin{array}{l}\text { Within } \\
\text { first } 14 \\
\text { years }\end{array}$ & $\begin{array}{l}\text { Within } \\
\text { first nine } \\
\text { years }\end{array}$ & $\begin{array}{l}\text { No } \\
\text { replacement }\end{array}$ & $\begin{array}{l}\text { Within } \\
\text { first } 14 \\
\text { years }\end{array}$ & $\begin{array}{l}\text { Within } \\
\text { first nine } \\
\text { years }\end{array}$ \\
\hline $\begin{array}{l}\text { Increased yield per } \\
\text { hectare }\end{array}$ & $0 \%$ & $2.9 \%$ & $5.7 \%$ & $0 \%$ & $0.5 \%$ & $1.4 \%$ \\
\hline
\end{tabular}

\section{Source: Own calculations}

The diagram below (Figure 21) shows that the higher the product quality, the higher the expected price. The Northern region farm adopts a production strategy that promotes high quality, while the Western Cape farm's production strategy is to promote a higher yield per hectare, and thus a high pack-out percentage to obtain large export volumes. It is this production strategy that results in an increasing yield per hectare for the Western Cape farm under Scenarios 2A and Scenario 2B. 


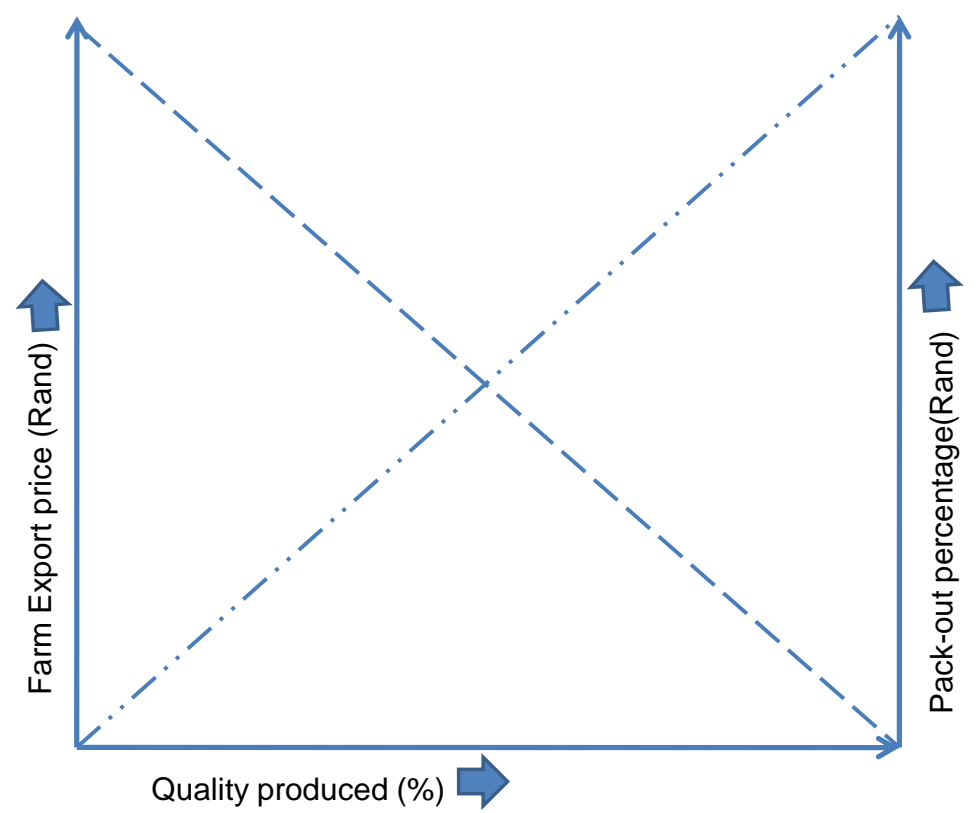

Figure 21: Production strategies for producing high quality export table grapes

Source: Capespan, 2008: 1

The following section summarises the effect of replacement costs for both farms under different scenarios. Figure 22, below, presents the margins before capital expenditure for the Western Cape farm. It is clear from the graph that the Western Cape farm's income will decline under Scenario 1, due to diminishing export prices and production, and export costs increasing at an average rate that exceeds the average growth rate of export prices. Under Scenarios $2 \mathrm{~A}$ and 2B, the farm's income is much improved compared with Scenario 1, due to its focus on popular cultivars with desirable market characteristcs, and investments in product differentiation and packaging innovations. The replacement costs under Scenarios $2 \mathrm{~A}$ and $2 \mathrm{~B}$ do not have the same impact on the farm's margins. The reasons for this are (i) plant material and other establishment costs are lower compared with the Northern region and (ii) the area replaced (size of cultivar blocks) is not large compared with the Northern region farm. 


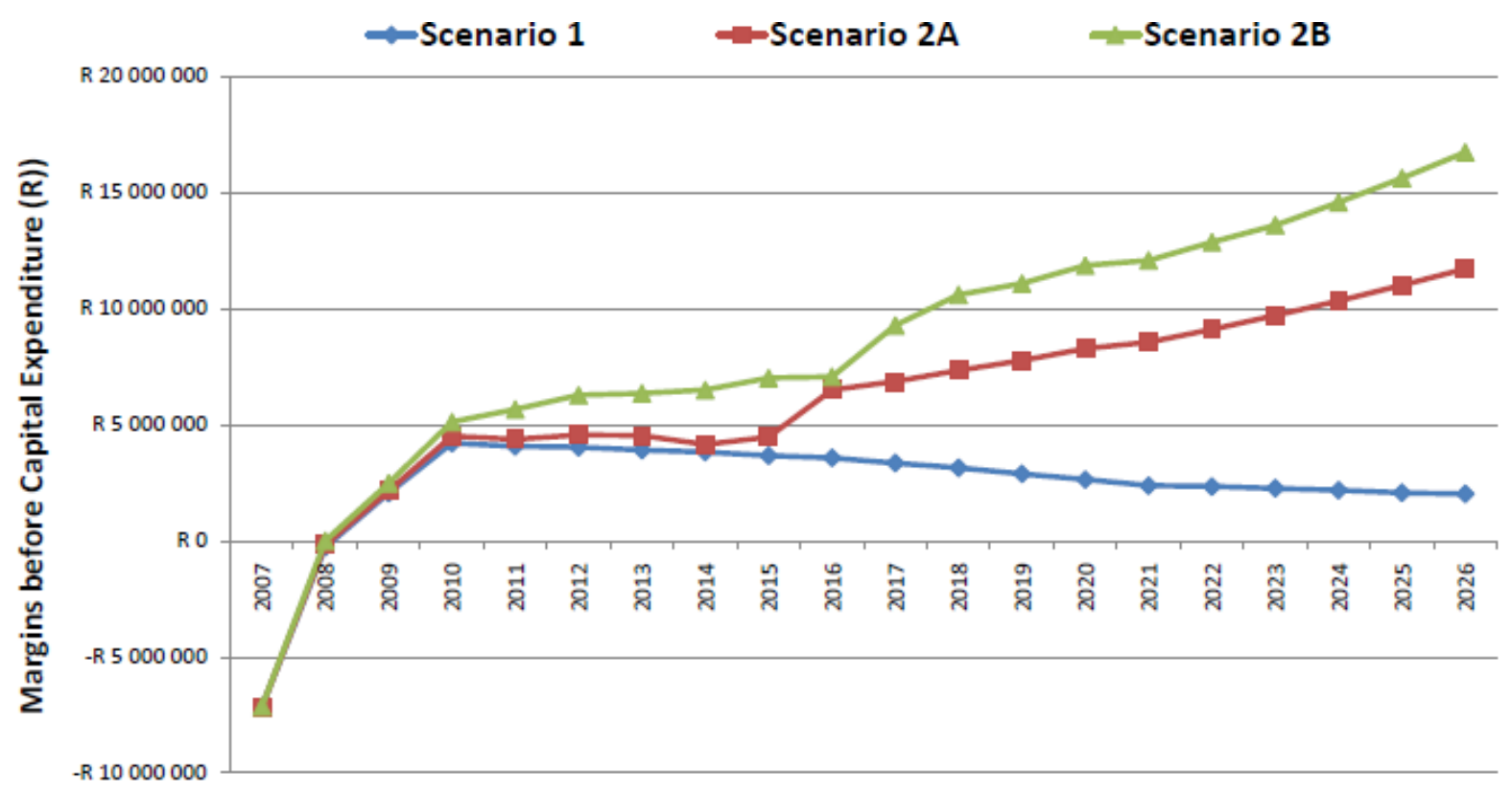

Figure 22: Impact of the replacement of less popular cultivars in terms of Scenarios 2A and 2B on margin before capital expenditure in the Western Cape

Source: Own calculations

Figure 23, below, represents the farm's margin before capital expenditure for the Northern region. As with the typical Western Cape farm, the Northern region farm's income declines under Scenario 1 due to production and export costs increasing faster than the export price. Under Scenario 2A, the farm's margin increases at a relatively stable rate due to better export prices and a shift to more popular cultivars. Under Scenario $2 \mathrm{~B}$, the impact of replacement processes is significant as the farm's returns are lower than those of Scenarios 1 and $2 \mathrm{~A}$ in the short term (see Figure 23). The reasons for the farm's low return are the high replacement costs (i.e planting material and labour costs) and the shorter replacement period (within nine years). However, the financial benefits of the replacement process in the short term is noticable in the medium term, where the farm's income under Scenario 2B grows way above the farm's income recorded under Scenario 1 and $2 \mathrm{~A}$. 


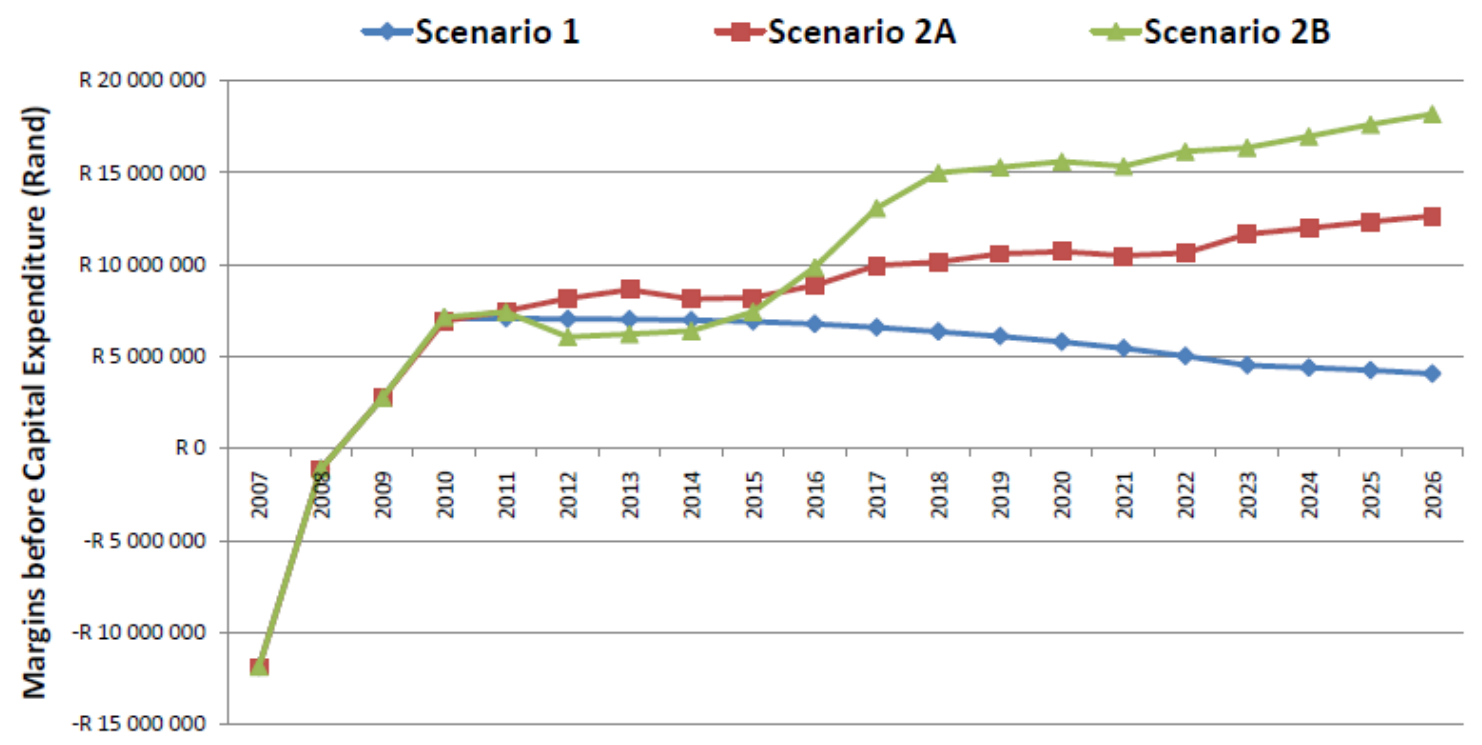

Figure 23: Impact of the replacement of less popular cultivars in terms of Scenarios 2A and 2B on margin before capital expenditure in the Northern region

Source: Own calculations

\subsection{Conclusions}

The financial analysis of all three scenarios shows that the South African table grape industry will be better off under Scenario 2B compared with Scenario 1. Under this scenario, the table grape producers are faced with growing trade opportunities because of the availability of emerging Eastern markets. In the short term, the redistribution of exports from traditional to emerging Eastern markets will have a positive effect on the South African export price realised, but this could be minimised in the medium to long term when South African competitors increase their exports to fill the gap left by South Africa in Europe.

The medium-term impact on the South African table grape industry includes expanding trade opportunities to emerging markets, strengthening the average export price and reduced market risk due to better export diversification. Under a diversified market environment, the table grape industry will create more employment and the socio-economic status of farm workers will be improved. 


\section{CHAPTER 8}

\section{SUMMARY, CONCLUSIONS AND RECOMMENDATIONS}

\subsection{Summary}

Chapter 1 explains that the South African table grape industry is more than 120 years old and currently exports just over 50 million cartons $(4.5 \mathrm{~kg})$ of table grapes per season to global markets. Over the last two decades, South Africa has managed to diversify only $15 \%$ of its total exports away from the UK and continental Europe. The chapter further explains that SATI wants to expand the industry's export volumes to Eastern markets due to increasing competition in European markets from alternate southern hemisphere suppliers, and constantly increasing food safety and quality standards in Europe. The new industry strategy aims to diversify the industry's current risk profile in order to improve and protect the industry's position in the global table grape markets. The chapter proceeds by explaining the purpose and objective of conducting this study, which is to investigate the viability of specific export market diversification scenarios. The general objective of this study is to develop a deterministic farm-level model based on accounting principles as a tool for simulating and analysing the impact of changes in markets on the financial viability of farms under different scenarios.

The second chapter of this study presents a literature review of scenario development relating to strategic management theory. Strategic management theory reveals that a range of future planning tools have emerged over many decades to assist managers in preparing for future unexpected outcomes. Scenario development is one of the future planning tools that has proven to be effective in many companies. The literature on scenario development suggests that the primary advantage of scenarios is to be able to represent the views of several industry stakeholders and expectations at the same time. Secondly, better than any other tools, scenarios offer the possibility of integrating various kinds of data in a consistent manner. In addition, the literature review shows that there are different approaches to developing scenarios, which demonstrates that there is, as yet, no consensus on the best approach to use. 
In Chapter 3, background information on farm-level modelling and simulation was given. The background information showed that there are two types of farm modelling, namely stochastic and deterministic modelling. There are two approaches that can be followed when building these models, the normative and positive approaches. The objective of this study was to develop a tool that would enhance the understanding of the table grape industry under different scenarios; therefore, a descriptive model was required, and the model needed to be oriented towards behavioural variability. From this it was decided that a deterministic type of model would be built, following a positivistic approach based on actual behavioural trends as estimated from actual historic farm-level data.

The study's methodology is discussed in Chapter 4. This chapter also explains that scenario planning was adopted as a tool to investigate the viability of expanding South African table grape export volumes to Eastern markets, as well as the potential risk of retaining current market distributions. The chapter further explains that the study uses financial farm-level modelling to determine the profitability of farms under each scenario that is developed. The financial farm model makes use of IRR as the farms' performance indicator under each scenario. IRR is used to rank several prospective scenarios an industry is considering, and assuming all other factors are equal among the various scenarios, the scenario with the highest IRR will probably be considered the best and will be undertaken first.

In Chapter 5, background information on the South African table grape industry was given. It was pointed out that South African table grapes are cultivated in five production regions, namely: the Hex River, the Berg River, the Olifants River, the Orange River and the Northern Province. These regions differ in terms of geographical allocations, soil characteristics and climatic conditions, which see South Africa enjoying a long season, from November until late May. The diverse climates allow South Africa to cultivate different varieties that meet the demands of different international markets. The top table grape cultivars planted in South Africa include the following, together with their relevant percentages of total hectares occupied: Red Globe - 10\%, Thompson Seedless - 10\%, Crimson Seedless - 10\%, Prime Seedless - 9\%, Sugraone $-9 \%$, Flame Seedless $-9 \%$ and Dauphine $-8 \%$. The chapter further explains that the existing table grape industry largely supplies European markets, and this high dependency has shaped South Africa production patterns to suit mainly the needs of traditional markets. The current cultivar profile does not fully meet the requirements of Eastern markets, which demand cultivars with a large berry size, crispy character and a longer shelf life. 
The market information given in Chapter 6 shows that traditional markets have become difficult and costly to supply, due to strict quality and food safety regulations. These regulations are the driving forces behind the increasing costs of production, and exports that have resulted in declining farm incomes. On the other hand, emerging Eastern markets, measured in terms of economic growth, are displaying new trade opportunities, spending ability, retail sector growth and infrastructural improvements. The emerging Eastern markets are less concerned with food safety and phytosanitary requirements compared with Europe, but they are more protected by tariff duties. They are also socio-economically and psychologically different from traditional markets. Gaining an improved understanding on these differences is a key tool to enhancing the producers' capacities to supply these markets successfully.

In Chapter 7, a numerical estimation of future trends and scenario outlines is presented and discussed in detail. This chapter includes the an analysis of the farm-level model's results under each scenario, and their implications on South African table grape farms. The financial analysis shows that the table grape industry will be worse off if they continue with the current market distribution. This is explained by the Scenario 1 results, indicating (i) declining returns due to saturated traditional markets; (ii) a shrinking industry due to the decreasing area under table grape production, and producers withdrawing from table grape production as they cannot maintain their farms; and (iii) declining employment as producers reduce their production and try to cut down on costs. These signs suggest that the table grape industry should start diversifying their export markets.

Furthermore, the analysis shows that the table grape industry will benefit strongly if a significant share of the export volumes are relocated from traditional to emerging Eastern markets. Scenarios $2 \mathrm{~A}$ and $2 \mathrm{~B}$ reflect a future world where export volumes are adequately distributed to both traditional and emerging markets. The sector model's results show that the industry price will grow by an average rate of $5 \%$ per year under Scenario $2 \mathrm{~B}$. Industry volumes will increase by an average rate of $2 \%$ per year. The farm-level model calculated the IRR for the Western Cape typical farm as $28.9 \%$ and for the Northern region farm as $27.02 \%$ under Scenario $2 \mathrm{~B}$. The higher IRR values under Scenario $2 \mathrm{~B}$ are the results of increasing yields per hectare on the Western Cape farm, coupled with the strong export price received in the short term when the industry relocates some volumes away from Europe to Eastern markets. The higher farm returns 
are also promoted by a shift to new cultivars with desirable market characteristics and an improvement in product-packaging innovation.

\subsection{Conclusions}

Answering the study's research question entailed investigating the viability of specific export market diversification scenarios. The aim was to evaluate the potential impact on the table grape industry if export volumes were to be relocated from traditional to emerging markets, and the potential risk if the industry were to maintain the current market distribution. The scenario development process was used as a planning tool in this study, and farm-level modelling was used to simulate and analyse the impact of changes in markets on the financial viability of farms under different scenarios.

An analysis of factors shaping the South African export sector shows that the table grape industry can no longer afford to send large export quantities predominantly to its traditional markets, due to increasing competition and diminishing market prices. Furthermore, the financial analysis shows that continuing with the current market diversification will have a negative impact in the industry, as farm returns, employment and farm units will decline under this scenario (i.e. Scenario 1). The farm-level model's results indicate that the table grape industry would be better off if export volumes were redistributed to other markets away from Europe. This is evident when looking at Scenario 2B's results. This scenario yields the highest IRR due to stronger price and export growth. The industry risk profile is lowered under Scenario $2 \mathrm{~B}$, due to better market diversification.

\subsection{Recommendations}

It is evident that Scenario 2B will bring the most benefits to the table grape industry, and the industry should implement this in order to regain its market share of global markets. However, there are actions that need to be taken if the industry wishes to remain a competitive supplier of quality table grapes to global markets. These include:

- Improve transparency in information sharing, which has been the industry's weakest point since deregulation. 
- Focus on developing innovative products (i.e. cultivate new varieties) for developed and emerging markets in order to retain global market share, and invest in promotional activities, especially those of a generic nature.

- Conduct more scientific and market research to find new cultivars, and understand the operations of emerging markets. 


\section{REFERENCES}

Adriaen. D., Kleynhans. T.E. and Tollens. E.A. 2004. A comparison between South African Agricultural Export to the European Union and those of other selected Southern Hemisphere countries. Agrekon Vol 43 (2): 184-201

Agricultural Research Council (ARC). 2008. ARC information resource. Available online: http://www.arc.agric.za: Downloaded in May 2008

Alcamo. J. 2001. Scenario as tools for international environmental assessments. European Environmental Agency. Environmental Issue report. No 24. Available online: www.usf.uos.de/IA/Scenarios.Report.pdf. Downloaded in March 2009

Ansoff. H.I. 1976. Managing surprise and discontinuity: strategic response to weak signals. Z. Betr. Wirtsch. Forsch. 28: 129-152

APEDA. 2008. Indian Trade Junction: Indian Trade Flow and Import Directory. Available online: http://www.apeda.com/tradejunction. Downloaded in April 2008

Benic. L. 2008. South African Table Grape Industry: Trade Access Matters. Unpublished report

BFAP. 2008. Outlook for South African table grape industry. Report prepared for SATI. Unpublished.

BFAP. 2009. BFAP Baseline Report. Available online: www.bfap.co.za. Downloaded in August 2009

BOABC. 2009. China Table Grape Industry Statistics. Available online: www. boabc.com. Downloaded in June 2009.

Bohensky. E., Reyers. B. and Van Jaarsveld. A. 2006. Scenario Planning Approach to uncertainty. Conservation Biology: 20(4). Pg: 1051-1062

Bood. R.P. and Postma. J.B.M. 2008. Scenario analysis as strategic management tool. Department of Management and Organisation, Faculty of Economics, University of Groningen. Available online :www.ecsocman.edu.ru/images/pubs/2008/05/28: downloaded in March 2009 
Bunn. D.W. and Salo. A.A. 1993. Forecasting with scenarios. European Journal of Operational research.

68: 291-303

Burger. H.J. 2001. An overview of table grape industry of South Africa, its position in the world market and the challenges facing the industry: MSc Agric Seminar: University of Stellenbosch

Burger. H.J. 2002. Comparative analysis of four early white seedless table grape cultivars in the Orange River Area. MSc Agric Thesis. University of Stellenbosch Printers.

Bradfield. R. 2005. Scenarios: Some lessons from the Research literature. University of Strathclyde: Graduate School of Business. Paper No: 2005 -09. Pg: 1-16

Capespan. 2008. Export table grapes: Guidelines for preparing table grapes. Capespan Exports. Bellville: South Africa

Chatterjee. K and Gordon. A. 2005. Planning for an unpredictable future. Transport in Great Britain in 2030. Centre for Transport \& Society. University of the West of England. Bristol B516 1Qy. UK

Cole. M.A. 1999. Limits to Growth. Sustainable Development and Environmental KUZNETS Curves. Sustainable Development. Vol 7: 87-97

Csaki. C. 1976. Simulation and system analysis in agriculture. Jointly published by Elsevier Science Publishers: Amsterdam, The Netherlands, and Akademiai Kiado, The Publishing house of the Hungarian Academy of Science: Budapest, Hungary

Decofruit. 2008. Table Grape Statistic from Chile. Available online: www.fruitonline.com. Downloaded in August 2008.

DFPT. 2008. Promotional Campaign for Plums in EU. Unpublished report

Encyclopedia.com. 2008. Indian Consumption Trends. Available online: http:www.encyclopedia.com.Downloaded in August 2008

Esterhuizen. D. 2006. An Evaluation of the Competitiveness of the South African Agribusiness Sector. PHD Thesis. University of Pretoria. Pretoria. 
Eurostats. 2007. Table Grape Statistics and Data from European countries. Available online: http://www.epp.eurostat.ec.europa.eu. Downloaded in June 2008.

Food and Agricultural Organization (FAO). 2008. Global Trade Flow. Available online: http://www.fao.org. Downloaded in April 2008.

Frudata. 2008. Table Grape Price Growth and Production Costs Trends: 1997-2008. Unpublished report

Fundira. T. 2003. A transactional costs analysis of the fruit supply chain in South Africa.: a case study approach. MSc Thesis. Stellenbosch University. Stellenbosch

Global Insight. 2008. Global Trade Flow and World Economic Indicators. Available online: www.globalinsight.com. Downloaded in March 2008.

Godet. M. 1982. From Forecasting to La Prospective: A new way of looking at futures. Journal of Forecasting. 1, 3: 293-301.

Gordon. T.J. and Hayward. H. 1968. Initial Experiments with the Cross Impact Matrix Method of Forecasting. Futures. 1(2)

Grayson. L.E. 1987. Who and how in planning for large companies. Basingstike: ackMillan.

Hooley. G.J. 1984. The implementation of strategic marketing planning techniques in British Industry. International Journal of Research in Marketing. 1: 153-162

Huss. W.R. 1988. A move towards scenario analysis. International Journal of Forecasting. 4: $377-388$

Institute for Global Dialogue. 2002. South Africa 2020: Five Scenarios. Johannesburg.

Johnson. S.R. and Rausser. G.C. 1977. System analysis and simulation: A Survey of applications in agricultural and resource economics. University of Minnesota Press: Minneapolis, USA

Kahn. H. and Weiner. A.J. 1968. The year 2000: A framework for speculations on the next thirty three years. Marcmallan. New York.

Liebl. F. 2002. The anatomy of complex societal problems and its implications for OR, J. Oper. Res: 161-184 
Linneman. R.E. and Klein. H.E. 1983. The use of multiple scenarios by US industrial companies: A comparison study. 1977-1981. Long Range Planning. 16(6): 94-101

Louw. A. 1979. Growth strategy for farm businesses. D.Sc (Agric), University of Pretoria: South Africa

Malaska. P. 1985. Multiple scenario approach and strategic behaviour in European companies. Strategic management Journal. 6: 339-355

Martellia. A, 1992. How Scenarios trigger strategic thinking. Long Range Plannning. 21 (5): 61-68

Mcknsey Global Institute (MGI). 2008. Global Outlook Statistics (Macroeconomic Indicators). Available online: www.mcknsey.com/mgi. Downloaded in September 2008.

Millett. S.M. 1988. How scenarios trigger strategic thinking. Long range Planning. 21:61-68

Mintzberg, H and Water, J. 1990. Of Strategies, deliberate and emergent. Strategic management Journal. Vol 6, 257-272

Mintzberg. H. 1994. The rise and Fall of Strategic Planning. Prentice Hall. Hemel Hempstead.

Msangi. S., Susler. T., Rosegrant. M., Valmonte-Santos. R. And Ringler. Claudia. 2007. Global Scenarios for Biofuel: Impacts and Implications. Report prepared for International Food policy Research Institute (IFPRI). Available online: www.globalbioenergy.org: Downloaded in March 2009

Nassauer. J.I., Santelmann. M. And Scavia. D. 2007. From the Corn Belt to the Gulf: Societal and Environmental Implications of Alternative Agricultural futures. Resources for the Future. Washington. DC.USA.

OECD. 2001. OECD Environmental Outlook to 2020. Available online: www.oecd.org/environment: Downloaded in March 2009

Optimal Agricultural Business Systems (OABS). 2005. Farm Assessment: Whole Farm Planning. Available Online: www.oabs.co.za. Downloaded in June 2009. 
Optimal Agricultural Business Systems (OABS). 2007. Fruit Industry Key Statistics. Available Online: www.oabs.co.za. Downloaded in June 2009.

Pesonen. H.L. et.al. 2000. Framework for Scenario Development in LCA. SETAC-Europe LCA Working Group. Available online: http://www.oikosstifting.unisg.ch/campus2000/article.pdf. Downloaded in May 2008.

Porter. M.E. 1985. Competitive advantage. The Free Press. New York.

Postma. T.J.B.M. and Liebl. F. 2005. How to improve scenario analysis as strategic management tool?. Technological forecasting \& Social Change. 72: $161-173$

Perishable Product Export Control Board (PPECB). 2009. Fruit Industry Statistics. Available online: www. ppecb.co.za. Downloaded in June 2009.

PricewaterCoopers. 2007. Global Retail and Consumer Study. Paper presented on Indian Fresh Produce Congress. Available online: www.freshproduceindia.com. Downloaded in June 2008

Proma International, 2001. Understanding the International Markets. Report prepared for NAMC. Unpublished.

Proma International, 2008. Opportunities in the BRIC Fresh Markets. Report prepared for SATI. Unpublished

Rabobank. 2007. Asian Consumer Profile. Paper presented on Indian Fresh Produce Congress. Available online: www.freshproduceindia.com. Downloaded in June 2008

Research Surveys. 2006. Project Red Dragon. Prepared for SATI. Available online: www.satgi.co.za. Downloaded in February 2008.

Richardson. J.W. 2003. Simulation for Applied Risk Management with an introduction to the excel Simulation Add-in: Simetar. Texas A\&M University: Colege Station, Texas

Ringland. G. 1998. Scenario Planning. John Wiley and Sons. Chichester Oxford.

Schwarts. P. 1991. The art of the long view: Planning for the future in an uncertain world. New York: Doubleday 
Schnaars. S.P. 1987. How to develop and use scenarios: Long Range Planning. 20:105-114

Schoemaker. P.J.H. 1993. Multiple scenario development: Its conceptual and behavioral foundation. Strategic Management Journal. 14: 193-213

Schoemaker. P.J.H. 1995. Scenario Planning: A tool for strategic thinking. Sloan Management Review. Winter

Schoemaker. P.J.H. and Van der Heijden. C.A.J.M. 1992. Integrating scenarios into strategic planning at Royal Dutch/Shell. Planning Review. 20 (3): 41-48

SHAFFE. 2008. Southern Hemisphere Table Grape Information. Available online: www.shaffe.net. Downloaded in October 2008

Stern. D.I. 2003. The Environmental Kuznets Curve. International Society for Ecological Economics. Available online: www.rpi.edu/ sternd/Riseandfall.pdf. Downloaded in September 2009

Strauss. P.G. 2005. Decision making in agriculture: A farm-level modeling approach. MSC (Agric). University of Pretoria: South Africa

South Africa Trade Information. 2008. Available online http://www.southafrica.info/business/trade/. Downloaded in September 2008.

SATI. 2008. The Strategic Planning report. South African Table Grape Industry, Paarl. Unpublished.

SATI. 2008a. Industry Census Report. South African Table Grape Industry, Paarl. Unpublished

SATI. 2009. Industry Statistics. South African Table Grape Industry, Paarl Available online: www.satgi.co.za. Downloaded in May 2009

Sparrow. G. 2000. Contemporary Use of Scenarios. Strategic Management Journal. Vol.6. pg: 187-206

Tenaglia. M. and Noonan. P. 1992. Scenario based strategic planning: A process for building top-management consensus. Planning Review. 20 (3): 12-19 
The Trade Matrix (TTM). 2005. Market Diversification Matrix Development. Report Prepared for SATI. Unpublished.

Tregurtha. N. and Vink. N. 2002. B2B E-commerce and the South African Horticultural Export Industry: current status and future directions. Univiresity of Stellenbosch. Stellenbosch

The SCS Group. 2007. India The Market of Contrast. Paper presented on India Fresh Produce Congress. Available online: www.freshproduceindia.com. Downloaded in June 2008.

United Nations Population Division. 2006. Global Population Statistics and Prospects Available online: http://www.un.org/esa/population/unpop.htm. Downloaded in March 2008.

United Nations Commodity Trade (UN Comtrade). 2007. Global Trade Statistics. Available Online: http://comtrade.un.org/db/default.aspx. Downloaded in May 2008

USDA, 2006. Agricultural Situation: Table Grape situation in the European Union. Available online: http://www.usda.gov. Downloaded on April 2008

USDA, 2008. The Worlds Markets and Trade. Avaliable online: http://www.usda.gov. Downloaded on August 2008

Van der Heijden. K. 1996. Scenarios: The art of strategic conversation. Wisley, New York

Van der Heijden. K. et. Al. 2002. The Sixth Sense Accelarating Organizational Learning with Scenario. Wiley and Sons. Chichester.

Van Zyl. J. 2007. Foresight Agriculture Report. Available online: www.dst.gov.za/publication-policies/foresight-report.doc. Downloaded in March 09

Van Zyl. J. Kirsten. J.F. Coestzee. G.K. and Blignaut. C.S. 1999. Finance and Farmers: A financial management guide for farmers. The Standard Bank Agricultural Division. Johannesburg

Vinpro. 2007. Farm Planning and profitability evaluation. Availableonline:www.vinpro.co.za. Downloaded in June 2008. 
Vinpro. 2008. Production Plan: Guide and Costs. Available online: www.vinpro.co.za. Downloaded in June 2008.

Von Notten. P.H.W.F. 2005. Writing on the Wall. Scenario Development in times of Discontinuity, Dissertation. Available online: www.dissertation.com. Downloaded on May 2008.

Von Reibnitz. U. 1988. Scenario Techniques. McGraw Hill. New York

Wack. P. 1985. Scenarios: Shooting the rapids. Harvaed Business Review. 63 (6): 139-150

Wikipedia. 2008. Scenario Development in Strategic literature. Available online: www.wikipedia.org/wiki/strategic_management. Downloaded in May 2008.

Wolfe. C. and Flores. B. E. 1990. Judgmental adjustment of earnings forecasts. Journal of Forecasting. 9(4): 389-405

World Economic Forum. 2008. Global Competitiveness Report. Available online: www.weforum.org.

Wright. G and Goodwin. P. 2009. Decision making and Planning under low level of predictability: Enhancing the scenario method. University of Durham, Mill-Hill lane. Durham City. DH! 313. UK

World Business Council for Sustainable Development (WBCSD), 2006. Business in the world of water: Water Scenario to 2025. Available online: www.wbcsd.org. Downloaded in June 2009

Zanoli. R., Gambelli. D. And Vairo. D. 2000. Organic Farming in Europe by 2010: Scenarios for the Future. ORGANIC FARMING IN Europe: Economic and Policy Volume 8 


\section{Annexure A}

\section{Western Cape Typical Farm Data}

\begin{tabular}{|ll}
\hline Table 1: Descriptions of the typical table grape farm in Western Cape \\
Farm Size & 46 \\
Hectares under Production & 39 \\
Management System: & Inorganic Farming \\
Trellising System: & All vines are grown on the trellising systems \\
Irrigation System: & All vines are irrigated \\
Grafting: & All vines are grafted \\
Bearing Capacity: 1 year & $0 \%$ \\
$: 2$ year & $35 \%$ \\
$: 3$ year & $70 \%$ \\
$: 4$ year & $100 \%$ \\
\hline
\end{tabular}

$\mid$\begin{tabular}{|ll} 
Table 2: Farm cultivar mix and their m \\
Variety group & Variety \\
White Seeded & Dauphine \\
& Victoria \\
White Seedless & Thompson Seedless \\
& Sugraone \\
Red Seeded & Red Globe \\
& Alpha Red \\
Red Seedless & Crimson Seedless \\
& Sunred Seedless \\
Black Seeded & La Rochelle \\
& Barlinka \\
Black Seedless & Midnight Beauty \\
& Autumn Royal \\
Market Demand A $=$ Very High
\end{tabular}

Market Demand and Popularity

EU Markets

East Markets

$\begin{array}{ll}\text { A } & \text { C } \\ \text { A } & \text { C }\end{array}$

C

A

Market Demand A = Very High

$B=$ Medium

$C=$ Low 


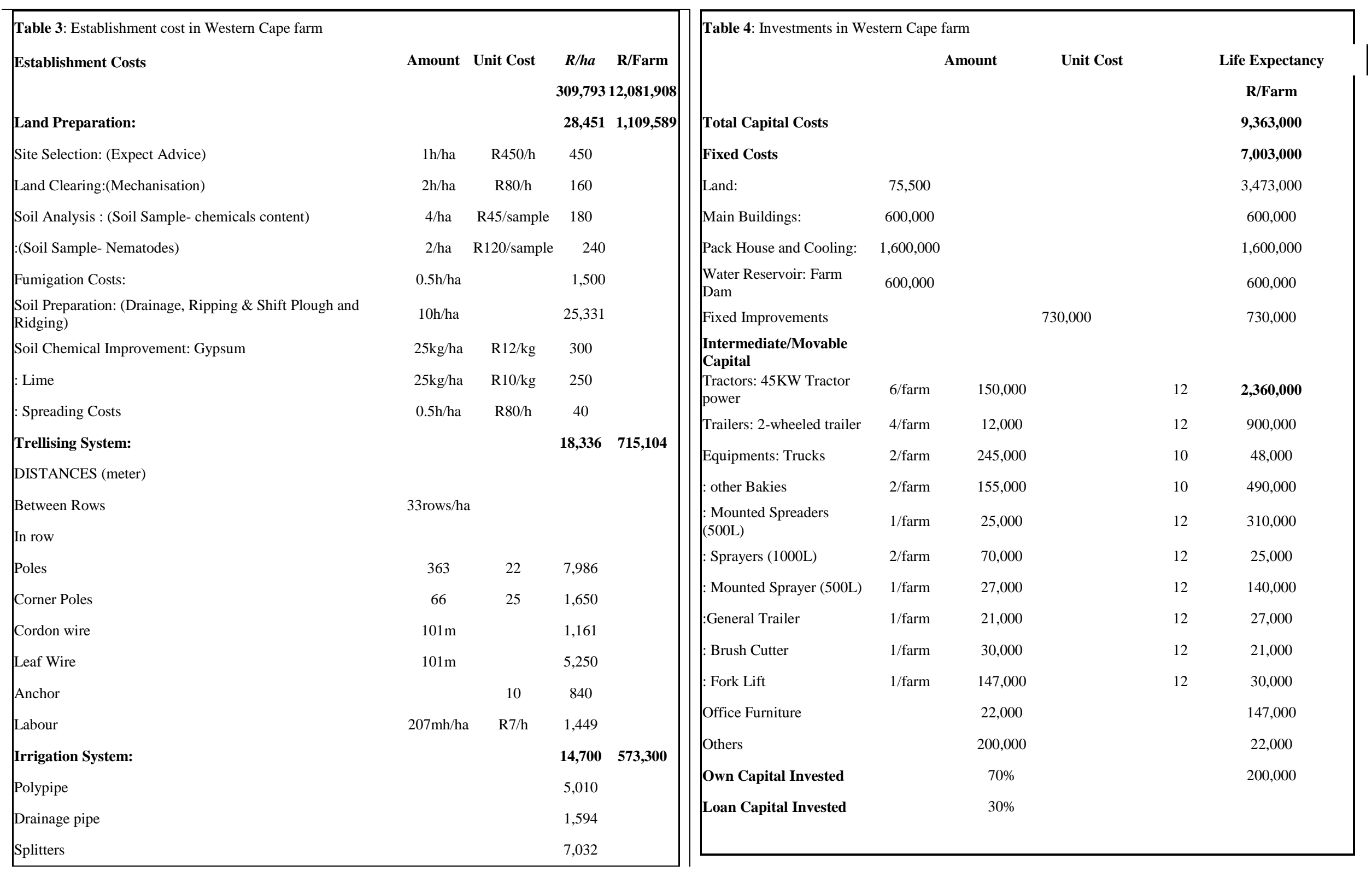




\begin{tabular}{|lccc||}
\hline Labour Costs & $152 \mathrm{mh}$ & $\mathrm{R} 7 / \mathrm{h}$ & 1,064 \\
Planting Material & & $\mathbf{2 4 8 , 3 0 6} \mathbf{9 , 6 8 3 , 9 1 5}$ \\
Labour Costs & $107 \mathrm{mh} / \mathrm{ha}$ & $\mathrm{R} 7 / \mathrm{h}$ & 750 \\
Cover Crop & & 11,250 \\
Dauphine & $1852 / \mathrm{ha}$ & 10.00 & 18,520 \\
Victoria & $1667 / \mathrm{ha}$ & 10.00 & 16,670 \\
Thompson Seedless & $1667 / \mathrm{ha}$ & 10.50 & 17,504 \\
Sugraone & $1852 / \mathrm{ha}$ & 10.50 & 19,446 \\
Red Globe & $1786 / \mathrm{ha}$ & 10.50 & 18,753 \\
Alpha Red & $1667 / \mathrm{ha}$ & 10.60 & 17,670 \\
Crimson Seedless & $1736 / \mathrm{ha}$ & 10.50 & 18,228 \\
Sunred Seedless & $1852 / \mathrm{ha}$ & 10.50 & 19,446 \\
La Rochelle & $2222 / \mathrm{ha}$ & 10.00 & 22,220 \\
Barlinka & $2222 / \mathrm{ha}$ & 10.00 & 22,220 \\
Midnight Beauty & $1852 / \mathrm{ha}$ & 11.20 & 20,742 \\
Autumn Royal & $2222 / \mathrm{ha}$ & 11.20 & 24,886 \\
& & & \\
\hline
\end{tabular}




\section{Annexure B}

\section{Northern Region Typical Farm Data}

\begin{tabular}{|c|c|}
\hline \multicolumn{2}{|c|}{ Table 1: Descriptions of the typical table grape farm in Northern region } \\
\hline Farm Size & 65 ha \\
\hline $\begin{array}{l}\text { Hectares under } \\
\text { Production }\end{array}$ & 57 ha \\
\hline Management System: & Inorganic Farming \\
\hline Trellising System: & All vines are grown on the trellising systems \\
\hline Irrigation System: & All vines are irrigated \\
\hline Grafting: & All vines are grafted \\
\hline Bearing Capacity: 1 year & $0 \%$ \\
\hline 2 year & $35 \%$ \\
\hline 3 year & $70 \%$ \\
\hline : 4 year & $100 \%$ \\
\hline
\end{tabular}

\begin{tabular}{llcl}
\hline Table 2: Farm cultivar mix and their market popularity & & \\
Variety group & Variety & EU Markets & Eastern Markets \\
White Seeded & Moonballs & B & C \\
White Seedless & Prime Seedless & A & A \\
Thompson Seedless & A & A \\
Red Seeded & Red Globe & A & A \\
Red Seedless & Flame Seedless & A & A \\
Black Seeded & Crimson Seedless & A & A \\
Black Seedless & Ronelle (Black Gem) & A & C \\
Market Demand & Midnight Beauty & A & A \\
\hline
\end{tabular}

\begin{tabular}{lcccc|}
\hline Table 3: Establishment costs in Northern region farm & & & & \\
& Amount & Unit Cost & R/ha & R/Farm \\
Establishment Costs & & & $\mathbf{2 5 5 , 8 6 4}$ & $\mathbf{1 4 , 5 8 4 , 2 5 4}$ \\
Land Preparation: & & & $\mathbf{3 5 , 6 5 1}$ & $\mathbf{2 , 0 3 2 , 1 0 7}$ \\
Site Selection: (Expect Advice) & $1 \mathrm{~h} / \mathrm{ha}$ & $\mathrm{R} 465 / \mathrm{h}$ & 465 \\
Land Clearing:(Mechanisation) & $2 \mathrm{~h} / \mathrm{ha}$ & $\mathrm{R} 90 / \mathrm{h}$ & 180 \\
Soil Analysis : (Soil Sample- chemicals content) & $4 / \mathrm{ha}$ & $\mathrm{R} 48 / \mathrm{sample}$ & 192 \\
:(Soil Sample- Nematodes) & $2 / \mathrm{ha}$ & $\mathrm{R} 125 / \mathrm{sample}$ & 250 \\
Fumigation Costs: & $0.5 \mathrm{~h} / \mathrm{ha}$ & & 1,600 \\
Soil Preparation: (Drainage, Ripping \& Shift Plough and & $10 \mathrm{~h} / \mathrm{ha}$ & & 32,324 \\
Ridging) & $25 \mathrm{~kg} / \mathrm{ha}$ & $\mathrm{R} 13 / \mathrm{kg}$ & 325 \\
Soil Chemical Improvement: Gypsum & $25 \mathrm{~kg} / \mathrm{ha}$ & $\mathrm{R} 11 / \mathrm{kg}$ & 275 \\
: Lime & $0.5 \mathrm{~h} / \mathrm{ha}$ & $\mathrm{R} 80 / \mathrm{h}$ & 40 \\
Spreading Costs & & & \\
\hline
\end{tabular}

\begin{tabular}{|c|c|c|c|c|}
\hline \multicolumn{5}{|c|}{ Table 4: Investments in Northern region farm } \\
\hline & Amount & Unit Cost & Life Expectancy & \\
\hline & & & & R/Farm \\
\hline Total Capital Costs & & & & $9,139,000$ \\
\hline Fixed Costs & & & & $6,590,000$ \\
\hline Land: & & 47,200 & & $3,068,000$ \\
\hline Main Buildings: & & 450,000 & & 450,000 \\
\hline Pack House and Cooling: & & $1,763,000$ & & $1,763,000$ \\
\hline Water Reservoir: Farm Dam & & 489,000 & & 489,000 \\
\hline Fixed Improvements & & 820,000 & & 820,000 \\
\hline Intermediate/Movable Capital & & & & $2,549,000$ \\
\hline Tractors: $45 \mathrm{KW}$ Tractor power & $7 /$ farm & 150,000 & 12 & $1,050,000$ \\
\hline
\end{tabular}




\begin{tabular}{|c|c|c|c|c|c|c|c|c|c|c|}
\hline Trellising System: & & & 32,806 & $1,869,942$ & Trailers: 2 -wheeled trailer & $5 /$ farm & 12,000 & & 12 & 60,000 \\
\hline DISTANCES (meter) & & & & & Equipments: Trucks & $2 /$ farm & 245,000 & & 10 & 490,000 \\
\hline Between Rows & 33rows/ha & & & & : other Bakies & $2 /$ farm & 155,000 & & 10 & 310,000 \\
\hline In row & & & & & Mounted Spreaders (500L) & $1 /$ farm & 25,000 & & 12 & 25,000 \\
\hline Poles & 363 & 22 & 7,986 & & Spravers (1000L) & 2/farm & 70,000 & & 12 & 140,000 \\
\hline Corner Poles & 66 & 25 & 1,650 & & Splaycis (I000L) & & & & & \\
\hline Cordon wire & $101 \mathrm{~m}$ & & 1,161 & & : Mounted Sprayer (500L) & $2 /$ farm & 27,000 & & 12 & 54,000 \\
\hline Leaf Wire & $101 \mathrm{~m}$ & & 5,250 & & :General Trailer & $1 /$ farm & 21,000 & & 12 & 21,000 \\
\hline Anchor & & 10 & 840 & & Brush Cutter & $1 /$ farm & 30,000 & & 12 & 30,000 \\
\hline Nets/Plastics & & & 14,470 & & : Fork Lift & $1 /$ farm & 147,000 & & 12 & 147,000 \\
\hline Labour & $207 \mathrm{mh} / \mathrm{ha}$ & $\mathrm{R} 7 / \mathrm{h}$ & 1,449 & & Office Furniture & & 22,000 & & & 22,000 \\
\hline Irrigation System: & & & 14,721 & 839,097 & Others & & 200,000 & & & 200,000 \\
\hline Polypipe & & & 5,010 & & Own Canital Invested & $\%$ & & $70 \%$ & & \\
\hline Drainage pipe & & & 1,594 & & Own Captan mosted & & & & & \\
\hline Splitters & & & 7,032 & & Loan Capital Invested & $\%$ & & $30 \%$ & & \\
\hline Labour Costs & $155 \mathrm{mh}$ & $\mathrm{R} 7 / \mathrm{h}$ & 1,085 & & & & & & & \\
\hline Planting Material & & & 172,686 & $9,843,108$ & & & & & & \\
\hline Labour Costs & $107 \mathrm{mh} / \mathrm{ha}$ & $\mathrm{R} 7 / \mathrm{h}$ & 750 & & & & & & & \\
\hline Cover Crop & & & 11,250 & & & & & & & \\
\hline Moonballs & 1852/ha & 11.20 & 20,742 & & & & & & & \\
\hline Prime Seedless & 1667/ha & 11.00 & 18,337 & & & & & & & \\
\hline Thompson Seedless & 1667/ha & 11.50 & 19,171 & & & & & & & \\
\hline Red Globe & $1852 / \mathrm{ha}$ & 11.50 & 21,298 & & & & & & & \\
\hline Flame Seedless & 1786/ha & 11.50 & 20,539 & & & & & & & \\
\hline Crimson Seedless & $1667 / \mathrm{ha}$ & 11.60 & 19,337 & & & & & & & \\
\hline Ronelle (Black Gem) & $1736 / \mathrm{ha}$ & 11.50 & 19,964 & & & & & & & \\
\hline
\end{tabular}




\section{Annexure C}

\section{Farm-level model structure and results of Western Cape farm under Scenario 1}

\begin{tabular}{|c|c|c|c|c|c|c|c|c|c|c|c|c|c|c|c|c|c|c|c|c|c|}
\hline $\begin{array}{l}\text { Years } \\
\text { Corresponding year }\end{array}$ & & $\begin{array}{c}1 \\
2007\end{array}$ & $\begin{array}{c}2 \\
2008\end{array}$ & $\begin{array}{c}3 \\
2009\end{array}$ & $\begin{array}{c}4 \\
2010\end{array}$ & $\begin{array}{c}5 \\
2011\end{array}$ & $\begin{array}{c}6 \\
2012\end{array}$ & 2013 & $\begin{array}{c}8 \\
2014\end{array}$ & $\begin{array}{c}9 \\
2015\end{array}$ & $\begin{array}{c}10 \\
2016\end{array}$ & $\begin{array}{c}11 \\
2017\end{array}$ & $\begin{array}{c}12 \\
2018\end{array}$ & $\begin{array}{c}13 \\
2019\end{array}$ & $\begin{array}{c}14 \\
2020\end{array}$ & $\begin{array}{c}15 \\
2021\end{array}$ & $\begin{array}{c}16 \\
2022\end{array}$ & $\begin{array}{c}17 \\
2023\end{array}$ & $\begin{array}{c}18 \\
2024\end{array}$ & $\begin{array}{c}19 \\
2025\end{array}$ & $\begin{array}{c}20 \\
2026\end{array}$ \\
\hline Cultivar Margin & На & & & & & & & & & & & & & & & & & & & & \\
\hline Dauphine & 4.26 & $-455,876$ & 265,326 & 493,445 & 706,677 & 713,029 & 715,218 & 751,237 & 785,462 & 805,453 & 807,470 & 802,861 & 807,589 & 813,839 & 821,254 & 824,282 & 830,473 & 845,778 & 838,879 & 848,822 & 848,159 \\
\hline Victoria & 1.06 & $-112,001$ & 105,685 & 164,963 & 224,609 & 227,644 & 231,681 & 229,471 & 231,558 & 229,789 & 231,123 & 230,141 & 232,238 & 234,226 & 235,484 & 238,220 & 239,704 & 239,955 & 243,763 & 245,781 & 242,806 \\
\hline Thompson Seedless & 7.94 & $-842,625$ & 454,356 & 683,507 & $1,005,922$ & $1,019,840$ & $1,004,706$ & $1,003,301$ & $1,018,085$ & $1,009,644$ & $1,073,608$ & $1,069,455$ & $1,064,458$ & $1,052,296$ & $1,054,537$ & $1,074,959$ & $1,084,448$ & $1,070,439$ & $1,067,889$ & $1,063,888$ & $1,099,660$ \\
\hline Sugraone & 6.50 & $-702,043$ & 447,571 & $1,127,990$ & $1,524,421$ & $1,442,237$ & $1,461,176$ & $1,481,680$ & $1,503,178$ & $1,524,630$ & $1,546,314$ & $1,567,641$ & $1,589,084$ & $1,610,685$ & $1,631,913$ & $1,653,277$ & $1,674,366$ & $1,695,315$ & $1,716,151$ & $1,736,725$ & $1,756,997$ \\
\hline Red Globe & 3.23 & $-346,730$ & 232,290 & 313,976 & 471,510 & 473,134 & 484,279 & 496,436 & 509,331 & 522,458 & 535,967 & 549,577 & 563,535 & 577,876 & 592,347 & 607,217 & 622,294 & 637,661 & 653,345 & 669,290 & 685,491 \\
\hline Alpha Red & 0.57 & $-60,570$ & 23,488 & 37,018 & 52,405 & 53,689 & 53,882 & 54,184 & 54,543 & 54,867 & 55,180 & 55,430 & 55,658 & 55,867 & 56,010 & 56,130 & 56,190 & 56,203 & 56,169 & 56,075 & 55,917 \\
\hline Crimson Seedless & 6.12 & $-653,536$ & 591,631 & $1,214,058$ & $1,741,173$ & $1,761,684$ & $1,784,899$ & $1,784,428$ & $1,808,664$ & $1,822,963$ & $1,848,988$ & $1,846,401$ & $1,858,459$ & $1,863,773$ & $1,877,124$ & $1,886,737$ & $1,913,624$ & $1,930,364$ & $1,955,319$ & $1,939,389$ & $1,968,169$ \\
\hline Sunred Seedless & 2.62 & $-283,280$ & 242,470 & 506,031 & 709,299 & 711,010 & 729,917 & 749,942 & 770,870 & 792,300 & 814,365 & 836,843 & 859,947 & 883,715 & 907,953 & 932,889 & 958,379 & 984,501 & $1,011,292$ & $1,038,715$ & $51,066,780$ \\
\hline La Rochelle & 2.07 & $-228,875$ & 144,638 & 209,586 & 303,276 & 318,193 & 325,798 & 334,064 & 342,816 & 351,732 & 360,908 & 370,165 & 379,661 & 389,418 & 399,277 & 409,409 & 419,692 & 430,179 & 440,890 & 451,787 & 462,869 \\
\hline Barlinka & 2.87 & $-318,545$ & 144,734 & 203,931 & 321,548 & 327,736 & 334,826 & 342,732 & 351,207 & 359,799 & 368,638 & 377,472 & 386,517 & 395,800 & 405,096 & 414,639 & 424,256 & 434,016 & 443,942 & 453,979 & 464,118 \\
\hline Midnight Beauty & 1.00 & $-85,282$ & 78,663 & 135,863 & 203,101 & 204,312 & 205,478 & 207,072 & 207,057 & 207,929 & 209,390 & 211,697 & 212,282 & 214,754 & 213,804 & 215,389 & 214,542 & 216,520 & 214,772 & 219,106 & 219,359 \\
\hline \multirow[t]{2}{*}{ Autumn Royal } & 1.00 & $-88,515$ & 73,847 & 127,149 & 196,877 & 197,105 & 200,892 & 200,520 & 202,143 & 201,704 & 202,511 & 201,541 & 211,300 & 204,271 & 205,614 & 206,216 & 207,007 & 205,382 & 207,893 & 209,278 & 211,824 \\
\hline & 39.24 & & & & & & & & & & & & & & & & & & & & \\
\hline $\begin{array}{l}\text { Total Farm Gross } \\
\text { Margin }\end{array}$ & & $-4,177,878$ & $2,804,700$ & $5,217,518$ & $7, \mathbf{4 6 0 , 8 1 9}$ & $7,449,614$ & $7,532,751$ & $7,635,067$ & 7,784,915 & $7,883,267$ & $8,054,462$ & $8,119,226$ & $8,220,728$ & $8,296,520$ & $8,400,414$ & $8,519,362$ & $8,644,977$ & $8,746,314$ & $\mathbf{8 , 8 5 0 , 3 0 6}$ & $8,932,835$ & $9,082,150$ \\
\hline $\begin{array}{l}\text { Indirectly Allocatable } \\
\text { Costs/Farm }\end{array}$ & & 2,958,579 & $3,069,105$ & $3,156,798$ & $3,249,307$ & $3,376,465$ & $3,501,665$ & $3,722,993$ & $3,959,940$ & $4,211,051$ & $4,476,641$ & $4,766,604$ & $5,074,918$ & $5,407,026$ & $5,758,716$ & $6,136,602$ & $6,300,854$ & $6,480,461$ & $6,667,428$ & $6,858,678$ & ; 7,055,936 \\
\hline $\begin{array}{l}\text { Indirectly Allocatable } \\
\text { Costs/Ha }\end{array}$ & & 75,861 & 78,695 & 80,944 & 83,316 & 86,576 & 89,786 & 95,461 & 101,537 & 107,976 & 114,786 & 122,221 & 130,126 & 138,642 & 147,659 & 157,349 & 161,560 & 166,166 & 170,960 & 175,864 & 180,921 \\
\hline Labour & & 56,606 & 58,321 & 60,071 & 61,873 & 63,729 & 65,641 & 69,579 & 73,754 & 78,179 & 82,870 & 87,842 & 93,113 & 98,699 & 104,621 & 110,899 & 114,226 & 117,652 & 121,182 & 124,818 & 128,562 \\
\hline Electricity & & 2,652 & 3,012 & 3,212 & 3,345 & 3,487 & 3,567 & 3,789 & 3,876 & 3,899 & 4,012 & 4,123 & 4,234 & 4,378 & 4,388 & 4,412 & 4,197 & 4,204 & 4,265 & 4,331 & 4,378 \\
\hline Water & & 483 & 512 & 523 & 538 & 578 & 610 & 622 & 621 & 632 & 639 & 642 & 646 & 649 & 712 & 725 & 738 & 745 & 748 & 755 & 761 \\
\hline License and assurances & & 1,201 & 1,205 & 1,219 & 1,223 & 1,227 & 1,229 & 1,231 & 1,234 & 1,235 & 1,236 & 1,238 & 1,240 & 1,243 & 1,245 & 1,246 & 1,249 & 1,250 & 1,254 & 1,255 & 1,257 \\
\hline Administration & & 2,646 & 2,667 & 2,687 & 2,711 & 2,732 & 2,736 & 2,739 & 2,821 & 2,832 & 2,823 & 2,833 & 2,838 & 2,846 & 2,854 & 2,891 & 2,899 & 2,901 & 2,921 & 2,927 & 2,928 \\
\hline General Costs & & 421 & 432 & 435 & 445 & 456 & 487 & 433 & 456 & 546 & 488 & 553 & 567 & 589 & 578 & 589 & 567 & 598 & 610 & 599 & 621 \\
\hline Fuel and Energy & & 11,852 & 12,546 & 12,797 & 13,181 & 14,367 & 15,516 & 17,068 & 18,775 & 20,652 & 22,718 & 24,989 & 27,488 & 30,237 & 33,261 & 36,587 & 37,685 & 38,815 & 39,980 & 41,179 & 42,414 \\
\hline $\begin{array}{l}\text { Margin before Capital } \\
\text { Expenditure }\end{array}$ & & $-7,136,457$ & $-264,405$ & $2,060,719$ & $4,211,511$ & $4,073,149$ & $4,031,087$ & $3,912,074$ & $3,824,974$ & $3,672,216$ & $3,577,821$ & $3,352,621$ & $3,145,811$ & $2,889,493$ & $2,641,698$ & $2,382,760$ & $2,344,123$ & $2,265,853$ & $2,182,878$ & 2,074,157 & 2,026,214 \\
\hline \multicolumn{22}{|l|}{ Farm Capital } \\
\hline Fixed Costs/farm & & $5,403,000$ & $1,600,000$ & 0.00 & 0.00 & 0.00 & 0.00 & 0.00 & 0.00 & 0.00 & 0.00 & 0.00 & 0.00 & 0.00 & 0.00 & 0.00 & 0.00 & 0.00 & 0.00 & 0.00 & 0.00 \\
\hline $\begin{array}{l}\text { Land: } \\
\text { Main Buildings: }\end{array}$ & & $\begin{array}{c}3,473,000 \\
600,000\end{array}$ & & & & & & & & & & & & & & & & & & & \\
\hline Pack House and Cooling: & & & $1,600,000$ & & & & & & & & & & & & & & & & & & \\
\hline $\begin{array}{l}\text { Water Reservoir: Farm } \\
\text { Dam }\end{array}$ & & 600,000 & & & & & & & & & & & & & & & & & & & \\
\hline Fixed Improvements & & 730,000 & & & & & & & & & & & & & & & & & & & \\
\hline $\begin{array}{l}\text { Capital/farm } \\
\text { Covabere }\end{array}$ & & 990,000 & 421,000 & 238,000 & 285,000 & 337,000 & 40,000 & 40,000 & 0.00 & 0.00 & 0.00 & 0.00 & 0.00 & 0.00 & 0.00 & 0.00 & 0.00 & 0.00 & 0.00 & 0.00 & 0.00 \\
\hline Tractors: 45KW Tractor & & 297,000 & 297,000 & & & 297,000 & & & & & & & & & & & & & & & \\
\hline
\end{tabular}




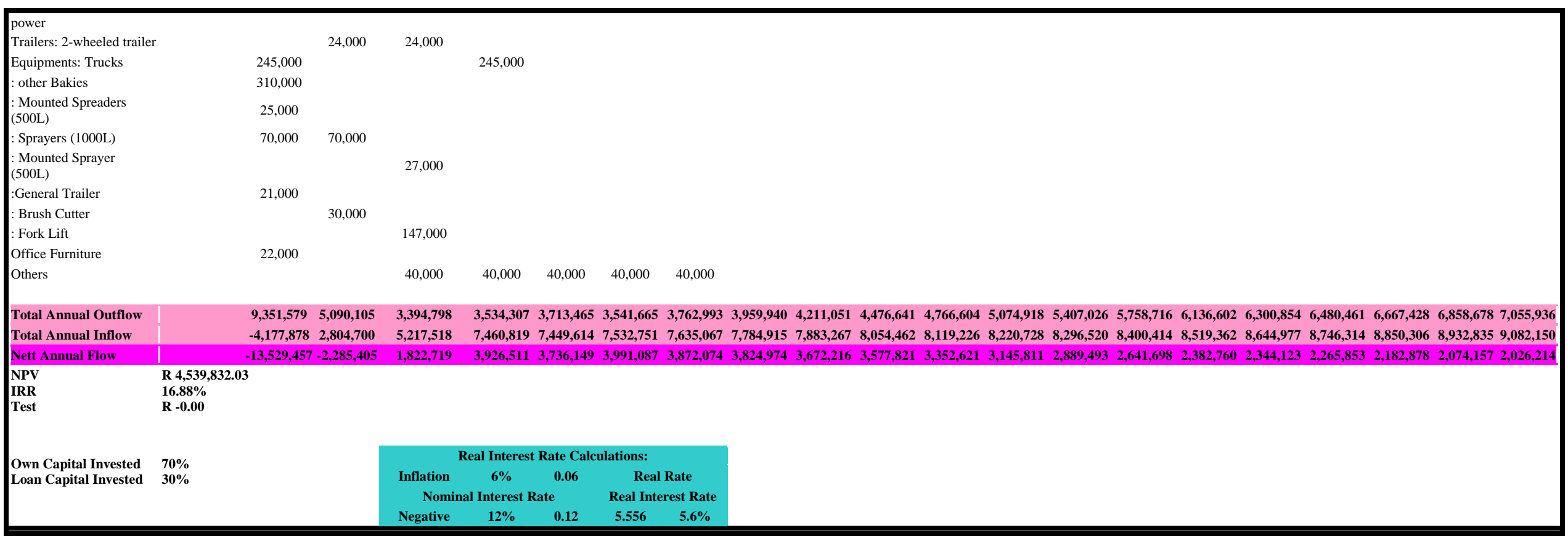




\section{Annexure D}

\section{Farm-level model structure and results of Northern Region farm under Scenario 1}

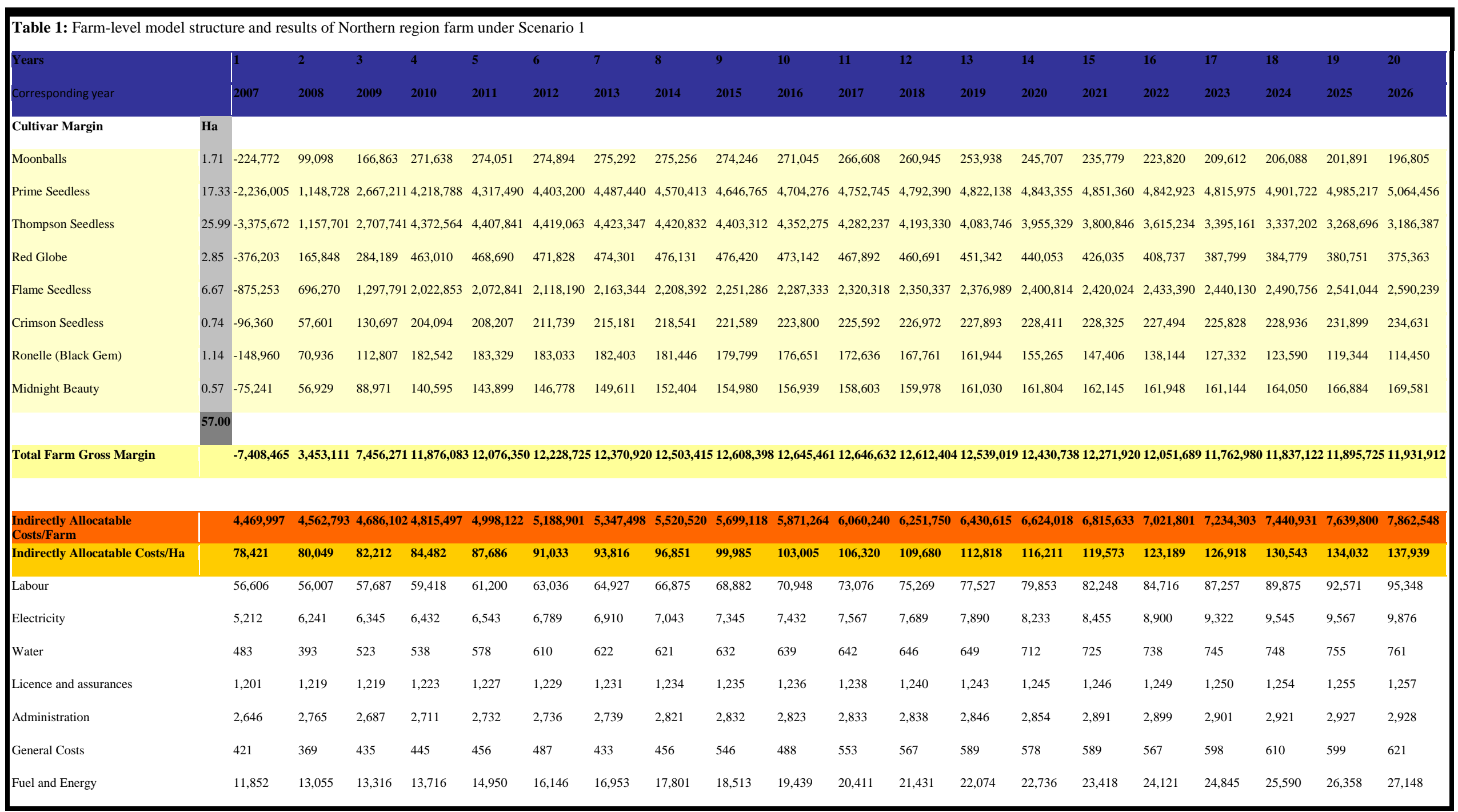




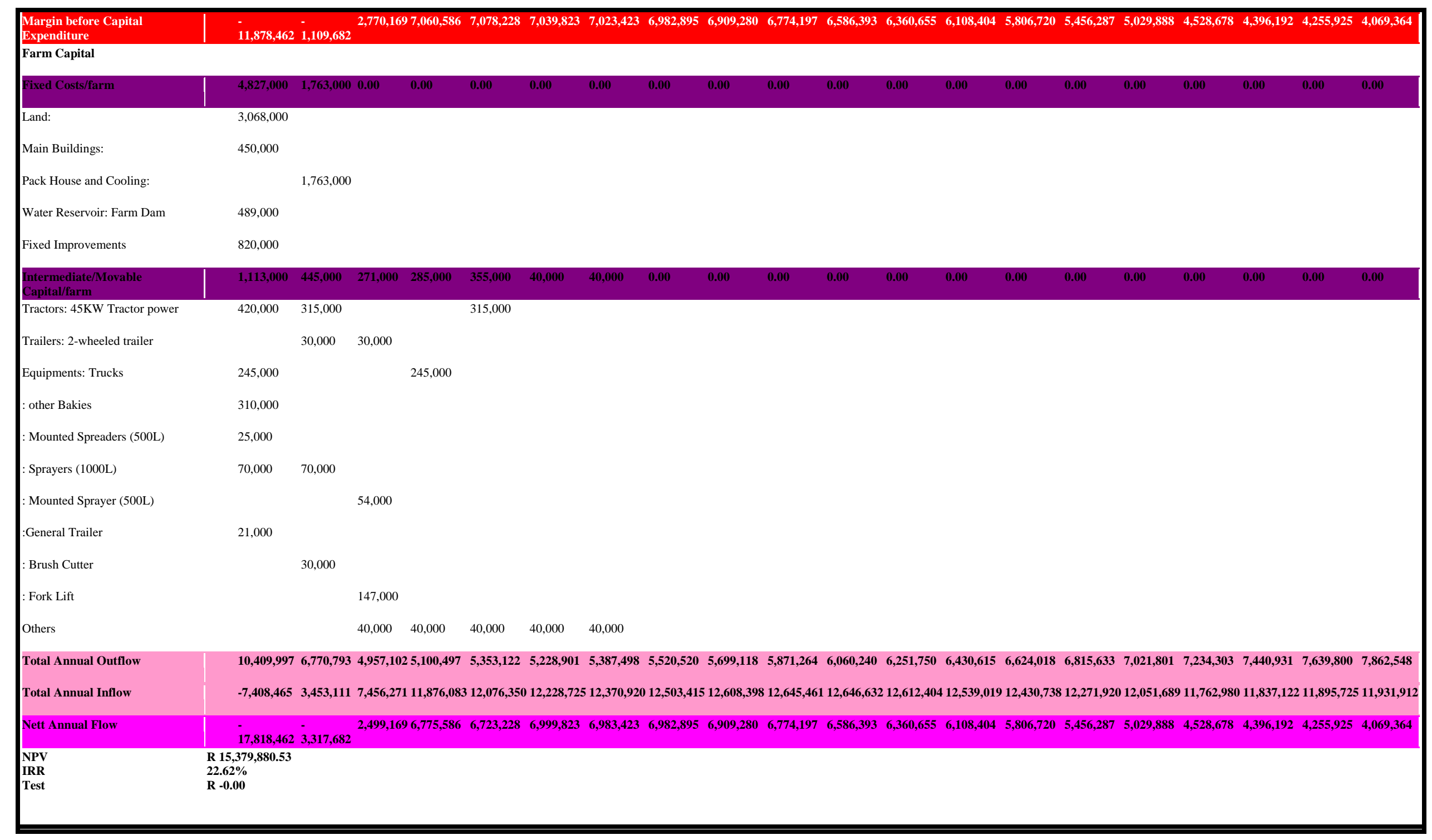


Annexure E

Farm-level model structure and results of Western Cape farm under Scenario 2A

\begin{tabular}{|c|c|c|c|c|c|c|c|c|c|c|c|c|c|c|c|c|c|c|c|c|c|}
\hline Years & & 1 & 2 & 3 & 4 & 5 & 6 & 7 & 8 & 9 & 10 & 11 & 12 & 13 & 14 & 15 & 16 & $17 \quad \mid$ & 18 & 19 & 20 \\
\hline Corresponding years & & 2007 & 2008 & 2009 & 2010 & 2011 & 2012 & 2013 & 2014 & 2015 & 2016 & 2017 & 2018 & 2019 & 2020 & 2021 & 2022 & $2023 \mid$ & 2024 & 2025 & 2026 \\
\hline Cultivar Margin & На & & & & & & & & & & & & & & & & & & & & \\
\hline Dauphine & 2.73 & $-455,876$ & 265,326 & 552,675 & 801,911 & 811,460 & 821,178 & 533,600 & 540,839 & 548,023 & 555,269 & 562,327 & 569,396 & 576,492 & 583,392 & 590,309 & 597,069 & 603,728 & 610,297 & 616,712 & 622,956 \\
\hline Victoria & 1.17 & $-112,001$ & 105,685 & 218,454 & 317,471 & 322,204 & 327,025 & 332,138 & 341,455 & 351,000 & 342,726 & 362,878 & 419,124 & 430,780 & 442,678 & 449,501 & 456,335 & 463,204 & 470,115 & 477,041 & 483,978 \\
\hline Thompson Seedless & 6.32 & $-850,698$ & 499,671 & 756,1241 & $1,095,374$ & $1,105,140$ & $1,115,062$ & $1,126,6331$ & $1,155,488$ & 942,551 & 966,569 & 990,712 & $1,015,461$ & $1,040,881$ & $1,066,479$ & $1,076,789$ & $1,086,622$ & $1,096,104$ & $1,105,260$ & $1,113,938$ & $1,122,097$ \\
\hline Sugraone & 7.72 & $-696,025$ & 447,571 & 952,8691 & $1,391,862$ & $1,233,725$ & $1,370,507$ & $1,753,4741$ & $1,823,8811$ & $1,896,929$ & $1,973,078$ & $2,051,756$ & $2,133,663$ & $2,218,993$ & $2,307,264$ & $2,428,847$ & $2,556,468$ & $2,690,637$ & $2,831,755$ & $2,980,031$ & $3,135,823$ \\
\hline Red Globe & 3.12 & $-346,730$ & 232,290 & 313,976 & 458,029 & 465,456 & 473,095 & 481,560 & 500,891 & 520,923 & 541,831 & 563,359 & 585,783 & 609,164 & 633,284 & 653,513 & 697,908 & 745,146 & 795,433 & 848,900 & 905,746 \\
\hline Alpha Red & 0.00 & $-60,570$ & 23,488 & 37,018 & 53,474 & 53,666 & 53,859 & 54,160 & 54,519 & 54,842 & 55,155 & 0.00 & 0.00 & 0.00 & 0.00 & 0.00 & 0.00 & 0.00 & 0.00 & 0.00 & 0.00 \\
\hline Crimson Seedless & 9.67 & $-653,536$ & 634,0541 & $1,300,0611$ & $1,900,480$ & $1,940,452$ & $1,981,472$ & 2,024,719 & $1,631,7802$ & $2,200,184$ & $4,252,521$ & $4,670,068$ & $5,126,710$ & $5,626,098$ & $6,171,354$ & $6,557,730$ & $6,967,570$ & $7,402,558$ & $7,864,311$ & $8,354,275$ & $8,874,162$ \\
\hline Sunred Seedless & 2.42 & $-283,280$ & 242,470 & 506,031 & 735,286 & 746,025 & 698,071 & 708,804 & 737,272 & 766,824 & 797,614 & 829,474 & 862,633 & 897,165 & 932,931 & 992,950 & $1,056,640$ & $1,124,291$ & $1,196,167$ & $1,272,483$ & $1,353,509$ \\
\hline La Rochelle & 1.76 & $-228,875$ & 144,638 & 217,740 & 315,624 & 318,790 & 322,009 & 325,669 & 329,589 & 333,435 & 337,296 & 340,982 & 344,644 & 295,949 & 298,894 & 301,820 & 304,615 & 307,314 & 309,923 & 312,401 & 314,736 \\
\hline Barlinka & 1.76 & $-318,545$ & 144,734 & 203,931 & 321,548 & 200,089 & 204,418 & 206,128 & 208,030 & 209,842 & 211,637 & 213,254 & 214,819 & 216,342 & 217,679 & 218,965 & 220,086 & 221,078 & 221,947 & 222,649 & 223,173 \\
\hline Midnight Beauty & 1.17 & $-85,282$ & 89,780 & 163,578 & 181,824 & 210,860 & 353,052 & 362,789 & 399,223 & 439,058 & 482,661 & 530,271 & 582,349 & 639,314 & 701,517 & 729,520 & 758,597 & 788,820 & 820,244 & 852,895 & 886,819 \\
\hline Autumn Royal & 1.17 & $-88,515$ & 84,391 & 92,421 & 192,141 & 348,941 & 345,353 & 354,859 & 390,580 & 429,637 & 472,392 & 519,078 & 570,149 & 626,015 & 687,021 & 698,727 & 710,541 & 755,194 & 785,273 & 816,525 & 848,995 \\
\hline Total Farm Gross Margin & & $-4,179,934$ & $2,914,0985$ & 5,314,879 7 & 7,765,024 & 7,756,808 & $8,065,101$ & $8,264,5358$ & $8,113,5478$ & $8,693,247$ & $10,988,748$ & $11,634,1591$ & 12,424,731 & $13,177,195$ & $14,042,4941$ & $14,698,670$ & $15,412,450$ & $16,198,074$ & $17,010,724$ & $17,867,851$ & $18,771,993$ \\
\hline Indirectly Allocatable Costs/Farm & & $2,958,579$ & $3,069,1053$ & $3,156,7983$ & $3,249,307$ & $3,376,465$ & $3,501,665$ & 3,722,993 & $3,959,9404$ & $4,211,051$ & $4,476,641$ & $4,766,604$ & $5,074,918$ & $5,407,026$ & $5,758,716$ & $6,136,602$ & $6,300,854$ & $6,480,461$ & $6,667,428$ & $6,858,678$ & $7,055,936$ \\
\hline Indirectly Allocatable Costs/Ha & & 75,861 & 78,695 & 80,944 & 83,316 & 86,576 & 89,786 & 95,461 & 101,537 & 107,976 & 114,786 & 122,221 & 130,126 & 138,642 & 147,659 & 157,349 & 161,560 & 166,166 & 170,960 & 175,864 & 180,921 \\
\hline Labour & & 56,606 & 58,321 & 60,071 & 61,873 & 63,729 & 65,641 & 69,579 & 73,754 & 78,179 & 82,870 & 87,842 & 93,113 & 98,699 & 104,621 & 110,899 & 114,226 & 117,652 & 121,182 & 124,818 & 128,562 \\
\hline Electricity & & 2,652 & 3,012 & 3,212 & 3,345 & 3,487 & 3,567 & 3,789 & 3,876 & 3,899 & 4,012 & 4,123 & 4,234 & 4,378 & 4,388 & 4,412 & 4,197 & 4,204 & 4,265 & 4,331 & 4,378 \\
\hline Water & & 483 & 512 & 523 & 538 & 578 & 610 & 622 & 621 & 632 & 639 & 642 & 646 & 649 & 712 & 725 & 738 & 745 & 748 & 755 & 761 \\
\hline Licence and assurances & & 1,201 & 1,205 & 1,219 & 1,223 & 1,227 & 1,229 & 1,231 & 1,234 & 1,235 & 1,236 & 1,238 & 1,240 & 1,243 & 1,245 & 1,246 & 1,249 & 1,250 & 1,254 & 1,255 & 1,257 \\
\hline
\end{tabular}




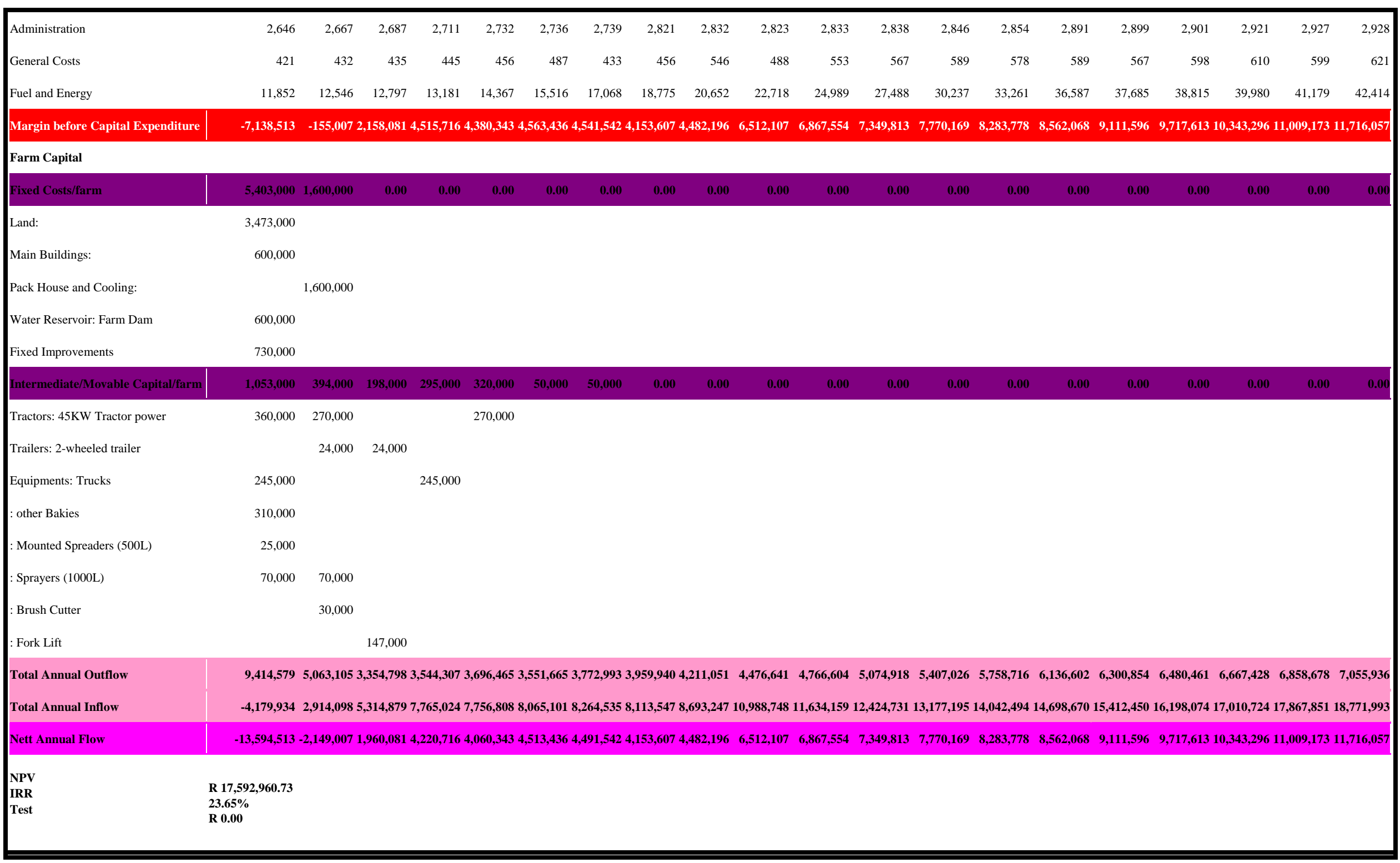




\section{Annexure F}

\section{Farm-level model structure and results of Northern Region farm under Scenario 2A}

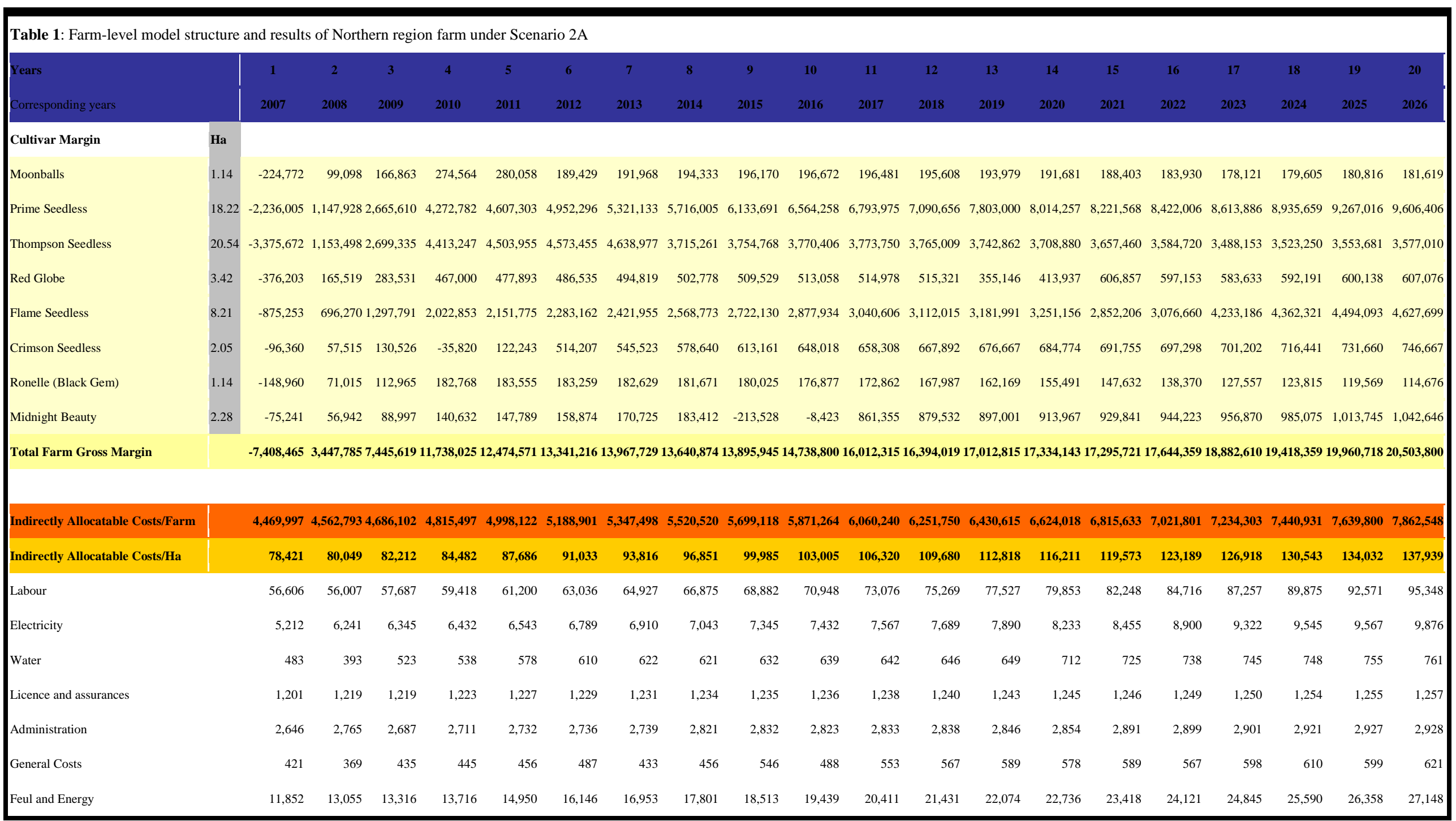




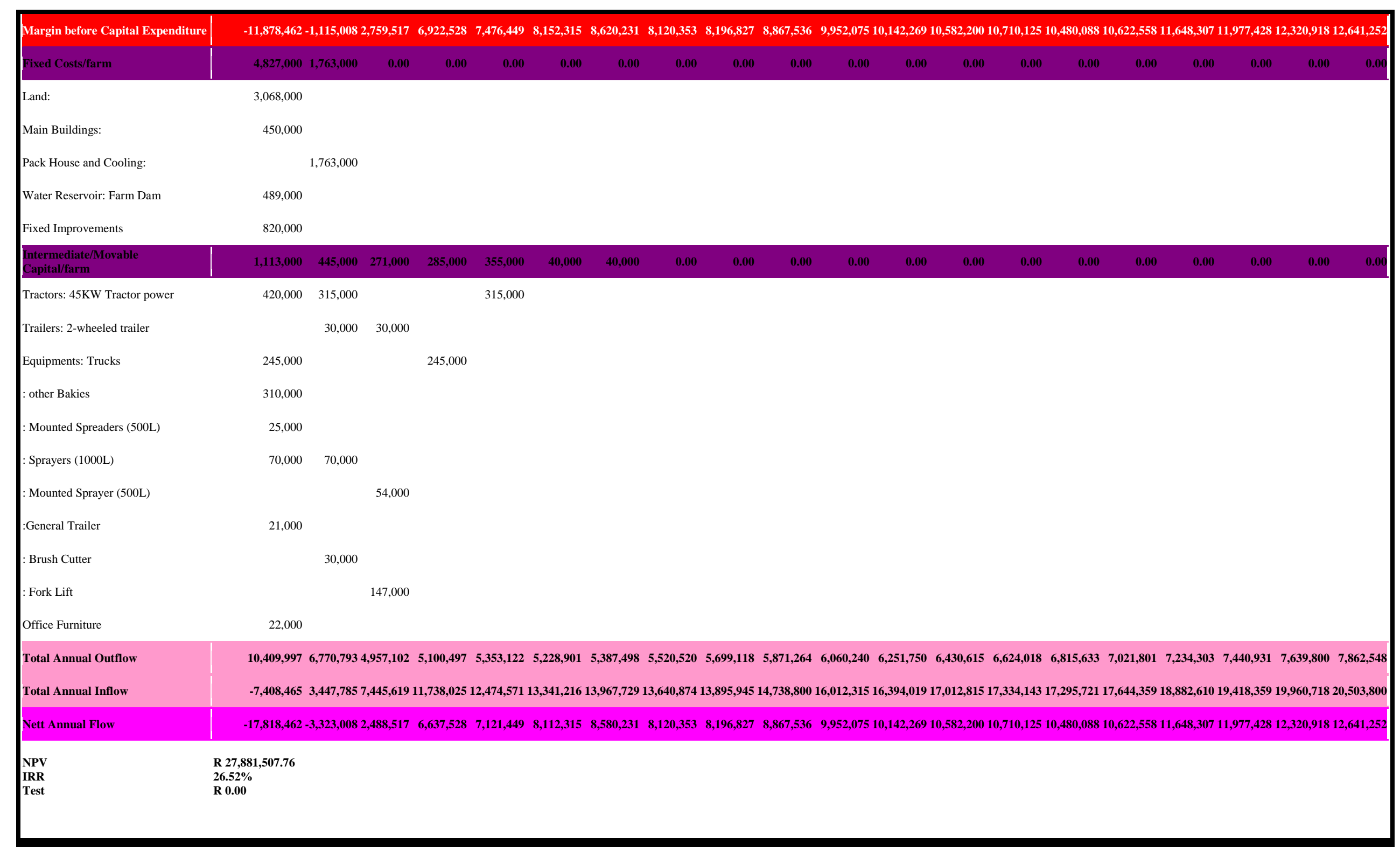




\section{Annexure G}

\section{Farm-level model structure and results of Western Cape farm under Scenario 2B}

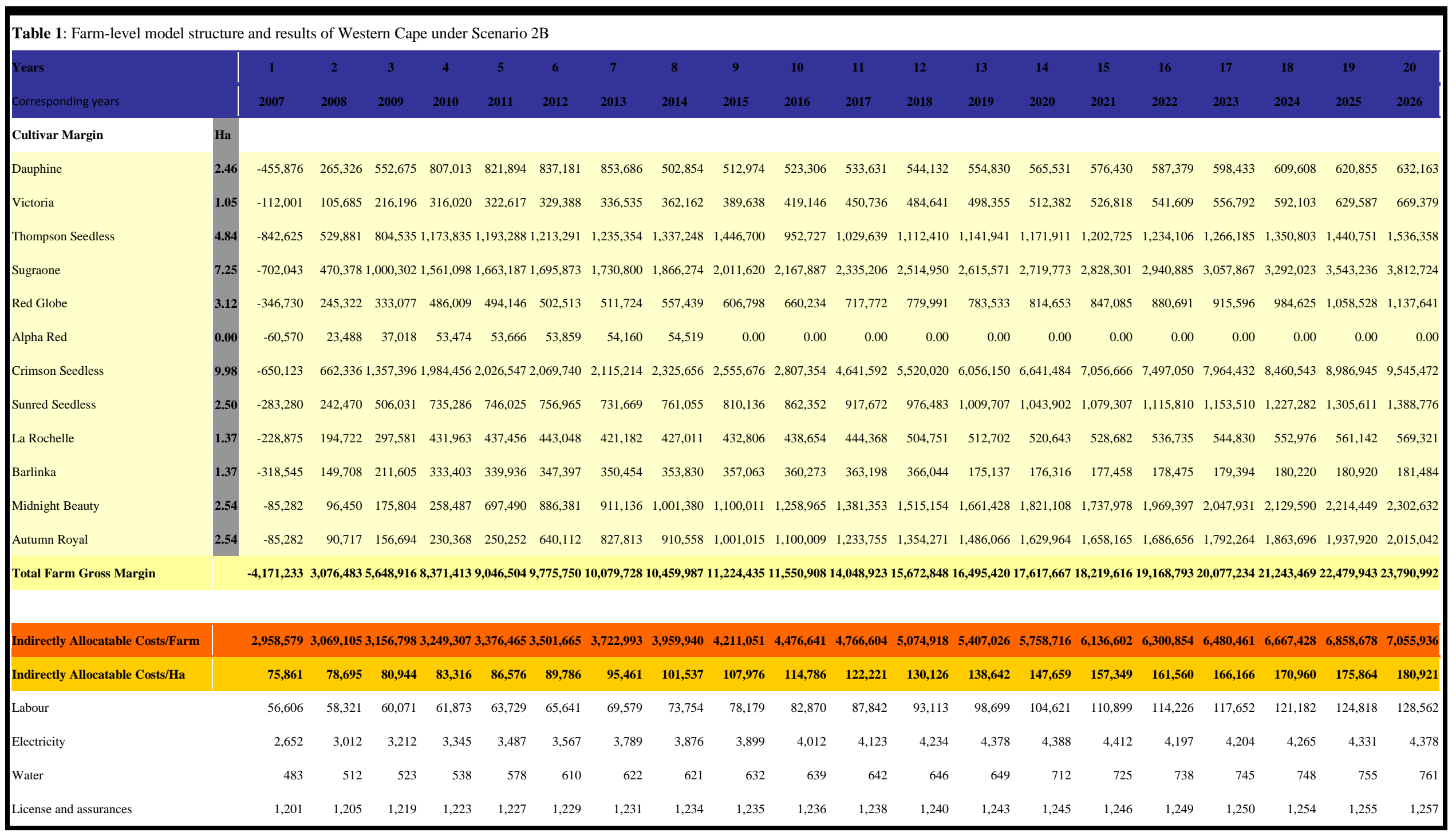




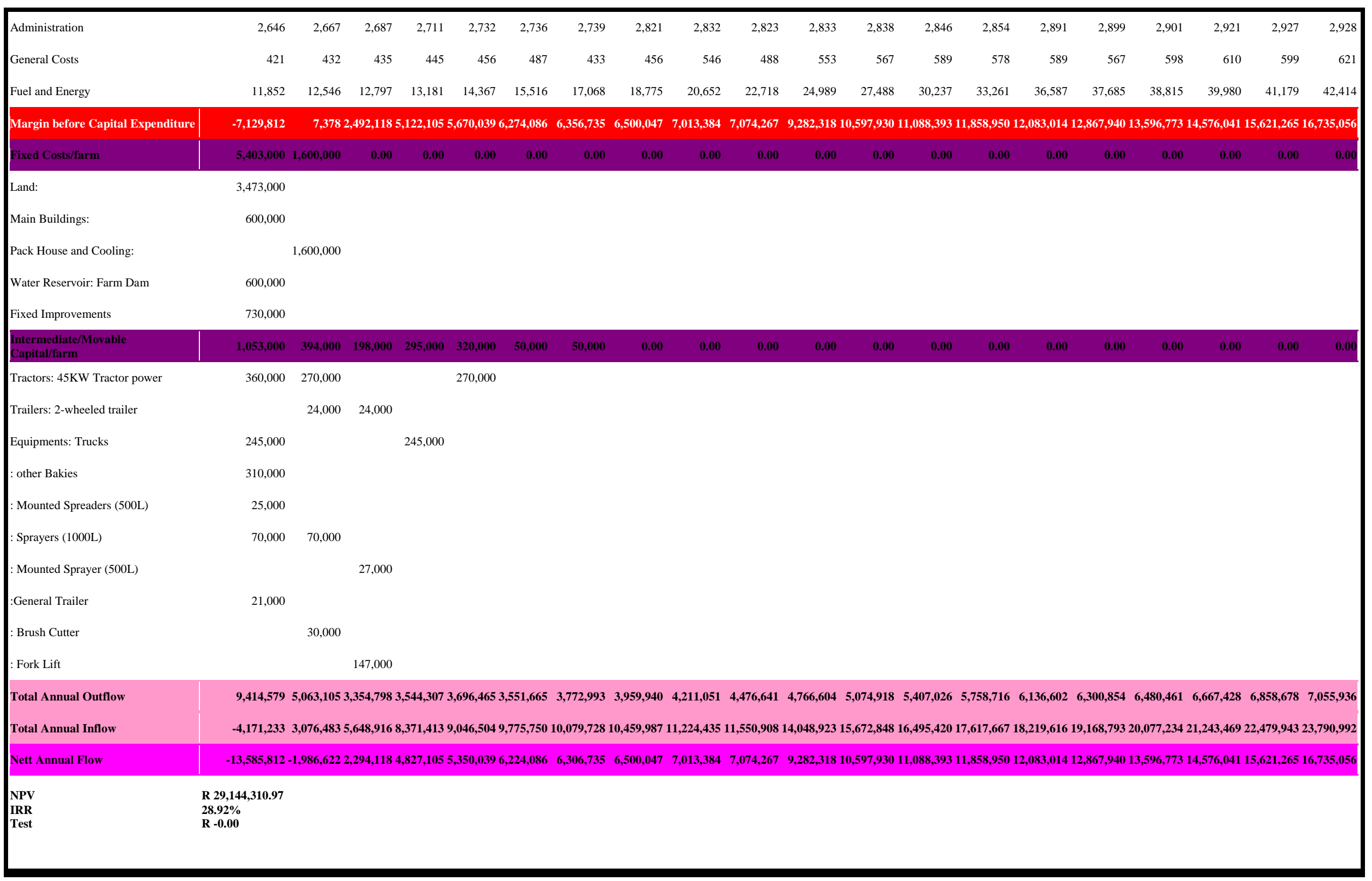




\section{Annexure H}

\section{Farm-level model structure and results of Northern Region farm under Scenario 2B}

\begin{tabular}{|c|c|c|c|c|c|c|c|c|c|c|c|c|c|c|c|c|c|c|c|c|c|}
\hline Years & & 1 & 2 & 3 & 4 & 5 & 6 & 7 & 8 & 9 & 10 & 11 & 12 & 13 & 14 & 15 & 16 & 17 & 18 & 19 & 20 \\
\hline Corresponding years & & 2007 & 2008 & 2009 & 2010 & 2011 & 2012 & 2013 & 2014 & 2015 & 2016 & 2017 & 2018 & 2019 & 2020 & 2021 & 2022 & 2023 & 2024 & 2025 & 2026 \\
\hline Cultivar Margin & На & & & & & & & & & & & & & & & & & & & & \\
\hline Moonballs & 0.00 & $-224,772$ & 99,098 & 166,863 & 274,564 & 0.00 & 0.00 & 0.00 & 0.00 & 0.00 & 0.00 & 0.00 & 0.00 & 0.00 & 0.00 & 0.00 & 0.00 & 0.00 & 0.00 & 0.00 & 0.00 \\
\hline Prime Seedless & 19.47 & $-2,236,0051$ & $1,147,928$ & $2,665,610$ & $4,272,782$ & $4,665,835$ & $5,078,141$ & $5,044,892$ & $5,764,892$ & $7,331,534$ & $7,942,740$ & $8,494,469$ & $8,745,389$ & $8,995,846$ & $9,247,874$ & $9,496,733$ & $9,739,337$ & $9,973,9301$ & $10,348,5371$ & 10,734,613 1 & $11,130,554$ \\
\hline Thompson Seedless & 15.30 & $-3,375,6721$ & $1,153,498$ & $2,699,335$ & $4,413,247$ & $4,571,795$ & $2,774,575$ & $2,858,809$ & $2,943,949$ & $3,025,396$ & $3,092,497$ & $3,154,049$ & $3,157,848$ & $3,151,973$ & $3,137,601$ & $3,110,572$ & $3,068,004$ & $3,008,039$ & $3,046,486$ & $3,081,827$ & $3,112,260$ \\
\hline Red Globe & 4.56 & $-376,203$ & 165,519 & 283,531 & 467,000 & 483,708 & 503,877 & 524,590 & 545,933 & 156,722 & 367,009 & 967,364 & 996,403 & $1,024,668$ & $1,052,635$ & 531,171 & $1,103,617$ & $1,125,500$ & $1,179,510$ & $1,235,549$ & $1,293,245$ \\
\hline Flame Seedless & 9.18 & $-875,253$ & 696,270 & $1,297,791$ & $2,022,853$ & $2,151,775$ & $2,338,942$ & $2,541,324$ & $2,760,366$ & $2,995,485$ & $2,623,099$ & $3,083,847$ & $4,834,353$ & $4,949,965$ & $5,097,153$ & $5,243,984$ & $5,389,049$ & $5,531,567$ & $5,741,353$ & $5,957,874$ & $6,180,427$ \\
\hline Crimson Seedless & 3.93 & $-96,360$ & 57,515 & 130,526 & 207,286 & 215,064 & 222,504 & 242,001 & $-473,459$ & $-96,640$ & $1,642,970$ & $1,778,585$ & $1,808,594$ & $1,860,868$ & $1,913,527$ & $1,965,616$ & $2,016,515$ & $2,065,871$ & $2,143,587$ & $2,223,702$ & $2,243,042$ \\
\hline Ronelle (Black Gem) & 1.14 & $-148,960$ & 71,015 & 112,965 & 172,710 & 176,062 & 178,466 & 180,676 & 182,703 & 184,191 & 184,334 & 183,773 & 182,518 & 180,497 & 177,794 & 174,100 & 169,198 & 162,947 & 163,976 & 164,718 & 165,038 \\
\hline Midnight Beauty & 3.42 & $-75,241$ & 56,942 & 88,997 & 140,632 & 147,789 & 162,919 & 179,462 & 197,567 & $-466,716$ & $-126,949$ & $1,472,273$ & $1,515,557$ & $1,558,727$ & $1,602,141$ & $1,644,963$ & $1,686,652$ & $1,726,897$ & $1,791,696$ & $1,858,469$ & $1,926,934$ \\
\hline Total Farm Gross Margin & & -7,408,465 3 & $3,447,785$ & $7,445,619$ & $11,971,0731$ & 12,412,030 1 & $11,259,425$ & $11,571,7541$ & $11,921,9501$ & $13,129,9731$ & $15,725,7001$ & $19,134,3592$ & $21,240,6622$ & $21,722,5442$ & $22,228,7262$ & 22,167,141 2 & $23,172,3722$ & $23,594,7502$ & $24,415,1442$ & $25,256,7532$ & $26,051,500$ \\
\hline $\begin{array}{l}\text { Indirectly Allocatable } \\
\text { Costs/Farm }\end{array}$ & & 4,469,997 4 & $4,562,793$ & $4,686,102$ & $4,815,497$ & $4,998,122$ & $5,188,901$ & $5,347,498$ & $5,520,520$ & $5,699,118$ & $5,871,264$ & $6,060,240$ & $6,251,750$ & $6,430,615$ & $6,624,018$ & $6,815,633$ & $7,021,801$ & $7,234,303$ & $7,440,931$ & $7,639,800$ & $7,862,548$ \\
\hline $\begin{array}{l}\text { Indirectly Allocatable } \\
\text { Costs/Ha }\end{array}$ & & 78,421 & 80,049 & 82,212 & 84,482 & 87,686 & 91,033 & 93,816 & 96,851 & 99,985 & 103,005 & 106,320 & 109,680 & 112,818 & 116,211 & 119,573 & 123,189 & 126,918 & 130,543 & 134,032 & 137,939 \\
\hline Labour & & 56,606 & 56,007 & 57,687 & 59,418 & 61,200 & 63,036 & 64,927 & 66,875 & 68,882 & 70,948 & 73,076 & 75,269 & 77,527 & 79,853 & 82,248 & 84,716 & 87,257 & 89,875 & 92,571 & 95,348 \\
\hline Electricity & & 5,212 & 6,241 & 6,345 & 6,432 & 6,543 & 6,789 & 6,910 & 7,043 & 7,345 & 7,432 & 7,567 & 7,689 & 7,890 & 8,233 & 8,455 & 8,900 & 9,322 & 9,545 & 9,567 & 9,876 \\
\hline Water & & 483 & 393 & 523 & 538 & 578 & 610 & 622 & 621 & 632 & 639 & 642 & 646 & 649 & 712 & 725 & 738 & 745 & 748 & 755 & 761 \\
\hline Licence and assurances & & 1,201 & 1,219 & 1,219 & 1,223 & 1,227 & 1,229 & 1,231 & 1,234 & 1,235 & 1,236 & 1,238 & 1,240 & 1,243 & 1,245 & 1,246 & 1,249 & 1,250 & 1,254 & 1,255 & 1,257 \\
\hline Administration & & 2,646 & 2,765 & 2,687 & 2,711 & 2,732 & 2,736 & 2,739 & 2,821 & 2,832 & 2,823 & 2,833 & 2,838 & 2,846 & 2,854 & 2,891 & 2,899 & 2,901 & 2,921 & 2,927 & 2,928 \\
\hline General Costs & & 421 & 369 & 435 & 445 & 456 & 487 & 433 & 456 & 546 & 488 & 553 & 567 & 589 & 578 & 589 & 567 & 598 & 610 & 599 & 621 \\
\hline $\begin{array}{l}\text { Margin before Capital } \\
\text { Expenditure }\end{array}$ & & 11, & $1,115,008$ & & & & & & & & & & 912 & 929 & 708 & 1,50816 & 0,5701 & 0,4471 & 7,2141 & 16,9521 & $18,188,952$ \\
\hline
\end{tabular}




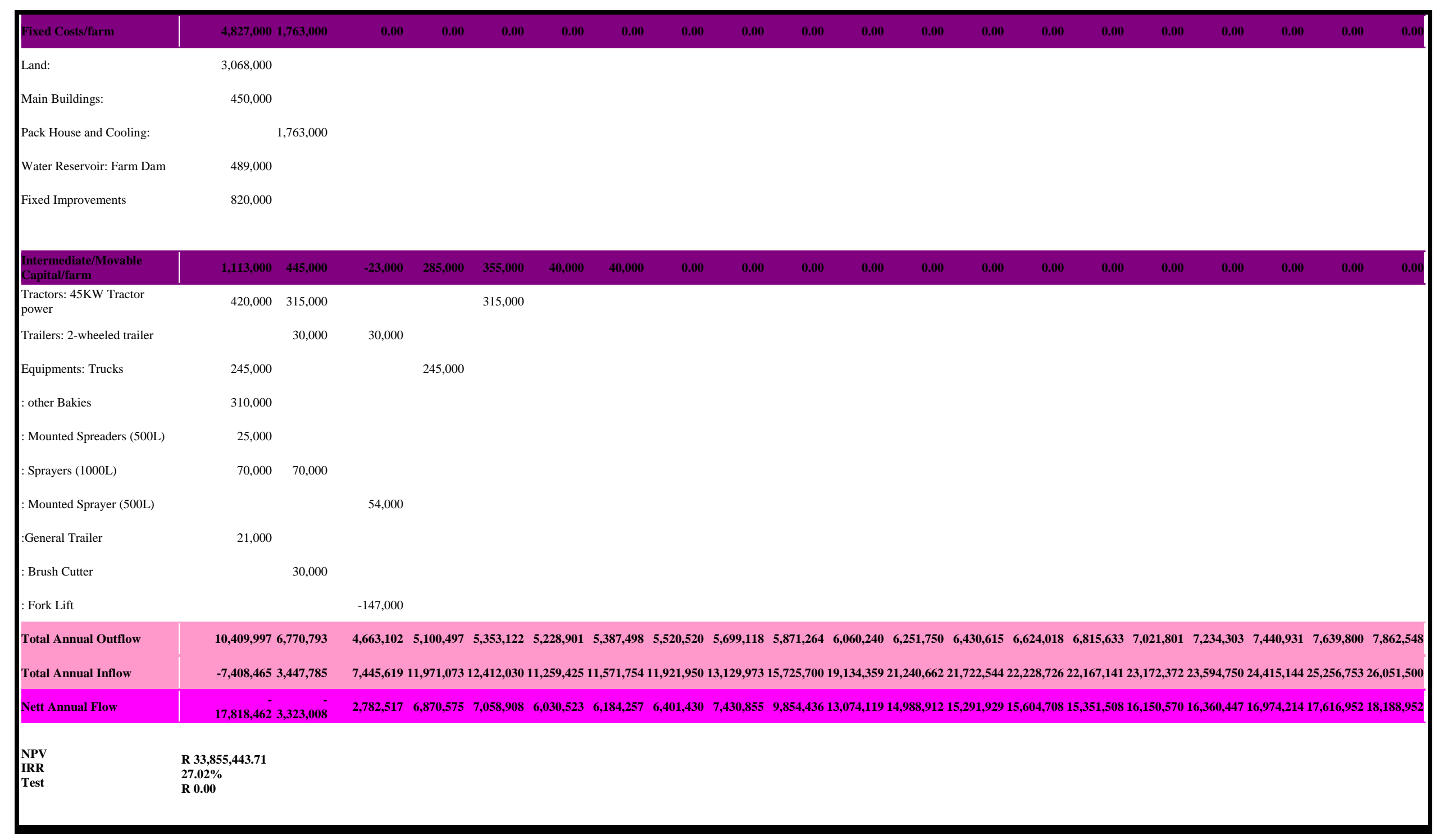


Annexure I

Sector Model Results

\begin{tabular}{|c|c|c|c|c|c|c|c|c|c|c|c|c|c|c|c|c|}
\hline & & & & & & & & & & & Western Cape & & Seasons & EU \& UK & Far East & $\begin{array}{l}\text { Middle } \\
\text { East }\end{array}$ \\
\hline Year & Seasons & is Volumes & Price & $\begin{array}{l}\text { Gross } \\
\text { Income }\end{array}$ & $\begin{array}{l}\text { Volume } \\
\text { Growth }\end{array}$ & $\begin{array}{l}\text { Price } \\
\text { Growth }\end{array}$ & Value Growth & Years & $\begin{array}{l}\text { Actual } \\
\text { Year }\end{array}$ & $\begin{array}{l}\text { egional } \\
\text { rice }\end{array}$ & Regional Price & \% Change & $06 / 07$ & $42,927,833$ & $34,545,300$ & 0 1,515,100 1,666,610 \\
\hline 2007 & 06/07 & $50,503,333$ & 355.60 & $2,807,816,989$ & $-1 \%$ & $26 \%$ & $24 \%$ & & 12007 & 65.0 & 46.2 & $0 \%$ & $07 / 08$ & $42,334,344$ & $4,482,460$ & $\begin{array}{ll}0 & 1,494,153 \\
1,643,56\end{array}$ \\
\hline 2008 & $07 / 08$ & $49,805,111$ & 169.80 & $3,476,168,482$ & $-3 \%$ & $-8 \%$ & $-11 \%$ & & 22008 & 79.3 & 60.3 & $30 \%$ & $08 / 09$ & $41,154,316$ & $64,357,516$ & $61,452,5051,597,756$ \\
\hline 2009 & $08 / 09$ & $48,416,842$ & 264.07 & $73,102,006,546$ & $1 \%$ & $2 \%$ & $4 \%$ & & 32009 & 74.7 & 53.5 & $-11 \%$ & $09 / 10$ & $41,648,167$ & 7 4,409,806 & 6 1,469,935 1,616,92 \\
\hline 2010 & $09 / 10$ & $48,997,844$ & 465.57 & $73,212,812,729$ & $1 \%$ & $2 \%$ & $3 \%$ & 4 & 2010 & 76.6 & 54.5 & $2 \%$ & $10 / 11$ & $42,147,945$ & $5,4,462,724$ & $41,487,5751,636,33$ \\
\hline 2011 & $10 / 11$ & $49,585,818$ & $8 \quad 67.00$ & $3,322,185,789$ & $1 \%$ & $2 \%$ & $4 \%$ & 5 & 2011 & 78.7 & 55.3 & $2 \%$ & $11 / 12$ & $42,653,721$ & $14,516,276$ & $61,505,4251,655,968$ \\
\hline 2012 & $11 / 12$ & $50,180,848$ & 868.63 & $3,443,694,115$ & $1 \%$ & $2 \%$ & $4 \%$ & 6 & 2012 & 80.7 & 56.5 & $2 \%$ & $12 / 13$ & $43,165,565$ & $5,4,570,472$ & $21,523,4911,675,840$ \\
\hline 2013 & $12 / 13$ & $50,783,018$ & 870.24 & $3,567,185,695$ & $1 \%$ & $2 \%$ & $4 \%$ & 7 & 2013 & 82.9 & 57.6 & $2 \%$ & $13 / 14$ & $43,683,552$ & $24,625,317$ & 7 1,541,772 1,695,95c \\
\hline 2014 & $13 / 14$ & $51,392,414$ & 471.99 & $93,699,589,691$ & $1 \%$ & $2 \%$ & $4 \%$ & 8 & 2014 & 85.1 & 58.9 & $2 \%$ & $14 / 15$ & $44,207,755$ & $54,680,821$ & $1 \quad 1,560,2741,716,30$ \\
\hline 2015 & $14 / 15$ & $52,009,123$ & 373.66 & 3,830,832,025 & $1 \%$ & $2 \%$ & $4 \%$ & 9 & 2015 & 87.3 & 60.0 & $2 \%$ & $15 / 16$ & $44,738,248$ & 8 4,736,991 & 1 1,578,997 1,736,897 \\
\hline 2016 & $15 / 16$ & $52,633,233$ & 375.49 & $3,973,376,722$ & $0 \%$ & $2 \%$ & $2 \%$ & 10 & 2016 & 89.6 & 61.4 & $2 \%$ & $16 / 17$ & $44,648,771$ & $14,727,517$ & 7 1,575,839 1,733,42 \\
\hline 2017 & $16 / 17$ & $52,527,966$ & 577.21 & $14,055,435,612$ & $-1 \%$ & $3 \%$ & $1 \%$ & 11 & 2017 & 92.0 & 62.4 & $2 \%$ & $17 / 18$ & $44,202,284$ & $4,6800,242$ & $21,560,0811,716,088$ \\
\hline 2018 & $17 / 18$ & $52,002,687$ & 779.14 & $4,115,717,922$ & $-1 \%$ & $2 \%$ & $1 \%$ & 12 & 2018 & 94.4 & 63.9 & $2 \%$ & $18 / 19$ & $43,760,261$ & $14,633,439$ & $91,544,4801,698,928$ \\
\hline 2019 & $18 / 19$ & $51,482,660$ & 80.93 & $3,166,327,817$ & $-1 \%$ & $2 \%$ & $2 \%$ & 13 & 2019 & 96.9 & 64.9 & $2 \%$ & $19 / 20$ & $43,541,460$ & $04,610,272$ & $21,536,7571,690,43$ \\
\hline 2020 & $19 / 20$ & $51,225,247$ & 782.85 & $4,244,212,468$ & $-1 \%$ & $2 \%$ & $1 \%$ & 14 & 2020 & 99.5 & 66.2 & $2 \%$ & $20 / 21$ & $43,106,045$ & $54,564,169$ & $91,521,3901,673,52$ \\
\hline 2021 & $20 / 21$ & $50,712,994$ & 484.88 & $4,304,360,280$ & $-2 \%$ & $2 \%$ & $0 \%$ & 15 & 2021 & 102.1 & 67.6 & $2 \%$ & $21 / 22$ & $42,243,924$ & $4,472,886$ & $61,490,9621,640,058$ \\
\hline 2022 & $21 / 22$ & $49,698,734$ & 486.93 & $34,320,531,587$ & $0 \%$ & $2 \%$ & $2 \%$ & 16 & 2022 & 104.8 & 69.0 & $2 \%$ & $22 / 23$ & $42,032,704$ & $4,450,522$ & $21,483,5071,631,858$ \\
\hline 2023 & $22 / 23$ & $49,450,241$ & 189.02 & $24,402,040,236$ & $-1 \%$ & $2 \%$ & $2 \%$ & 17 & 2023 & 107.6 & 70.4 & $2 \%$ & $23 / 24$ & $41,822,541$ & $14,428,269$ & 9 1,476,090 1,623,69 \\
\hline 2024 & $23 / 24$ & $49,202,989$ & 991.18 & 4,486,099,046 & $-1 \%$ & $2 \%$ & $2 \%$ & 18 & 2024 & 110.5 & 71.9 & $2 \%$ & $24 / 25$ & $41,613,428$ & $84,406,128$ & 8 1,468,709 1,615,58c \\
\hline 2025 & $24 / 25$ & $48,956,974$ & 493.42 & $2,573,546,446$ & $0 \%$ & $2 \%$ & $2 \%$ & 19 & 2025 & 113.4 & 73.4 & $2 \%$ & $25 / 26$ & $41,405,361$ & $14,384,097$ & 7 1,461,366 1,607,50? \\
\hline 2026 & $25 / 26$ & $48,712,190$ & 95.74 & $4,663,784,776$ & $3 \%$ & $-19 \%$ & $-17 \%$ & 20 & 2026 & 116.4 & 75.0 & $2 \%$ & Share & $85 \%$ & $9 \%$ & $3 \%$ \\
\hline Average & & $\mathbf{5 0 , 4 1 4 , 0 1 3}$ & 377.17 & 73,888,386,249 & $0 \%$ & $2 \%$ & $2 \%$ & $\begin{array}{l}\text { Regional Price } \\
\text { Growth }\end{array}$ & & $3 \%$ & & $2 \%$ & & & & \\
\hline
\end{tabular}




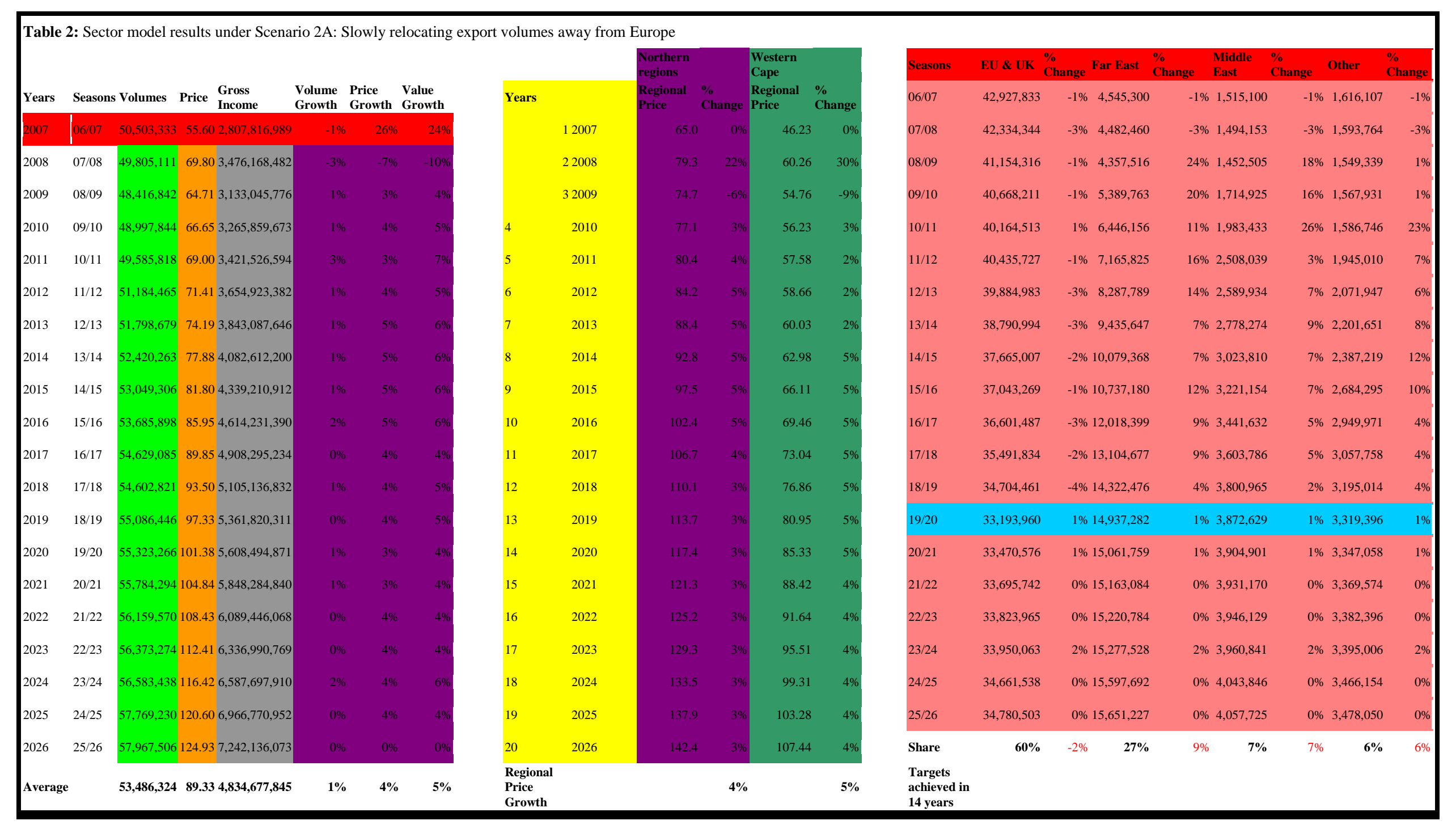




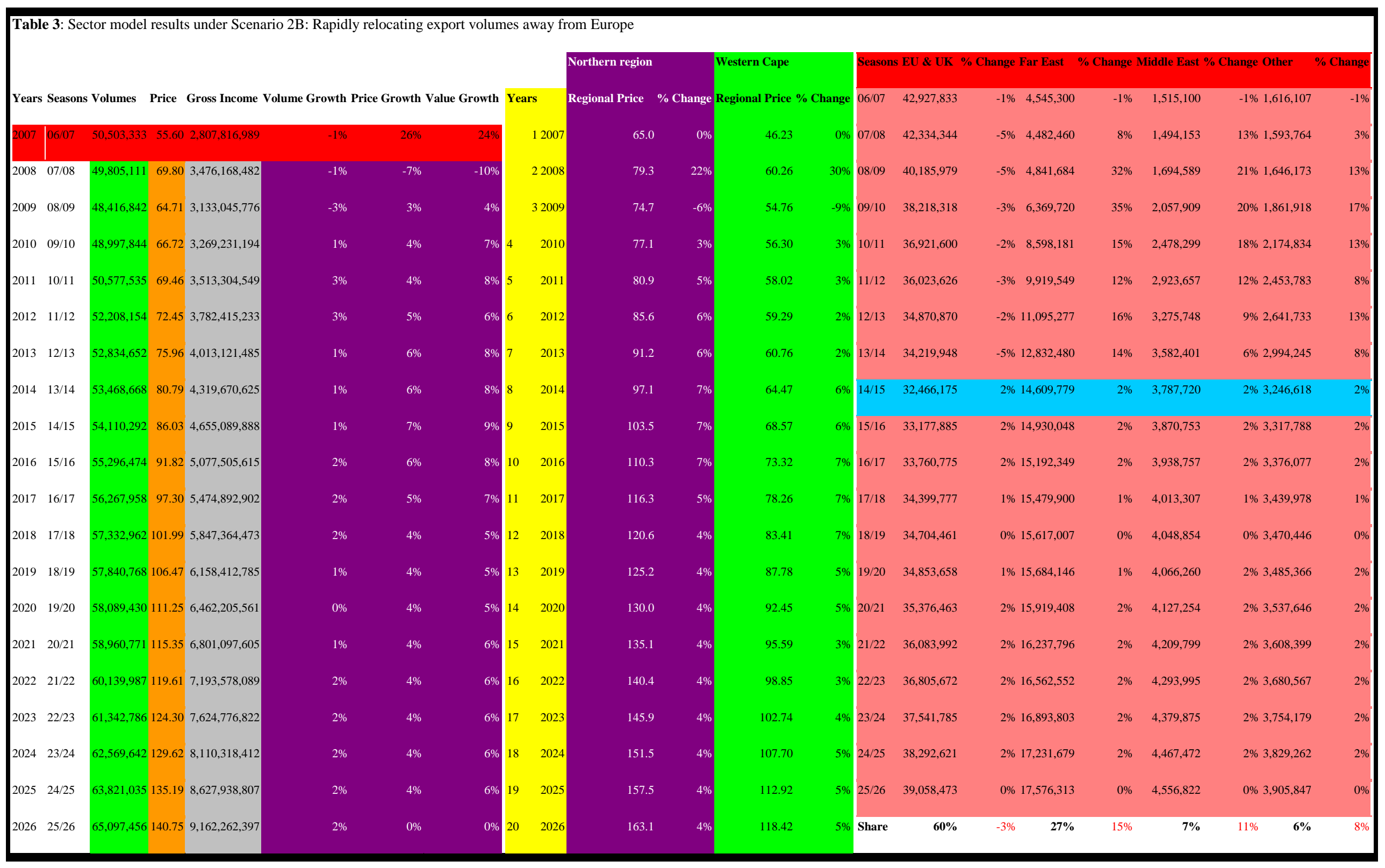


